\title{
Composition of Co-Rich Ferromanganese Crusts and Substrate Rocks from the NW Marshall Islands and International Waters to the North, Tunes 6 Cruise
}

by

\author{
James R. Hein ${ }^{1}$, Susan E. Zielinski ${ }^{1}$, Hubert Staudigel ${ }^{2}$, Se-Won Chang ${ }^{3}$ \\ Michelle Greene', and Malcolm S. Pringle ${ }^{4}$
}

Open File Report $97-482$

1997

${ }^{1}$ U.S. Geological Survey, Menlo Park, CA

${ }^{2}$ University of California, Scripps Institute of Oceanography, La Jolla, CA

${ }^{3}$ Korea Institute of Geology, Mining, and Materials, Taejon, Korea

${ }^{4}$ Scottish Universities Research and Reactor Centre, Kilbride, UK

This report is preliminary and has not been reviewed for conformity with the U.S. Geological Survey editorial standards or with the North American Stratigraphic Code. Any use of trade, product, or firm names is for descriptive purposes only and does not imply endorsement by the U.S. Government. 


\section{INTRODUCTION}

Thirteen northwest Pacific seamounts and guyots were dredged during the Tunes 6 cruise, which took place from 31 October to 2 December, 1991 aboard the R.V. Thomas Washington under the direction of $\mathrm{H}$. Staudigel. The primary objectives of the cruise were to study seamount ages and basalt chemistry in order to better understand the long term history of the South Pacific thermal anomaly (SOPITA). Representative ferromanganese oxyhydroxide crusts (Fe-Mn crusts) from most dredges were collected for this study, which extends our previous work on Fe-Mn crusts collected from the Marshall Islands and Federated States of Micronesia to seamounts located farther north (Hein, Kang et al., 1990; Hein, Ahn et al., 1992).

Most dredge recoveries were from 11 seamounts located in international waters north of the Marshall Islands Exclusive Economic Zone (EEZ), whereas only one seamount was sampled within the EEZ of the Marshall Islands (Fig. 1; Table 1). A total of 35 dredges were attempted and 23 recovered Fe-Mn crust samples and substrate rocks. One or two dredge hauls recovered samples from most guyots, however, Vlinder and Batiza Guyots yielded five and four dredge haul recoveries, respectively. Several guyots had previous bathymetric surveys (Batiza, Jennings, Maloney, Missy, Golden Dragon), or were crossed because they were close to the ship's track (Alcatraz, Bellevue) and therefore only minor additional bathymetric surveys were conducted during Tunes 6.

Most volcanic edifices studied are flat-topped guyots and many of those appear from seismic-reflection records to be devoid of summit reefs. However, Jennings Guyot yielded Cretaceous shallow-water limestone and five other guyots (mostly at the western end of the Marcus-Wake seamount group) yielded carbonates. Bellevue, Alcatraz, and Seth Guyots have steep and smooth upper flanks that are morphologically uniform to great depths, indicating carbonate thicknesses up to $1000 \mathrm{~m}$. Drowned atolls typically have steep upper flanks that slope at $24-36^{\circ}$ and the reefs form a $20-40 \mathrm{~m}$ rim around the summit platform. Vlinder Guyot has a volcanic cone projecting through the summit platform, indicating rejuvenation of volcanism. Guyots without limestones typically have summits that slope at low angles from a central high to the main break in slope between the summit and flanks. Below the main slope break, flanks slope at $12-20^{\circ}$ down to the abyssal seafloor.

This report presents data for those dredge hauls from which Fe-Mn crusts were studied. Data include sample descriptions, detailed chemical (major, minor, Pt-group, and rare earth elements) and mineralogical analyses of bulk Fe-Mn crusts and individual crust layers, and major oxide compositions and mineralogy for substrate rocks collected during the Tunes 6 cruise. Correlation coefficients are used to determine relationships between elements and Q-mode factor analysis to determine the grouping of elements with various crust phases.

\section{METHODS}

$\mathrm{X}$-ray diffraction was completed on a Philips diffractometer using Cuk $\alpha$ radiation and a curved-crystal carbon monochromator. Abundances of major oxides in substrate rocks were determined by X-ray fluorescence spectroscopy (Taggart et al., 1987), Fe(II) by colorimetric titration (Peck, 1964), $\mathrm{CO}_{2}$ by coulometric titration (Engleman et al., 1985), $\mathrm{H}_{2} \mathrm{O}+$ by water evolved at $925^{\circ} \mathrm{C}$ as determined coulometrically by Karl-Fischer titration (Jackson et al., 1987), and $\mathrm{H}_{2} \mathrm{O}-$ by sample weight difference at $110^{\circ} \mathrm{C}$ for greater than one hour (Shapiro, 1975). The low totals for the phosphorite samples occur because fluorine and sulfur were not determined and therefore are not included in the totals. High fluorine (to $4.4 \%$ ) and sulfur (to $2.1 \% \mathrm{SO}_{3}$ ) contents are typical of marine carbonate fluorapatite (Cullen and Burnett, 1986; Burnett et al., 1987; Hein et al., 1993). For Fe-Mn crusts, the concentrations of most major and minor elements were determined by inductively coupled 
plasma-atomic emission spectrometry, except those of $\mathrm{K}, \mathrm{Zn}$, and $\mathrm{Pb}$, which were determined by flame atomic-absorption spectroscopy, and those of $\mathrm{As}, \mathrm{Cr}$, and $\mathrm{Cd}$, determined by graphite-furnace atomic absorption spectroscopy on air-dried samples (Aruscavage et al., 1989). Concentrations of platinum-group elements (PGEs) and rare earth elements (REEs) for Fe-Mn crusts were determined by inductively coupled plasmamass spectrometry (Lichte et al., 1987a,b).

The usual Pearson product moment correlation coefficient was used to calculate the correlation coefficient matrices. For Q-mode factor analysis, each variable percentage was scaled to the percent of the maximum value before the values were row-normalized and cosine theta coefficients calculated. Factors were derived from orthogonal rotations of principal component eigenvectors using the Varimax method (Klovan and Imbrie, 1971). All communalities are $\geq 0.93$. Low factor scores, $\leq 10.21$, were discarded because they are not statistically significant.

\section{SUBSTRATE ROCK DESCRIPTIONS AND COMPOSITION}

Substrate rocks in decreasing order of abundance are basalt, breccia, phosphorite, hyaloclastite, limestone, volcaniclastic siltstone and sandstone, and mudstone (Table 1). As many as five different rock types were recovered in a single dredge haul. As seen in hand samples, breccias most commonly consist of basalt clasts in a hyaloclastite matrix, and/or carbonate fluorapatite (CFA) cement. Many samples have Mn oxide impregnations that commonly form dendrites. Volcanogenic clasts in breccias and volcaniclastic rocks are commonly replaced by clay minerals and iron oxides. Basalts are aphanitic with common plagioclase phenocrysts and CFA infilling fractures and vesicles. Some samples have vesicles filled with carbonate mud or Fe-Mn oxides. Reef limestones consist of rounded carbonate clasts with calcite cement and moldic porosity; pelagic limestones are micritic and bioturbated to massive. Mudstones are mostly bioturbated with Fe-Mn oxides lining some burrows. Phosphorites have carbonate mud in cracks and Fe-Mn oxide impregnations.

\section{X-ray Diffraction Mineralogy and Petrography}

Primary volcanogenic and sedimentary minerals include plagioclase, pyroxene, magnetite, and calcite; and secondary minerals include CFA, smectite, calcite, phillipsite, clinoptilolite, goethite, hematite, barite, and potassium feldspar (Table 2). Secondary CFA is the most abundant mineral in these samples and occurs in $73 \%$ of the samples as a major or moderate constituent, regardless of rock type (Table 2).

Hyaloclastite and hyaloclastite breccias consist chiefly of CFA and phillipsite (Table 2), with moderate to minor amounts of plagioclase, pyroxene, and magnetite. Most samples contain minor amounts of smectite. One sample consists predominantly of goethite. Hyaloclastites are predominantly completely altered to phillipsite, clinoptilolite, smectite, and $\mathrm{Fe}$ oxides, which in turn are cemented by CFA and/or replaced in varying degrees by CFA. Consequently, all gradations exist from altered hyaloclastite to phosphorite with relict hyaloclastite textures. Vesicles are lined with smectite and infilled by zeolites.

Mineralogically, most basalts consist chiefly of plagioclase and pyroxene, although some contain large amounts of CFA, hematite, and goethite. One sample (D21-2) is almost completely replaced by goethite and hematite, whereas another sample (D38-2) is nearly completely replaced by CFA, but shows a relict basalt microcrystalline texture. A wide range of basalt types were collected with variable amounts and combinations of plagioclase, pyroxene, olivine, and rarely amphibole phenocrysts. Groundmass textures include holocrystalline, subophitic, intersertal, microcrystalline, aphanitic, and doleritic. Samples range from highly vesicular to massive. Detailed descriptions of the basalts are available from H. Staudigel, Scripps Institution of Oceanography (see also Koppers, 1997). 
Rocks identified as limestones from hand samples are overwhelmingly CFA mineralogically, with moderate amounts of plagioclase, calcite, barite, phillipsite, and potassium feldspar and trace amounts of chlorite, smectite, and quartz. Calcite is primary and the other minerals are due to various admixtures of volcanogenic grains and their alteration products, or to cementation and replacement. Barite forms veins and lenses. All gradations exist from unaltered limestone to phosphorite with relict limestone textures, especially CFA-replaced foraminiferal sands, some with abundant relict radiolarians.

Three types of mudstones were sampled from this region. The first type is composed mainly of magnetite, hematite, and smectite with lesser amounts of phillipsite and clinoptilolite. The second type of mudstone consists of variable amounts of CFA, potassium feldspar, smectite, phillipsite, and plagioclase, whereas the third type is composed solely of smectite. The first type is most likely either an altered ash or altered fine-grained hyaloclastite. The second type is a CFA-replaced altered volcaniclastic mudstone and the third type is bentonite.

Phosphorites are composed of CFA with plagioclase, smectite, and other minerals (Table 2). CFA commonly cements all of the clastic rock types and variably replaces grains in all rock types from incipient to complete replacement. The most commonly replaced rock type is pelagic limestone, where the foraminifera, radiolarians, other grains, and presumably the nannofossil matrix have been completely replaced by CFA. The grains (except the nannofossils) occur as ghosts. Barite veins and lenses commonly occur in the phosphatized pelagic limestone. In addition, shallow-water limestone, volcaniclastic rocks, hyaloclastite, and rarely basalt are completely replaced by CFA, thereby forming phosphorite.

\section{Chemistry}

The most $\mathrm{P}_{2} \mathrm{O}_{5}$ rich CFA-replaced sedimentary rocks have $\mathrm{CaO} / \mathrm{P}_{2} \mathrm{O}_{5}$ ratios of 1.60 to 1.66 (Table 3), whereas theoretical chemical compositions for CFA range from 1.5 to 1.6 (Manheim and Gulbrandsen, 1979). The slight excess Ca over P in some of our samples is due to additional $\mathrm{Ca}$ associated with minor contamination by volcanogenic plagioclase, phillipsite cement (an alteration product of volcanic debris), and to relict calcite in the phosphatized limestone.

Smectite occurs in major to moderate amounts in $29 \%$ of the samples analyzed, and is especially abundant in the mudstones. It is found in at least trace amounts in over $70 \%$ of the samples analyzed. The one sample of nearly pure smectite (D33-3) has relatively high $\mathrm{Al}, \mathrm{Fe}$, and $\mathrm{Mg}$ contents and low $\mathrm{Ca}$ content, indicative of an iron-rich montmorillonite.

Phillipsite is also a common mineral, occurring in major to moderate abundances in $26 \%$ of the samples, primarily in the breccias and phosphatized limestones. The samples measured for chemistry, which have abundant phillipsite, have $\mathrm{Si} / \mathrm{Al}$ ratios ranging from 3.0 to 3.4, which is higher than the range for most marine phillipsites (2.3-2.8) and significantly higher than the values for mafic igneous rocks (1.3-2.4; Kastner, 1979). These high values are the result of contamination by Si-rich volcanogenic and other phases.

Most of the basalt and basalt clasts in breccia are altered to smectite and goethite and are rarely replaced by phosphorite and phillipsite. Alteration is best characterized by increases in $\mathrm{Fe}_{2} \mathrm{O}_{3}$ and water and decreases in $\mathrm{FeO}$ and $\mathrm{K}_{2} \mathrm{O}$ contents (Table 3). Volcaniclastic mudstones and hyaloclastites have compositions comparable to highly altered basalts.

\section{FERROMANGANESE CRUSTS}

Fe-Mn crusts studied here vary in thickness from 3 to $114 \mathrm{~mm}$ (Tables 1, 4), although crusts were collected during Tunes 6 that range from a patina to $200 \mathrm{~mm}$ or more (D18, 
South Wake Guyot). The thickest crust studied $(114 \mathrm{~mm})$ was dredged from the western flank of Vlinder Guyot in dredge D27. The thickest crust average from the various dredge hauls is $49 \mathrm{~mm}$ collected from Neen Koiaak Guyot in dredge D12. Limited availability of personnel on the Tunes 6 cruise did not allow for detailed records to be kept of maximum and average crust thicknesses for each dredge and the values listed in this report are predominately for samples analyzed here and from sketchy notes in the original logs.

Thicker crusts are composed of two or more layers, six being the maximum and two being the most common. Polished thin sections show that various layers are typically botryoidal, columnar, mottled, and laminated, in that order of abundance and are typical of other central Pacific crusts (Hein et al., 1992a). If the substrate rock has an irregular surface, then the first Fe-Mn oxyhydroxide layer is botryoidal, with initial points of growth being on the projections. If the substrate rock has a smooth surface, the first oxyhydroxide layer may be laminated, massive, or mottled. Mottled layers are porous and commonly have the most contamination by detrital minerals relative to the other layer types. Detrital minerals also accumulate between columns and are the chief cause for the directed growth of the columnar structure.

\section{Growth Rates and Ages}

Because the flux of $\mathrm{Co}$ into $\mathrm{Fe}-\mathrm{Mn}$ crusts is relatively constant over time, growth rates can be determined from the Co content using the equation of Puteanus and Halbach (1988):

$$
\text { Growth Rate }(\mathrm{mm} / \mathrm{Ma})=1.28 /(\mathrm{Co} \%-0.24)
$$

The faster a crust grows, the lower the Co concentration. Crusts in which the older parts have been heavily phosphatized ( $>1$ weight $\% \mathrm{P})$, however, do not have such a simple relationship because $\mathrm{P}$ dilutes the $\mathrm{Co}$ and likely mobilizes many of the metals within that older crust generation (Hein, Kang, et al., 1990; Koschinsky and Halbach, 1995). Growth rates in phosphatized parts of crusts may be determined using $\mathrm{Co}, \mathrm{Mn}$, and $\mathrm{P}$ contents and another set of equations of Puteanus and Halbach (1988):

$$
\begin{aligned}
& \mathrm{Co}^{(\mathrm{x})^{\prime}}=\mathrm{Co}(\mathrm{x}) \mathrm{m}\left(\mathrm{Mn} / \mathrm{Co}^{(\mathrm{x})}\right) /\left(\mathrm{Mn} / \mathrm{Co}^{(\mathrm{b})}\right) \\
& \mathrm{Co}(\mathrm{x})^{\prime \prime}=\mathrm{Co}^{(\mathrm{x})}(1-0.05 \Delta \mathrm{P})^{-1}
\end{aligned}
$$

where $\mathrm{Co}^{(\mathrm{x})^{\prime}}$ is the Co concentration corrected for phosphate dilution; $\mathrm{Co}(\mathrm{x}) \mathrm{m}$ is the Co concentration measured in layer $(\mathrm{x}) ; \mathrm{Mn} / \mathrm{Co}^{(\mathrm{x})}$ and $\mathrm{Mn} / \mathrm{Co}^{(\mathrm{b})}$ are the $\mathrm{Mn} / \mathrm{Co}$ ratios measured in layer ( $\mathrm{x}$ ) and the boundary layer, respectively; $\triangle \mathrm{P}$ is the difference between the CFA fraction of layer (x) and the average of the younger crust; and $\mathrm{Co}(\mathrm{x}) "$ is the doubly corrected Co concentration in layer (x). Based on Co content for samples with less than one weight percent $\mathrm{P}$ and based on $\mathrm{Co}, \mathrm{P}$, and $\mathrm{Mn}$ contents for the remaining crust samples, growth rates for bulk crusts varied from $2.1 \mathrm{~mm} / \mathrm{Ma}$ to $9.8 \mathrm{~mm} / \mathrm{Ma}$ (Table 4). The average growth rate for bulk crusts was $5.0 \mathrm{~mm} / \mathrm{Ma}$, which is within the range of growth rates for hydrogenetic crusts (Hein et al., 1987b; 1990), but is a somewhat faster mean rate than for crusts from areas to the south and southeast. Growth rates for Tunes 6 crusts generally decrease with decreasing latitude, with the highest growth rates calculated for crusts from Oma Vlinder and Missy Guyots. Individual crust layers grew at rates from 2.2 to 14.3 $\mathrm{mm} / \mathrm{Ma}$.

The five thickest crusts analyzed, D27-5 (114 mm), D15-4 (95 mm), D 36-3 (81 mm), D25-3 (80 mm), and D41-1 (73 mm) began growing at 24.4, 37.5, 21.5, 15.8, and 13.0 Ma respectively, based on the growth rates of individual layers and the thickness of each 
layer (Table 4). These ages of initiation of crust growth are minimum ages because the technique does not take into account dissolution and erosional unconformities which can add another several million years to the age of the crusts (Futa et al., 1988; Ingram et al., 1990; Ling et al., 1997). The oldest crust, from Aean Kan Guyot, is of late Eocene age (37.5 Ma), but is still 37-67 Ma younger than ages typical of central Pacific Cretaceous seamounts.

\section{X-ray Diffraction Mineralogy}

Great care was taken in sampling crusts for chemical and mineralogical analyses. All contamination from recent sediments was removed, which was especially critical in porous crust layers. Also, special attention was paid to obtaining a clean separation of the lower crust layers from the substrate. Any minerals or elements determined to exist in the various crust layers were incorporated into those layers during deposition or diagenesis and are not due to sampling procedures or post-depositional infiltration of sediment. Finally, all encrusting organisms and other debris were cleaned from the crust surfaces before sampling. Bulk always refers to the entire crust thickness, whether composed of layers or not.

All but two of the 79 samples of Fe-Mn crusts contain greater than $90 \% \delta-\mathrm{MnO}_{2}$ (vernadite; Table 5), which has only two X-ray reflections at about $2.42 \AA$ and $1.41 \AA$. Xray amorphous $\mathrm{Fe}$ oxyhydroxide epitaxially intergrown with the $\delta-\mathrm{MnO}_{2}$ is also a dominant phase in these crusts, but is not included with the crystalline phases listed in Table 2. This X-ray amorphous iron phase crystallized to goethite in three of the bulk crusts and two of the individual layers analyzed. In the individual layers, goethite was present only in the innermost layer, indicating that those layers have undergone the most advanced diagenetic alteration. Two more samples, one an innermost layer (D41-1C) and the other a thin bulk crust (D14-17A), contain hematite, which is likely due to contamination by altered volcanogenic debris in the thin bulk crust, but may instead be due to diagenesis in the inner layer of the thick crust. CFA occurs in $24 \%$ of the bulk crusts and $19 \%$ of the layers analyzed. Layered samples contain up to $19 \%$ CFA, always within the innermost one or two layers of the crust. CFA is not found in the outer layers.

Quartz was found in all but three crusts. Of those samples that contain quartz, all but five have three percent or less quartz, whereas the other five have 4-5\% quartz. Plagioclase (trace to $5 \%$ ) was found in $75 \%$ of the samples. The quartz and some of the plagioclase are of eolian origin, carried by the westerlies from Asia, as there is no local or regional source for quartz in the west-central Pacific. The Marshall Islands are south of the main westerly wind belt which is reflected in lower quartz contents compared to crusts from higher latitudes (Hein et al., 1985a,b; 1987a; 1990). The remainder of the plagioclase, as well as the phillipsite, pyroxene, and calcite are reworked from local outcrops and incorporated into the crusts during precipitation of the Fe-Mn oxyhydroxides.

Calcite occurs in trace amounts in only two bulk samples of thin crusts and none of the layers. Calcite probably occurs from incorporation of biogenic calcite in the outermost millimeter of those crusts during accretion of the oxyhydroxides. The calcite is replaced by the oxyhydroxides once the incorporated calcite is buried by accretion of additional layers.

Todorokite is rare in hydrogenetic seamount crusts (Hein et al., 1987a), but occurs questionably in one of the samples analyzed here (D15-1B, Aean-Kan Guyot). Todorokite may form under different redox conditions than the more oxidized $\delta-\mathrm{MnO}_{2}$ phase, either during initial precipitation, during diagenesis, or during low-temperature hydrothermal precipitation. A diagenetic origin for D15-1 todorokite is unlikely because the crust is too thin for significant diagenesis. 


\section{Chemistry}

Bulk Crusts: Chemical analyses for 84 samples and subsamples of crusts are presented in Tables 6 and 7 (normalized to $0 \% \mathrm{H}_{2} \mathrm{O}^{-}$). General statistics for each dataset are presented in Tables 8, 9, and 10.

Water-normalized contents are often used because hygroscopic water varies with humidity in the lab in which samples are analyzed. Therefore, $\mathrm{H}_{2} \mathrm{O}^{-}$, and consequently the abundances of other elements, will vary accordingly and significantly as hygroscopic water contents can be as high as $30 \%$. Compositions normalized to $0 \% \mathrm{H}_{2} \mathrm{O}^{-}$(Table 7) can be more meaningfully compared and may also more closely represent the grade of the potential ore. Consequently, the following discussion is based on hygroscopic water-free data.

The mean $\mathrm{Fe}$ and $\mathrm{Mn}$ contents of the 46 bulk crust samples are $16.7 \%$ and $22.1 \%$, respectively (Table 9). The mean Fe/Mn ratio (0.76) is comparable to the mean ratio for the entire central Pacific region ( 0.77 ; Hein et al., 1992b), but is somewhat higher than the mean ratio for the Marshall Islands EEZ (0.65; Hein, Kang, et al., 1990). Mean Fe content is less and $\mathrm{Mn}$ somewhat less compared to bulk crust samples from the Marshall Islands EEZ, $15.3 \%$ and $23.6 \%$, respectively. The mean contents of the economically important metals $\mathrm{Co}(0.52 \%), \mathrm{Ni}(0.40 \%)$, and $\mathrm{Pt}(0.50 \mathrm{ppm})$ are somewhat less than the Marshall Islands EEZ mean contents of $0.66 \%, 0.50 \%$, and $0.58 \mathrm{ppm}$, respectively. The mean Co content is less, $\mathrm{Ni}$ about the same, and $\mathrm{Pt}$ much higher than mean contents for the equatorial Pacific. Phosphorus, a potential byproduct for mining, has a low mean value of $0.72 \%$ compared to the central Pacific mean of more than $1 \%$ and the Marshall Islands EEZ mean of nearly $2 \%$.

Analysis of a large number of thick crusts lowers the mean contents of most metals (except platinum), and that is probably why this study shows mean concentrations below the regional and Marshall Islands means. Studies that include only analyses of thin crusts yield mean concentrations higher than those of regional means (for example, Pichocki and Hoffert, 1987; see Hein et al., 1992b for discussion).

Layers: In general, Co contents decrease from the outer surface to the substrate through Fe-Mn crusts (Halbach et al., 1982; Hein et al., 1985b); but in Tunes 6 samples, only about half show that decrease (Tables 6,7), whereas in the other half Co increases with depth; in one sample, the Co content remains unchanged with depth in the crust. This geographic area is unique in having so many samples that show an increase in Co with depth in the crusts. Other elements also change with depth in the crusts. Although there are exceptions, the following changes typically occur with depth in the Tunes 6 crusts: $\mathrm{Fe}$, $\mathrm{Si}, \mathrm{Al}, \mathrm{Pb}, \mathrm{Cr}$, and $\mathrm{As}$ decrease, while $\mathrm{Mn}, \mathrm{Ni}, \mathrm{Cu}, \mathrm{Zn}, \mathrm{Ba}, \mathrm{Ce}$, and $\mathrm{Pt}$ increase.

Those trends indicate that, in general, elements representative of the aluminosilicate detrital fraction decrease toward the substrate (with notable exceptions), in contrast to the trend found in other studies. This decreasing trend with depth in the crusts is also true for the Fe oxyhydroxide phase and associated elements, whereas the Mn oxyhydroxide phase and associated elements show the opposite trend. Most of the PGEs increase toward the substrate, which is typical of the trend observed in other studies. Phosphorus remains relatively constant in thin crusts and increases significantly in the lower layers of thick crusts. Strongly phosphatized crusts disrupt the trends in the elements as noted above. A few crusts have the highest concentrations of elements in one of the internal layers.

Thinner crusts are similar chemically to the outer parts of thicker crusts. Thinner crusts $(<15 \mathrm{~mm}$ ) have less $\mathrm{Mn}$ and $\mathrm{Co}$ than thicker crusts and significantly less $\mathrm{P}, \mathrm{Cu}, \mathrm{Mo}$, and $\mathrm{Ni}$, but more $\mathrm{Fe}$ than thicker crusts. These trends are similar to those reported by Hein, Ahn, et al. (1992) for Micronesian crusts, but contrast with trends in crusts from other areas. These differences probably are related to milder phosphatization of Tunes 6 crusts compared to those from other areas. Phosphatization dilutes these elements with depth in the crusts, making their overall grades lower than for thinner, non-phosphatized crusts. In addition to those element trends, thin crusts have higher $\mathrm{Al}, \mathrm{Si}, \mathrm{K}$, and $\mathrm{Cr}$ and much lower 
Pt concentrations than thick crusts. The Pt contents of two inner layers of thick crusts are extremely high, among the highest measured in any Pacific crusts, $2.1 \mathrm{ppm}$ (D25-3D) and $2.7 \mathrm{ppm}(\mathrm{D} 32-9 \mathrm{H})$. The other PGEs are also very high in these crust layers.

\section{Platinum Group Elements (PGEs)}

We report the concentrations of $\mathrm{Pt}, \mathrm{Pd}, \mathrm{Rh}, \mathrm{Ru}$, and Ir for 19 bulk crusts and 33 crust layers (Tables 6, 7). This is the fourth report of $\mathrm{Ru}$ and $\mathrm{Ir}$ contents in Fe-Mn crusts (see Hein, Kang, et al., 1990; Hein, Ahn, et al., 1992; Hein, Gramm-Osipov, et al., 1994). Platinum contents vary from $0.133 \mathrm{ppm}$ to $0.874 \mathrm{ppm}$ for bulk crusts and from $0.133 \mathrm{ppm}$ to $2.65 \mathrm{ppm}$ for crust layers (Tables 9,10 ). Palladium is below the limit of detection of 4 $\mathrm{ppb}$ (based on the original hygroscopic water-bearing dataset); the other PGEs vary by factors of three to nine: $\mathrm{Rh}(9.8-97.6 \mathrm{ppb}), \mathrm{Ru}(8.7-32.3 \mathrm{ppb})$, and $\operatorname{Ir}(4.1-22.3 \mathrm{ppb})$. The maximum values for each PGE (except Pd) are extremely high compared to those in other crusts analyzed to date. However, the mean values of bulk crusts are significantly less than mean values of Marshall Islands EEZ crusts for Ir, somewhat less for Pt and Rh, and somewhat more for Ru. The Tunes 6 PGE contents are significantly enriched over lithospheric and seawater abundances, but not over chondrite abundances (Figs. 2, 3; Parthé and Crocket, 1978; Hodge et al., 1986; Goldberg, 1987; Anders and Grevesse, 1989; Colodner, 1991; Bertine et al., 1993). For comparison, the sample with the highest PGE enrichment (D32-9H, layer 50-60 mm) is plotted in Fig. 3. Relative to chondrites, Ir and $\mathrm{Ru}$ ratios are a few times greater in $\mathrm{D} 32-9 \mathrm{H}$ compared to the mean values for bulk crusts, $\mathrm{Rh}$ an order of magnitude greater, and Pt is enriched by three orders of magnitude. Relative to surface seawater, Ir is the most enriched for the mean bulk crust dataset, whereas Pt is the most enriched for sample D32-9H, but only somewhat more enriched than Ir, Ru, and Rh. Pd probably has about the same enrichment for both mean crust and most enriched crust datasets.

The highest Pt, Rh, and Ir concentrations occur in the inner layer of crust D32-9H, which was recovered from the deepest water dredge site, whereas the highest Ru content is in the innermost layer of crust D18-1C. Enrichment of PGEs in the inner parts of crusts is common for central Pacific crusts. The highest $\mathrm{Pd}$ and $\mathrm{Ru}$ concentrations occur in crusts from the Yap and Mariana arcs, as do other elements indicative of clastic input. As shown in previous studies, $\mathrm{Pt}$, Ir, and $\mathrm{Rh}$ are derived predominantly from seawater, whereas $\mathrm{Pd}$ and much of the $\mathrm{Ru}$ are derived from clastic debris, the remainder of the Ru being derived from seawater. The extraterrestrial component (meteorite debris) in the bulk crusts is small. However, meteorite debris may be concentrated locally in the crusts by formation of dissolution unconformities, or by proximity of the crust to meteorite fallout during formation of the layer. Localized extraterrestrial debris-rich horizons, however, do not alter the overall hydrogenetic signature of the PGEs in the crusts. The high Pt contents in three crusts studied here occur over many millimeters of the inner crusts, which represent millions of years of accretion of Fe-Mn oxyhydroxides and therefore cannot be explained as the result of meteorite impacts, as those are essentially instantaneous events and would form only a very thin lamina in the crusts. In addition, the PGE ratios are non-chondritic, with Fe-Mn crust compositions showing more than an order of magnitude more Pt relative to $\mathrm{Ir}$ and $\mathrm{Rh}$ relative to Ir. More likely, $\mathrm{Pt}$ is a redox sensitive element and its changing concentration reflects changing redox conditions and diagenesis (see Hein et al., 1997).

\section{Rare Earth Elements (REEs)}

The concentrations of REEs are reported for 19 bulk crust samples and 33 individual crust layers (Table 11 ). For bulk crusts, $\Sigma$ REEs range from $0.13 \%$ to $0.32 \%$, with a mean 
of $0.21 \%$. Nearly the same range is found for individual layers $(0.14-0.35 \%)$ (Table 11$)$. Out of 13 samples in which layers were analyzed, 11 of those show increases of $\Sigma R E E s$ with depth in the crusts; the other two samples show the opposite trend although the differences in percentages of $\Sigma$ REEs between layers is quite small in those two samples. For crusts D18-1, D23-1, D37-4, and D41-1, the outer layer of each crust has the highest concentration of each REE, except $\mathrm{Ce}$, which is highest in the middle layer. This is the same trend reported by Hein, Ahn, et al. (1992) for crusts from Micronesia. D15-4 and $\mathrm{D} 27-1$ show the same trends, but also have inner layers with the highest $\mathrm{Yb}$ contents. For crusts D25-3, D27-5, D32-9, D36-3, and D42-1, the innermost layers have the highest concentrations of all REEs. D-32-8 has the highest concentrations of all the REEs except $\mathrm{Ce}$ in the middle layer.

Chondrite (Anders and Grevesse, 1989)-normalized patterns show a positive $\mathrm{Ce}$ anomaly (2Ce/La+Pr from chondrite-normalized data), light REE enrichment, and a slight decrease in heavy REEs with increasing atomic number; whereas, post-Archean Australian shale (PAAS; McLennan, 1989)-normalized patterns show nearly flat heavy REEs, light REE depletion, and positive Ce anomaly (Fig. 4). Normalized REE patterns for bulk crusts and layers are shown in Figures 4-17. Patterns for individual samples (Figs. 5-17), in additional to the above characteristics, show a small positive Gd anomaly, typical of hydrogenetic Fe-Mn crusts and of seawater (Hein et al., 1988). In crusts where two layers were analyzed, the largest $\mathrm{Ce}$ anomaly occurs in the inner layer as does the highest enrichment of $\mathrm{Ce}$ relative to chondrites. When more than two layers were analyzed, the largest $\mathrm{Ce}$ anomaly was either in an interior layer or the innermost layer, whereas the greatest enrichment relative to chondrites occurred in the innermost layer.

\section{Interelement Relationships}

Correlation coefficient matrices were constructed from the chemical compositions of 46 bulk crusts (Table 12), nine thick bulk crusts ( $\geq 70 \mathrm{~mm}$; Table 13), five thin bulk crusts ( $\leq 11 \mathrm{~mm}$; Table 14), five layers from D27-5 (Table 15), and five layers from D32-9 (Table 16). In addition to 28 elements, all matrices include $\mathrm{H}_{2} \mathrm{O}^{+}, \mathrm{H}_{2} \mathrm{O}^{-}, \mathrm{CO}_{2}, \mathrm{LOI}$, and the tables for bulk crusts include longitude, latitude, water depth, and crust thickness.

For the 46 bulk crusts, statistically significant positive correlations at the $99 \%$ confidence level are found among the following selected elements, listed in order of decreasing significance for each element (Table 12): $\mathrm{Mn}$ : $\mathrm{Mo}, \mathrm{H}_{2} \mathrm{O}^{+}$, $\mathrm{LOI}, \mathrm{Ni}, \mathrm{Zn}, \mathrm{H}_{2} \mathrm{O}^{-}$, $\mathrm{Cu}, \mathrm{Co}, \mathrm{Cd}, \mathrm{V}, \mathrm{Ti}$; Fe: $\mathrm{Na}, \mathrm{As}, \mathrm{Si}, \mathrm{V}$; Si: $\mathrm{Al}, \mathrm{Na}, \mathrm{K}, \mathrm{Mg}, \mathrm{Cr}, \mathrm{As}$; P: $\mathrm{CO}_{2}, \mathrm{Ca}, \mathrm{Y}, \mathrm{Sr}$, Mo; Ba: Ce, Sr, V, Mo, Pb, Y, Zn, Ti, Ca; Pt: Rh, Ir.

All elements are associated with one or more mineral phase(s) in the crusts. We interpret these correlations and others in Table 12 to indicate the following phases and their associated elements: $\delta$ - $\mathbf{M n O}_{2}: \mathrm{Mn}, \mathrm{Ni}, \mathrm{Co}, \mathrm{Mo}, \mathrm{Cd}, \mathrm{Cu}, \mathrm{V}, \mathrm{Ti} ; \mathbf{F e}$ oxyhydroxide: $\mathrm{Fe}, \mathrm{V}, \mathrm{As}$; aluminosilicate: $\mathrm{Si}, \mathrm{Al}, \mathrm{K}, \mathrm{Na}, \mathrm{Mg}, \mathrm{Cr}, \mathrm{As}$; CFA: $\mathrm{Ca}, \mathrm{P}, \mathrm{Y}, \mathrm{CO}_{2}, \mathrm{Sr}$; residual biogenic: $\mathrm{Ba}, \mathrm{Zn}, \mathrm{V}, \mathrm{Cu}, \mathrm{Ce}, \mathrm{Sr}, \mathrm{Y}, \mathrm{Ca}$. In general, these interelement associations are similar to those determined for crusts from other areas of the central Pacific, although regional differences do occur (Hein et al., 1990, 1992b; Hein, Kang, et al., 1990).

Weak correlations exist for dredge haul locations and crust compositions. Y increases with increasing latitude (to the north) and $\mathrm{Zn}, \mathrm{Mn}, \mathrm{Fe}, \mathrm{Co}$, and $\mathrm{V}$ increase with increasing longitude (to the east), whereas $\mathrm{Co}$ and $\mathrm{Zn}$ decrease with increasing latitude. Only $\mathrm{Ti}$ increases with increasing water depth. Most PGEs (Pt, Ir, Rh), the CFA phase, and Ni increase with increasing crust thickness, whereas the iron and aluminosilicate phases decrease with increasing crust thickness.

For the nine bulk crusts thicker than $70 \mathrm{~mm}$ (Table 13), the following positive correlations between elements are found: $\mathrm{Mn}: \mathrm{Zn}, \mathrm{Na}, \mathrm{Pb}, \mathrm{As}, \mathrm{Co}, \mathrm{H}_{2} \mathrm{O}^{+}$; Fe: $\mathrm{Ba}, \mathrm{Mg}$, 
Ti, $\mathrm{Cu}, \mathrm{H}_{2} \mathrm{O}^{-}, \mathrm{Si}, \mathrm{Na}, \mathrm{K}, \mathrm{Al}, \mathrm{LOI}$; Si: K, $\mathrm{Fe}, \mathrm{H}_{2} \mathrm{O}^{-}, \mathrm{Al}, \mathrm{Ti}, \mathrm{Ba}, \mathrm{Cu}, \mathrm{Mg}, \mathrm{Ce}, \mathrm{LOI}$; P: $\mathrm{Ca}, \mathrm{CO}_{2}$, Sr, Y; Ba: Fe, Si, Na, Mg, Ti, $\mathrm{H}_{2} \mathrm{O}^{-}, \mathrm{Cu}, \mathrm{Zn}, \mathrm{Ru}$; Pt: Co, Ir. Notable differences from the entire bulk crust dataset are the correlations of $\mathrm{Pb}$ with $\mathrm{Mn}$ and $\mathrm{Cu}$ with $\mathrm{Fe}$. Fe and $\mathrm{Ti}$ are more strongly associated with the aluminosilicate phase and there has been a transfer of elements between the residual biogenic and iron oxyhydroxide phases. These differences indicate that diagenesis has affected the thicker crusts. The CFA phase and crust thickness decrease with increasing latitude. Co increases and Ce decreases with increasing longitude. With increasing water depth, $\mathrm{Al}, \mathrm{K}, \mathrm{Ti}, \mathrm{Si}, \mathrm{Cu}, \mathrm{Ce}$, and $\mathrm{Cr}$ increase and $\mathrm{Ni}, \mathrm{Co}, \mathrm{Sr}$, and $\mathrm{Cd}$ decrease.

The five thin bulk crusts ( $<11 \mathrm{~mm}$ ) have statistically significant positive correlations between the following elements (Table 14): $\mathrm{Mn}: \mathrm{H}_{2} \mathrm{O}^{-}, \mathrm{Ca}, \mathrm{Ba}, \mathrm{LOI}, \mathrm{Co}$, and at just below the 95\% confidence level, $\mathrm{Ni}$ and $\mathrm{Mo}$; Fe: P, Sr, Pb, As; Si: none; P: Fe, Sr, V, As; Ba: Mo, Mn, LOI, Y. These thin crusts have no CFA mineralization and P is correlated with $\mathrm{Fe}$, and $\mathrm{Ca}$ with the $\mathrm{Mn}$ phase. These correlations indicate that there are at least two mechanisms that incorporate P into crusts: Syndepositional adsorption and laterstage diagenesis. No elements are correlated with crust thickness, water depth, or latitude. With increasing longitude, $\mathrm{Mo}, \mathrm{Ba}, \mathrm{LOI}, \mathrm{Y}, \mathrm{V}$, and $\mathrm{CO}_{2}$ increase, whereas $\mathrm{Si}, \mathrm{Al}$, and $\mathrm{Cu}$ decrease.

For the five layers of crust D27-5 (west side of Vlinder Guyot), the following elements have statistically significant positive correlations (Table 15): $\mathbf{M n}: \mathrm{H}_{2} \mathrm{O}^{-}, \mathrm{LOI}, \mathrm{Ni}, \mathrm{Cu}, \mathrm{Rh}$, Ir; Fe: $\mathrm{H}_{2} \mathrm{O}^{+}$, As; Si: $\mathrm{H}_{2} \mathrm{O}^{+}$; P: $\mathrm{Ca}, \mathrm{Y}, \mathrm{CO}_{2}, \mathrm{Sr}, \mathrm{Ba}$; Ba: $\mathrm{Ca}, \mathrm{P}, \mathrm{Sr}, \mathrm{Ce}$; Pt: $\mathrm{Rh}$, Ir, $\mathrm{Zn}, \mathrm{Cu}$. There is a strong negative correlation between layer thickness and $\mathrm{Si}$ and $\mathrm{H}_{2} \mathrm{O}^{+}$. The hydrogenetic PGEs may be associated with the Mn phase.

The five crust layers from D32-9 (Oma Vlinder Guyot) have the following positive element correlations (Table 16): $\mathbf{M n : ~ T i ; ~ F e ~ a n d ~ S i ~ h a v e ~ n o n e ; ~ P : ~} \mathrm{Ca}, \mathrm{Ba}, \mathrm{Y}, \mathrm{Pt}, \mathrm{Rh}, \mathrm{Ir}$; Ba: Ir, Rh, Pt, Ca, P, Ce, Al; Pt: Rh, Ba, Ir, Ce, Ca, P, Al, Y. The interesting aspect of these correlations is the possible association of the PGEs with the CFA phase; or the CFA phase and some other PGE-bearing phase may simply co-vary. However, Ir and Rh have perfect correlations with $\mathrm{Ba}$.

The only association common to all of these groups is the composition of CFA, with $\mathrm{Ca}, \mathrm{P}, \mathrm{Y}, \mathrm{CO}_{2}$, and $\mathrm{Sr}$ being consistently positively correlated.

\section{Grouping of Elements: Q-Mode Factor Analysis}

Q-mode factor analysis was completed on chemical data for the 46 bulk crusts (Figs. 18, 19). Grouped elements are assigned to five factors, four of which are essentially the same as those interpreted from the correlation coefficient data. Factor analysis did not identify a group of elements that we interpret as a residual biogenic phase from correlation coefficients. Instead, factor 2 is a PGE-bearing phase that may or may not be a residual biogenic phase. Two elements that have factor scores somewhat less than the 10.21 cutoff are $\mathrm{Sr}$ and $\mathrm{Mg}$, which are commonly part of a residual biogenic (loosely bound) phase and support the interpretation of factor 2 as a residual biogenic phase. Differences are minor in elements assigned to the other four phases through interpretation of correlation coefficients and Q-mode factor assignments. Q-mode factor analysis does not include $\mathrm{V}, \mathrm{Ti}$, and $\mathrm{Cu}$ in the $\delta-\mathrm{MnO}_{2}$ phase; $\mathrm{V}$ in the $\mathrm{FeOOH}$ phase; $\mathrm{Cr}$ and $\mathrm{As}$ in the aluminosilicate phase; and $\mathrm{Sr}$ in the CFA phase. Factor analysis additionally includes $\mathrm{Ba}$ in the $\mathrm{FeOOH}$ phase; $\mathrm{Ti}$ and $\mathrm{Fe}$ in the aluminosilicate phase; and Mo in the CFA phase.

The statistical data show that the partitioning of elements in crusts is complex and that many elements occur in several crust phases. Element distributions depend on the location of Fe-Mn crust formation--that is both geographic and water depth locations. Distributions also depend on crust thickness, which reflects changes in growth rates with time and 
diagenesis within the thicker crusts. Compositions further depend on global oceanic and atmospheric changes, which manifest in temporal changes in seawater chemistry.

\section{RESOURCE CONSIDERATIONS}

The commonly cited cut off grade for potential economic development is $0.8 \%$ Co and the cut off thickness is $40 \mathrm{~mm}$. On a water-free basis, these samples are high in Pt $(0.50$ $\mathrm{ppm})$; high in $\mathrm{Mn}(22.1 \%)$; and moderate in $\mathrm{Ni}(0.40 \%)$, Co $(0.52 \%)$, and $\mathrm{Cu}(0.14 \%)$, with a mean $\mathrm{Co}+\mathrm{Ni}+\mathrm{Cu}$ content of $1.06 \%$. The mean crust thickness is $40 \mathrm{~mm}$, but the true mean crust thickness from each dredge is poorly known.

\section{REFERENCES}

Anders, E. and Grevesse, N., 1989, Abundances of the elements: Meteoritic and solar. Geochimica et Cosmochimica Acta, v. 53, p. 197-214.

Aruscavage, P.J., Kirschenbaum, H., and Brown, F., 1989, Analytical methods: The determination of 27 elements in ferromanganese materials: in Manheim, F.T. and Lane-Bostwick, C.M. (eds.), Chemical Composition of Ferromanganese Crusts in the World Ocean: A Review and Comprehensive Database. U.S. Geological Survey Open File Report 89-020, 200 p. plus 3 appendices.

Bertine, K.K., Koide, M., and Goldberg, E.D., 1993, Aspects of rhodium marine chemistry. Marine Chemistry, v. 42, p. 199-210.

Burnett, W.C., Cullen, D.J., and McMurtry, G.M., 1987, Open-ocean phosphorites--in a class by themselves? in Teleki, P.G., Dobson, M.R., Moore, J.R., and von Stackelberg, U. (eds.), Marine Minerals, D. Reidel, Dordrecht, p. 119-134.

Colodner, D.C., Boyle, E.A., and Edmond, J.M., 1991, Platinum in seawater: Abstracts and Program, 1992 Ocean Sciences Meeting, EOS, Transactions of the American Geophysical Union, v. 72, no. 51, p. 44.

Cook, H.E., Johnson, P.D., Matti, J.C., and Zemmels, I., 1975, Methods of sample preparation and X-ray diffraction data analysis (X-ray mineralogy laboratory, Deep Sea Drilling Project, University of California Riverside): in Hays, D.E., Frakes. L.A., et al., Initial Reports of the Deep Sea Drilling Project, U.S. Government Printing Office, Washington, D.C., v. 28, p. 999-1007.

Cullen, D.J. and Burnett, W.C., 1986, Phosphorite associations on seamounts in the tropical southwest Pacific Ocean. Marine Geology, v. 71, p. 215-236.

Engleman, E.E., Jackson, L.L., and Norton, D.R., 1985, Determination of carbonate carbon in geological materials by coulometric titration. Chemical Geology, v. 53, p. 125-128.

Futa, K., Peterman, Z.E., and Hein, J.R., 1988, Sr and Nd isotopic variations in ferromanganese crusts from the central Pacific: Implications for age and source provenance. Geochimica et Cosmochimica Acta, v. 52, p. 2229-2233.

Goldberg, E.D., 1987, Heavy metal analyses in the marine environment--approaches to quality control. Marine Chemistry, v. 22, p. 117-124.

Halbach, P., Manheim, F.T., and Otten, P., 1982, Co-rich ferromanganese deposits in the marginal seamount regions of the central Pacific basin--results of the Midpac ' 81 : Erzmetall, v. 35, p. 447-453.

Hein, J.R., Manheim, F.T., Schwab, W.C., and Davis, A.S., 1985a, Ferromanganese crusts from Necker Ridge, Horizon Guyot, and S.P. Lee Guyot: Geological considerations. Marine Geology, v. 69, p. 25-54.

Hein, J.R., Manheim, F.T., Schwab, W.C., Davis, A.S., Daniel, C.L., Bouse, R.M., Morgenson, L.A., Sliney, R.E., Clague, D.A., Tate, G.B., and Cacchione, D.A., $1985 \mathrm{~b}$, Geological and geochemical data for seamounts and associated ferromanganese 
crusts in and near the Hawaiian, Johnston Island, and Palmyra Island Exclusive Economic Zones. U.S. Geological Survey Open-File Report 85-292, 129 p.

Hein, J.R., Morgenson, L.A., Clague, D.A., and Koski, R.A., 1987a, Cobalt-rich ferromanganese crusts from the Exclusive Economic Zone of the United States and nodules from the oceanic Pacific: in Scholl, D.W., Grantz, A., and Vedder, J.G. (eds.), Geology and Resource Potential of the Continental Margin of Western North America and Adjacent Ocean Basins-Beaufort Sea to Baja California. Circum-Pacific Council for Energy and Mineral Resources, Earth Science Series, Houston, Texas, v. 6, p. 753-771.

Hein, J.R., Schwab, W.C., Foot, D.G., Masuda, Y., Usui, A., Davis, A.S., Fleishman, C.L., Barna, D.L., Pickthorn, L.-B., Larson, D.A., Ruzzi, P., Benninger, L.M., and Gein, L.M., 1987b, Farnella cruise F7-86-HW, cobalt-rich ferromanganese crust data report for Karin Ridge and Johnston Island, central Pacific. U.S. Geological Survey Open File Report 87-663, 34 p.

Hein, J.R., Schwab, W.C. and Davis, A.S., 1988, Cobalt and platinum-rich ferromanganese crusts and associated substrate rocks from the Marshall Islands. Marine Geology, v. 78, p. 255-283.

Hein, J.R., Kang, J.-K., Schulz, M.S., Park, B.-K., Kirschenbaum, H., Yoon, S.-H., Olson, R.L., Smith, V.K., Park., D.-W., Riddle, G.O., Quinterno, P.J., Lee, Y.-O., Davis, A.S., Kim, S.R., Pringle, M.S., Choi, D.-L., Pickthorn, L., Schlanger, S.O., Duennebier, F.K., Bergersen, D.D. and Lincoln, J.M., 1990, Geological, geochemical, geophysical, and oceanographic data and interpretations of seamounts and Co-rich ferromanganese crusts from the Marshall Islands, KORDI-USGS R.V.

Farnella Cruise F10-89-CP. U.S. Geological Survey Open File Report 90-407, 246 p.

Hein, J.R., Kirschenbaum, H., Schwab, W.C., Usui, A., Taggart, J.E., Stewart, K.C., Davis, A.S., Terashima, S., Quinterno, P.J., Olson, R.L., Pickthorn, L.G., Schulz, M.S., Morgan, C.L., 1990, Mineralogy and geochemistry of Co-rich ferromanganese crusts and substrate rocks from Karin Ridge and Johnston Island, Farnella Cruise F786-HW. U.S. Geological Survey Open File Report 90-298, 80 pp.

Hein, J.R., Ahn, J.-H., Wong, J.C., Kang, J-K., Smith, V.K., Yoon, S-H., d'Angelo, W.M., Yoo, S-O., Gibbs, A.E., Kim, H-J., Quinterno, P.J., Jung, M.-Y., Davis, A.S., Park, B.-K., Gillison, J.R., Marlow, M.S., Schulz, M.S., Siems, D.F., Taggart, J.E., Rait, N., Gray, L., Malcolm, M.J., Kavulak, M.G., Yeh, H.-W., Mann, D.M., Noble, M., Riddle, G.O., Roushey, B.H., and Smith, H., 1992, Geology, geophysics, geochemistry, and deep-sea mineral deposits, Federated States of Micronesia: KORDI-USGS R.V. Farnella cruise F11-90-CP. U.S. Geological Survey Open File Report 92-218, 191 pp.

Hein, J.R., Bohrson, W.A., Schulz, M.S., Noble, M., and Clague, D.A., 1992a, Variations in the fine-scale composition of a central Pacific ferromanganese crust: Paleoceanographic implications. Paleoceanography, v. 7, p. 63-77.

Hein, J. R., Schulz, M. S., Gein, L. M., 1992b, Central Pacific cobalt-rich ferromanganese crusts: Historical perspective and regional variability: in Keating, B. H., and Bolton, B. R., (eds.), Geology and Offshore Mineral Resources of the Central Pacific Basin. Circum-Pacific Council for Energy and Mineral Resources, Earth Sciences Series, v. 14, New York, Springer-Verlag, p. 261-283.

Hein, J.R., Yeh, H.-W., Gunn, S.H., Sliter, W.V., Benninger, L.M., and Wang, C.H., 1993, Two major Cenozoic episodes of phosphogenesis recorded in equatorial Pacific seamount deposits. Paleoceanography, v. 8, p. 293-311.

Hein, J.R., Gramm-Osipov, L., Gibbs, A.E., Kalyagin, A.N., d'Angelo, W.M., Nachaev, V.P., Briggs, P.H., Bychkov, A.S., Davis, A.S., Gusev, V.V., Chezar, H., Gorbarenko, S.A., Bullock, J.H., Kraynikov, G.A., Siems, D.F., Mikhailik, E.V., Smith, H., Eyberman, M.F., Schutt, M.J., Beloglazov, A.I., Mozherovsky, A.V., and Chichkin, R.V., 1994, Description and composition of Fe-Mn crusts, rocks, and sediments collected on Karin Ridge, R.V. Aleksandr Vinogradov cruise 91-AV- 
19/2: in Hein, J.R., Bychkov, A.S., and Gibbs, A.E. (eds.), Data and results from R.V. Aleksandr Vinogradov cruises 91-AV-19/1, north Pacific hydrochemistry transect; 91-AV-19/2, north equatorial Pacific Karin Ridge Fe-Mn crust studies; and 91-AV-19/4, northwest Pacific and Bering Sea sediment geochemistry and paleoceanographic studies. U.S. Geological Survey Open-File Report 94-230, p. 3991.

Hein, J.R., Koschinsky, A., Halbach, P., Manheim, F.T., Bau, M., Kang, J.-K., and Lubick, N., 1997, Iron and manganese oxide mineralization in the Pacific: in Nicholson, K., Hein, J.R., Bühn, B., and Dasgupta, S. (eds.) Manganese Mineralization: Geochemistry and Mineralogy of Terrestrial and Marine Deposits. Geological Society Special Publication No. 119, London, p. 123-138.

Hodge, V., Stallar, M., Koide, M., and Goldberg, E.D., 1986, Determination of platinum and iridium in marine waters, sediments, and organisms. Analytical Chemistry, v. 58, p. 616-620.

Ingram, B.L., Hein, J.R., and Farmer, G.L., 1990, Age determinations and growth rates of Pacific ferromanganese deposits using strontium isotopes. Geochimica et Cosmochimica Acta, v. 54, p. 1709-1721.

Jackson, L.L., Brown, F.W., and Neil, S.T., 1987, Major and minor elements requiring individual determination, classical whole rock analysis, and rapid rock analysis: in Baedecker, P.A. (ed.) Methods for Geochemical Analysis. U.S. Geological Survey Bulletin 1770, p. G1-G23.

Kastner, M., 1979, Zeolites: in Burns, R.G. (ed.), Marine Minerals, Mineralogical Society of America Short Course Notes, v. 6, p. 111-122.

Klovan, J.E. and Imbrie, J., 1971, An algorithm and FORTRAN-IV program for largescale Q-mode factor analysis and calculation of factor scores. Mathematical Geology, v. 3 , p. $61-77.1$

Koppers, A., 1997, The geochronology of western seamounts and implications for plate motion. Ph.D. thesis, Fee University of Amsterdam, December, 1997.

Koschinsky, A. and Halbach, P., 1995, Sequential leaching of marine ferromanganese precipitates: Genetic implications. Geochimica et Cosmochimica Acta, v. 59, p. 51135132.

Lichte, F.E., Golightly, D.W., and Lamothe, P.J., 1987a, Inductively coupled plasmaatomic emission spectrometry: in Baedecker, P.A. (ed.), Methods for Geochemical Analysis. U.S. Geological Survey Bulletin 1770, p. B1-B10.

Lichte, F.E., Meier, A.L., and Crock, J.G., 1987b, Determination of the rare earth elements in geological materials by inductively coupled plasma-mass spectrometry. Analytical Chemistry, v. 59, p. 1150-1157.

Ling, H.F., Burton, K.W., O'Nions, R.K., Kamber, B.S., von Blanckenburg, F., Gibbs, A.J., and Hein, J.R., 1997, Evolution of $\mathrm{Nd}$ and $\mathrm{Pb}$ isotopes in central Pacific seawater from ferromanganese crusts. Earth and Planetary Science Letters, v. 146, p. $1-12$.

Manheim, F.T. and Gulbrandsen, R.A., 1979, Marine phosphorites. in Burns, R.G. (ed.), Marine Minerals. Mineralogical Society of America Short Course Notes, v. 6, p. 151-173.

McLennan, S.M., 1989, Rare earth elements in sedimentary rocks: Influence of provenance and sedimentary processes: in Lipin, B.R. and McKay, G.A. (eds.) Geochemistry and Mineralogy of Rare Earth Elements. Mineralogical Society of America's Reviews in Mineralogy, v. 21, Washington D.C.

Parthé, E. and Crocket, J.H., 1978, Platinum group: in Wedepohl, K.H. (ed.) Handbook of Geochemistry, v. II/5, Springer-Verlag, Berlin, p. 78-A1-78-O7.

Peck, L.C., 1964, Systematic analysis of silicates. U.S. Geological Survey Bulletin 1170, $89 \mathrm{p}$.

Pichochi, C. and Hoffert, M., 1987, Characteristics of Co-rich ferromanganese nodules and crusts sampled in French Polynesia. Marine Geology, v. 77, p. 109-119. 
Puteanus, D. and Halbach, P., 1988, Correlation of Co concentration and growth rate: A method for age determination of ferromanganese crusts. Chemical Geology, v. 69, p. 73-85.

Shapiro, L., 1975, Rapid analysis of silicate, carbonate, and phosphate rocks--revised edition. U.S. Geological Survey Bulletin 1401, 76 p.

Taggart, J.E., Lindsay, J.R., Scott, B.A., Vivit, D.V., Bartel, A.J., and Stewart, K.C., 1987, Analysis of geologic materials by wavelength-dispersive X-ray fluorescence spectrometry: in Baedecker, P.A. (ed.), Methods for Geochemical Analysis. U.S. Geological Survey Bulletin 1770, p. E1-E19. 


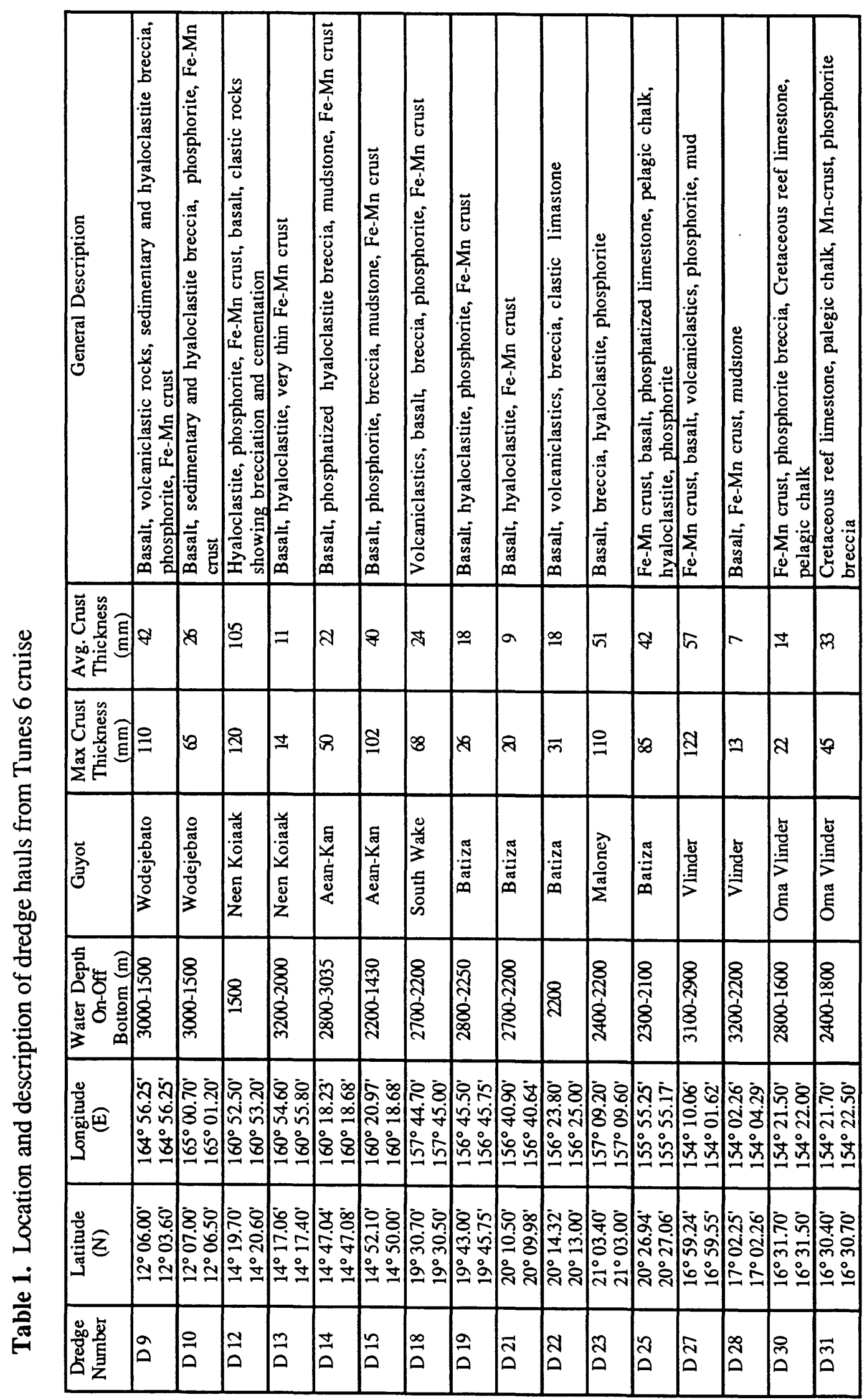




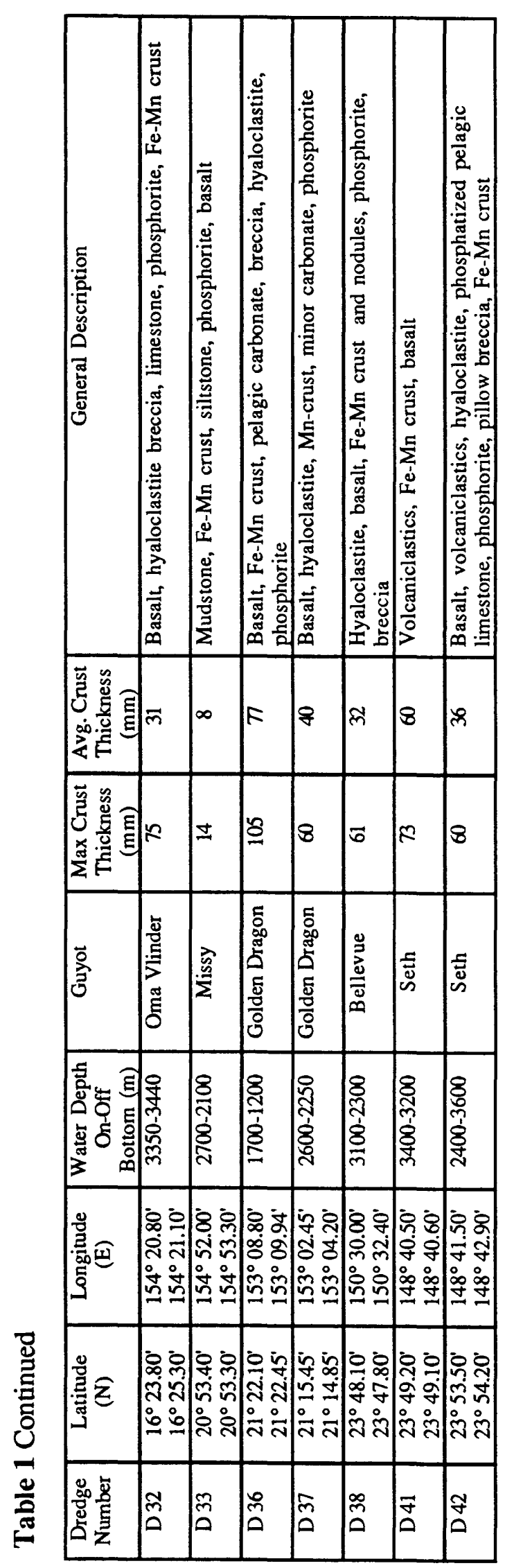


Table 2. X-ray diffraction mineralogy of substrate rocks from Tunes 6 cruise

\begin{tabular}{|c|c|c|c|c|}
\hline Sample & Major 1 & Moderate & Minor/Trace & Rock/Sediment \\
\hline D9-22B & $\mathrm{CFA}^{2}$ & Calcite & Chlorite & Phosphorite (clastic limestone) ${ }^{3}$ \\
\hline D9-24 & CFA & Phillipsite, plagioclase & Smectite & CFA-cemented breccia 4 \\
\hline$\overline{D 10-1 B}$ & CFA & Phillipsite & Smectite & $\begin{array}{l}\text { CFA-cemented breccia in contact } \\
\text { w/ phosphorite (foraminifera sand) }\end{array}$ \\
\hline $\mathrm{D} 10-3$ & CFA & Plagioclase & Smectite & CFA-cemented breccia \\
\hline D10-5A & CFA & - & Smectite & Phosphorite (breccia) \\
\hline D12-3B & CFA & Plagioclase & Smectite, quartz & Phosphorite (sandstone) \\
\hline D13-13B & $\begin{array}{l}\text { Plagioclase } \\
\text { pyroxene }\end{array}$ & Magnetite & Smectite & Basalt \\
\hline D14-17B & $\begin{array}{l}\text { K-feldspar } \\
\text { magnetite }\end{array}$ & Hematite, smectite & - & Mudstone \\
\hline D14-18 & $\begin{array}{l}\text { Amorphous } \\
\text { smectite, CFA }\end{array}$ & - & - & Mudstone \\
\hline $\mathrm{D} 15-3$ & K-feldspar, CFA & Smectite & - & Mudstone \\
\hline $\mathrm{D} 15-4 \mathrm{E}$ & CFA & Barite & - & Phosphorite (micritic limestone) \\
\hline$\overline{\mathrm{D} 18-3}$ & Phillipsite & Magnetite & $\begin{array}{l}\begin{array}{l}\text { Smectite } \\
\text { plagioclase }\end{array} \\
\end{array}$ & Breccia \\
\hline D18-5B & CFA & - & - & Phosphorite (foraminifera sand) \\
\hline D21-2 & Goethite & Calcite, hematite & - & $\begin{array}{l}\text { Yellow-red mineral replacement of } \\
\text { basalt }\end{array}$ \\
\hline D21-3B & Smectite & - & - & Yellow replacement mineral \\
\hline D22-1B & $\begin{array}{l}\text { Plagioclase } \\
\text { smectite }\end{array}$ & CFA, hematite & - & Amygdaloid basalt \\
\hline D23-1E & $\begin{array}{l}\text { Phillipsite, CFA } \\
\text { plagioclase }\end{array}$ & - & Smectite & CFA-cemented breccia \\
\hline D23-5B & CFA, goethite & Plagioclase, pyroxene & Smectite & CFA-cemented breccia \\
\hline $\bar{D} 25-2 \mathrm{~B}$ & CFA & Plagioclase & Smectite, quartz & $\begin{array}{l}\text { Phosphorite (volcaniclastic } \\
\text { calcareous sandstone) }\end{array}$ \\
\hline D25-3E & CFA & Plagioclase & Smectite & Phosphorite (hyaloclastite) \\
\hline D25-3F & CFA & - & - & Phosphorite \\
\hline D28-1B & K-feldspar & $\begin{array}{l}\text { Pyroxene, CFA } \\
\text { phillipsite, plagioclase }\end{array}$ & Smectite & Mudstone \\
\hline D31-1B & CFA & - & Smectite, quartz & Phosphorite (limestone) \\
\hline $\bar{D} 32-6 \mathrm{~A}$ & CFA & Phillipsite, K-feldspar & $\begin{array}{l}\text { Smectite } \\
\text { clinoptilolite }\end{array}$ & Phosphorite (limestone) \\
\hline D32-8A & CFA & Smectite & - & Phosphorite \\
\hline D32-9A & CFA & - & K-feldspar & White phosphorite \\
\hline D32-9B & CFA & Barite & - & Brown fracture fill \\
\hline D33-1B & $\begin{array}{l}\begin{array}{l}\text { Clinoptilolite } \\
\text { smectite }\end{array} \\
\end{array}$ & Magnetite, hematite & Plagioclase & Pale brown mudstone \\
\hline D33-1C & Smectite & Hematite, phillipsite & Clinoptilolite & Dark brown mudstone \\
\hline D33-1D & Smectite & - & - & Green mudstone \\
\hline D33-2B & CFA & Phillipsite & - & Phosphorite (limestone) \\
\hline D33-3 & Smectite & - & - & Mudstone/tuff \\
\hline D37-1 & CFA & - & - & Phosphorite \\
\hline D38-2-1 & CFA & Phillipsite, smectite & - & Phosphorite (basalt) \\
\hline D42-1D & Phillipsite & - & - & Botryoidal crystals in vug \\
\hline
\end{tabular}

1Major: $\geq 25 \%$, Moderate: $\geq 5 \%$ to $<25 \%$, Minor: $<5 \%$

2CFA is carbonate fluorapatite

${ }^{3}$ Rock types in parentheses are replaced by phosphorite

${ }^{4}$ All breccias are sedimentary, and most are volcaniclastic 


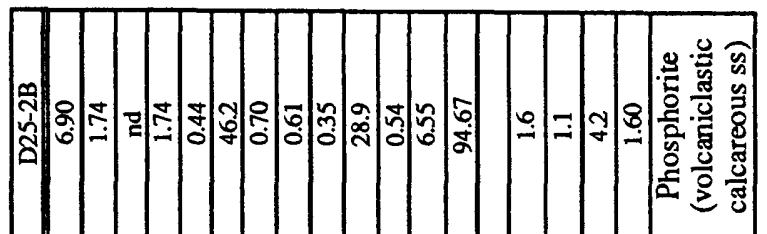

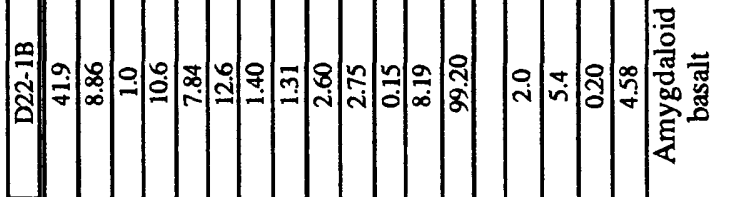

年

题

它



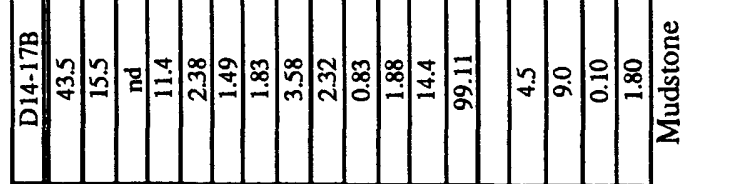

m.

mे

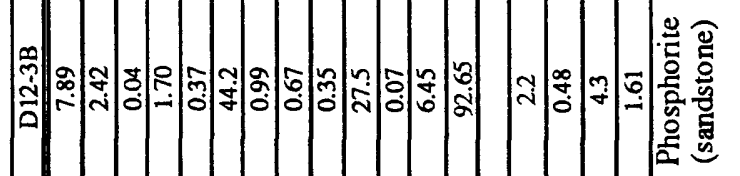

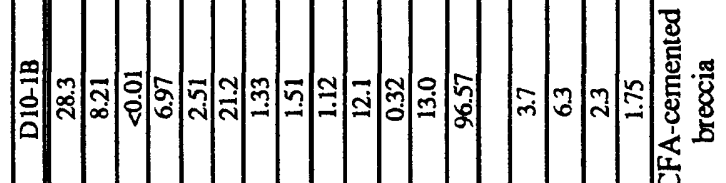

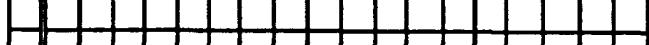

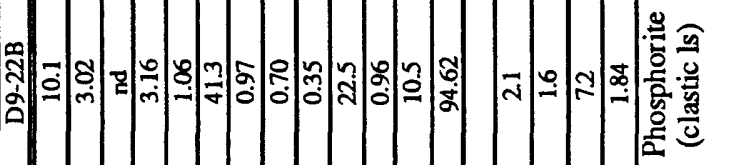

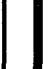

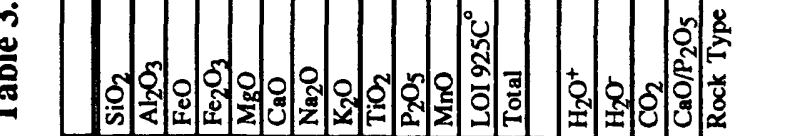

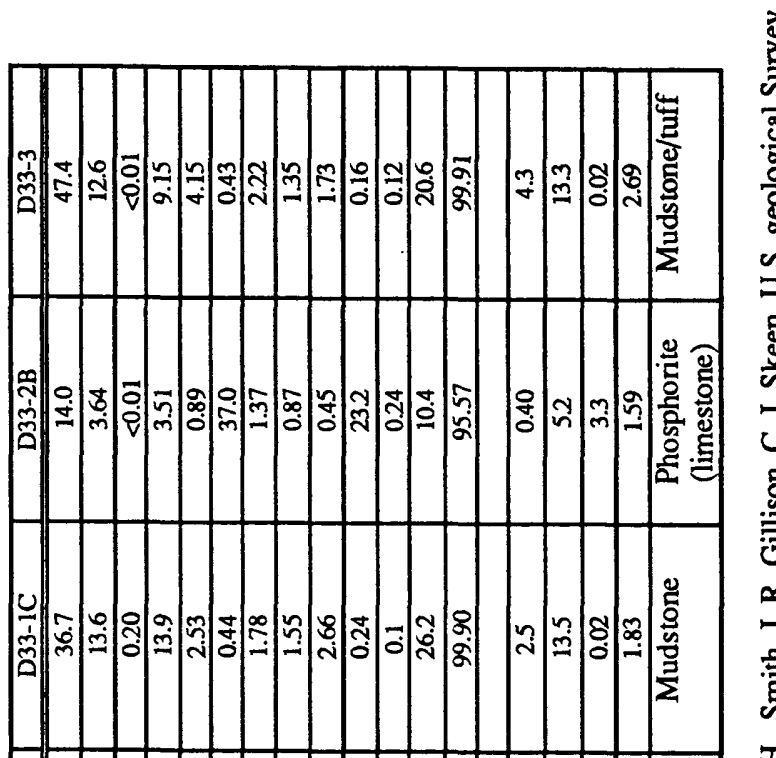

लिं

ली่

$\ddot{3}$

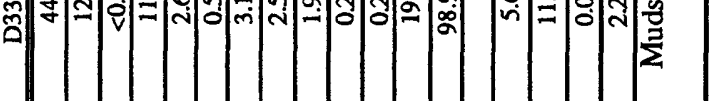

商

总忽

商

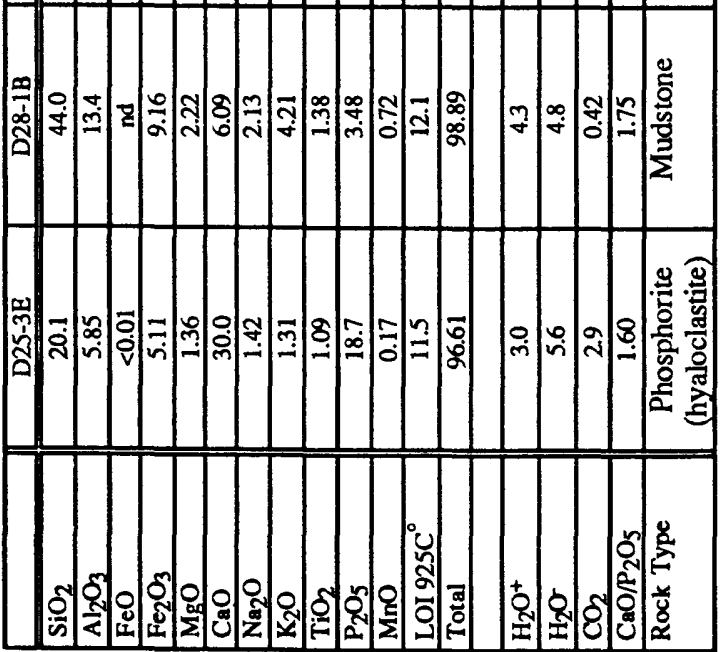

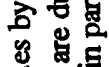

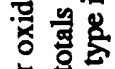

호월 
Table 4. Calculated growth rates of Fe-Mn crusts from Tunes 6 cruise

\begin{tabular}{|c|c|c|c|c|c|c|}
\hline Sample & $\begin{array}{c}\text { Type \& } \\
\text { Interval } \\
(\mathrm{mm}) \mathbf{1} \\
\end{array}$ & $\underset{(w t . \%)}{\text { Mn }}$ & $\begin{array}{c}P \\
\text { (wt.\%) }\end{array}$ & $\begin{array}{c}\mathrm{Co} \\
(\mathrm{ppm})\end{array}$ & $\begin{array}{c}\text { Growth Rate } \\
(\mathrm{mm} / \mathrm{Ma})^{2}\end{array}$ & $\begin{array}{c}\text { Crust } \\
\text { Age } \\
\text { (Ma) } \\
\end{array}$ \\
\hline D9-11 & Bulk $(0-30)$ & 26.0 & 0.33 & 8493 & 2.1 & 14.3 \\
\hline D9-22A & Bulk $(0-41)$ & 21.3 & 0.45 & 3856 & 8.8 & 4.7 \\
\hline D9-25A & Layer $(0-23)$ & 24.1 & 0.35 & 6818 & 2.9 & 7.9 \\
\hline D9-25B & Layer (23-43) & 19.6 & 0.35 & 4183 & 7.2 & 10.7 \\
\hline D10-1A & Bulk $(0-49)$ & 27.1 & 0.32 & 5683 & 3.9 & 12.6 \\
\hline D12-3A & Bulk $(0-45)$ & 24.3 & 0.39 & 5676 & 3.9 & 11.5 \\
\hline D13-13A & Bulk $(0-14)$ & 23.1 & 0.39 & 6114 & 3.5 & 4.1 \\
\hline D14-11 & Bulk $(0-30)$ & 22.8 & 0.32 & 6166 & 3.4 & 8.8 \\
\hline D14-17A & Bulk (0-15) & 19.6 & 0.31 & 4830 & 5.3 & 2.9 \\
\hline D14-19A & Bulk (0-29) & 24.0 & 0.35 & 5851 & 3.7 & 7.8 \\
\hline D15-1A & Bulk (0-29) & 20.6 & 2.19 & 3732 & $-n^{3}$ & - \\
\hline D15-1B & Bulk $(0-20)$ & 15.3 & 5.52 & 2233 & - & - \\
\hline D15-4A & Bulk (0-93) & 20.9 & 2.87 & 4961 & 2.5 & 36.8 \\
\hline D15-4B & Layer $(0-33)$ & 25.0 & 0.36 & 7371 & 2.6 & 12.8 \\
\hline D15-4C & Layer (30-62) & 27.6 & 0.36 & 7034 & 2.8 & 23.3 \\
\hline D15-4D & Layer (62-95) & 16.1 & 6.09 & 2609 & 2.3 & 37.5 \\
\hline D18-1A & Bulk (0-68) & 29.0 & 0.40 & 6777 & 2.9 & 23.3 \\
\hline D18-1B & Layer $(0-18)$ & 24.1 & 0.40 & 5764 & 3.8 & 4.7 \\
\hline D18-1C & Layer (18-56) & 30.9 & 0.32 & 8298 & 2.2 & 22.2 \\
\hline D18-5A & Bulk (0-8) & 21.5 & 0.44 & 5645 & 3.9 & 2.0 \\
\hline D19-1 & Bulk (0-26) & 19.9 & 0.37 & 5033 & 4.9 & 5.4 \\
\hline D19-2 & Bulk $(0-20)$ & 24.2 & 0.35 & 6174 & 3.4 & 5.9 \\
\hline $\mathrm{D} 21-3 \mathrm{~A}$ & Bulk (0-15) & 18.1 & 0.36 & 4774 & 5.4 & 2.8 \\
\hline $\mathrm{D} 21-4$ & Bulk (0-15) & 20.0 & 0.36 & 4927 & 5.1 & 3.0 \\
\hline$\overline{\mathrm{D} 22-1 \mathrm{~A}}$ & Bulk (0-30) & 20.1 & 0.40 & 4947 & 5.0 & 6.0 \\
\hline $\bar{D} 22-2$ & Bulk (0-22) & 18.7 & 0.47 & 5355 & 4.3 & 5.1 \\
\hline D23-1A & Bulk $(0-70)$ & 23.0 & 0.39 & 5142 & 4.7 & 15.0 \\
\hline $\mathrm{D} 23-1 \mathrm{~B}, \mathrm{C}$ & Layer $(0-25)$ & 21.3 & 0.36 & 4267 & 6.9 & 3.7 \\
\hline D23-1D & Layer $(25-70)$ & 27.6 & 0.40 & 6069 & 3.5 & 16.6 \\
\hline D23-5A & Bulk $(0-40)$ & 25.1 & 1.85 & 3038 & - & - \\
\hline $\mathrm{D} 25-1$ & Bulk (0-55) & 23.0 & 0.36 & 4865 & 5.2 & 10.6 \\
\hline $\mathrm{D} 25-2 \mathrm{~A}$ & Bulk (0-19) & 18.2 & 0.35 & 4681 & 5.6 & 3.4 \\
\hline D25-3A & Bulk $(0-83)$ & 24.5 & 0.41 & 5306 & 4.4 & 18.8 \\
\hline D25-3B & Layer (0-24) & 22.6 & 0.37 & 4781 & 5.4 & 4.5 \\
\hline $\mathrm{D} 25-3 \mathrm{C}$ & Layer (24-46) & 28.8 & 0.37 & 6319 & 3.3 & 11.2 \\
\hline $\bar{D} 25-3 \mathrm{D}$ & Layer $(46-80)$ & 23.4 & 0.59 & 4121 & 7.4 & 15.8 \\
\hline D27-1A & Bulk (0-62) & 22.6 & 1.46 & 3595 & 6.1 & 10.2 \\
\hline D27-1B & Layer $(0-14)$ & 22.7 & 0.39 & 4412 & 6.4 & 2.2 \\
\hline D27-1C & Layer (14-51) & 20.8 & 2.60 & 3121 & 6.0 & 8.4 \\
\hline D27-4 & Bulk $(0-18)$ & 19.7 & 0.38 & 5125 & 4.7 & 3.8 \\
\hline D27-5A & Bulk (0-114) & 21.9 & 1.37 & 3962 & 4.7 & 24.5 \\
\hline D27-5B & Layer $(0-11)$ & 18.2 & 0.43 & 4935 & 5.1 & 2.2 \\
\hline D27-5C & Layer (11-23) & 19.7 & 0.37 & 5125 & 4.7 & 6.9 \\
\hline D27-5D & Layer (23-53) & 25.4 & 0.41 & 5501 & 4.1 & 14.1 \\
\hline D27-5E & Layer $(53-84)$ & 21.4 & 1.47 & 3217 & 5.1 & 20.2 \\
\hline D27-5F & Layer (83-114) & 16.4 & 4.28 & 2138 & 7.4 & 24.4 \\
\hline D28-1A & Bulk $(0-11)$ & 18.2 & 0.32 & 4799 & 5.3 & 2.1 \\
\hline
\end{tabular}


Table 4 Continued

\begin{tabular}{|c|c|c|c|c|c|c|}
\hline D30-1A & Bulk (0-21) & 19.8 & 0.34 & 5013 & 4.9 & 4.3 \\
\hline D31-1A & Bulk (0-45) & 21.4 & 0.31 & 6434 & 3.2 & 14.2 \\
\hline D32-2 & Bulk (0-22) & 21.7 & 0.31 & 6522 & 3.1 & 7.1 \\
\hline D32-5 & Bulk (0-72) & 26.0 & 0.41 & 5328 & 4.4 & 16.5 \\
\hline D32-6B & Bulk (0-3) & 18.1 & 0.39 & 3876 & 8.7 & 0.4 \\
\hline D32-8B & Bulk $(0-40)$ & 22.6 & 0.39 & 5459 & 4.2 & 9.6 \\
\hline D32-8C & Layer (0-5) & 16.5 & 0.41 & 3295 & 14.3 & 0.4 \\
\hline D32-8D & Layer $(5-20)$ & 21.2 & 0.38 & 5305 & 4.4 & 3.8 \\
\hline D32-8E & Layer $(20-40)$ & 25.5 & 0.35 & 6711 & 3.0 & 10.5 \\
\hline D32-9C & Bulk $(0-60)$ & 23.3 & 0.41 & 6036 & 3.5 & 17.0 \\
\hline D32-9D & Layer (0-2) & 21.2 & 0.45 & 3968 & 8.2 & 0.3 \\
\hline D32-9E & Layer (2-17) & 24.1 & 0.41 & 5221 & 4.5 & 3.6 \\
\hline D32-9F & Layer (17-30) & 28.7 & 0.36 & 6019 & 3.5 & 7.2 \\
\hline D32-9G & Layer $(30-50)$ & 26.3 & 0.39 & 6510 & 3.1 & 13.7 \\
\hline D32-9H & Layer $(50-60)$ & 25.1 & 0.75 & 4045 & 7.8 & 15.0 \\
\hline D33-1A & Bulk $(0-10)$ & 18.4 & 0.37 & 4331 & 6.6 & 1.5 \\
\hline D33-2A & Bulk $(0-10)$ & 16.6 & 0.41 & 3713 & 9.8 & 1.0 \\
\hline D36-1 & Bulk (0-72) & 27.5 & 1.10 & 5777 & - & - \\
\hline D36-3A & Bulk (0-78) & 22.4 & 1.98 & 5013 & 3.8 & 20.6 \\
\hline D36-3B & Layer $(0-18)$ & 21.1 & 0.51 & 5277 & 4.5 & 4.1 \\
\hline D36-3C & Layer (18-49) & 24.5 & 0.44 & 5722 & 3.9 & 12.1 \\
\hline D36-3D & Layer (49-81) & 22.1 & 3.65 & 4297 & 3.4 & 21.5 \\
\hline D36-4 & Bulk $(0-76)$ & 26.1 & 1.37 & 5761 & - & - \\
\hline D37-2 & Bulk (0-50) & 21.6 & 0.53 & 5405 & 4.3 & 11.7 \\
\hline D37-4A & Bulk (0-50) & 22.6 & 0.49 & 4515 & 6.1 & 8.3 \\
\hline D37-4B & Layer $(0-30)$ & 21.1 & 0.40 & 3826 & 9.0 & 3.3 \\
\hline D37-4C & Layer $(30-50)$ & 22.9 & 1.01 & 4980 & 5.0 & 7.4 \\
\hline D38-1A & Bulk $(0-55)$ & 22.6 & 0.53 & 4927 & 5.1 & 10.9 \\
\hline D38-1B & Layer $(0-28)$ & 23.3 & 0.38 & 5062 & 4.8 & 5.8 \\
\hline D38-1C & Layer (28-57) & 21.8 & 0.41 & 3951 & 8.3 & 8.3 \\
\hline D38-2-2A & Bulk $(0-13)$ & 22.3 & 0.43 & 4849 & 5.2 & 2.5 \\
\hline D41-1A & Bulk (0-72) & 21.6 & 0.46 & 4723 & 5.5 & 13.1 \\
\hline D41-1B & Layer $(0-32)$ & 21.5 & 0.39 & 4570 & 5.9 & 5.4 \\
\hline D41-1C & Layer (32-73) & 23.0 & 0.53 & 4775 & 5.4 & 13.0 \\
\hline D42-1A & Bulk $(0-20)$ & 19.9 & 0.44 & 4122 & 7.4 & 2.7 \\
\hline D42-1B & Layer (0-7) & 18.6 & 0.44 & 3851 & 8.8 & 0.8 \\
\hline D42-1C & Layer (7-20) & 21.3 & 0.41 & 4933 & 5.1 & 3.4 \\
\hline
\end{tabular}

1 Intervals measured from the outer surface of crusts

${ }^{2}$ Growth rates determined via the equations of Puteanus and Halbach (1988); crust age was calculated from growth rate and crust thickness; the age of a layer is for the base of that layer

${ }^{3}$ Growth rates and crust ages could not be determined because samples were heavily phosphatized and no unphosphatized younger layers existed for comparison 
Table 5. X-ray diffraction mineralogy of Fe-Mn crusts from Tunes 6 cruise

\begin{tabular}{|c|c|c|c|}
\hline Sample & $\begin{array}{c}\text { Type } \underset{(\mathrm{mm})}{\&} \text { Interval } \\
\end{array}$ & $\begin{array}{c}\delta-\mathrm{MnO}_{2} \\
(\%)^{2}\end{array}$ & $\begin{array}{c}\text { Others } \\
(\%)\end{array}$ \\
\hline D9-11 & Bulk (0-30) & 98 & 1-goethite, <1-K-feldspar \\
\hline D9-22A & Bulk $(0-41)$ & 91 & 8-phillipsite, <1-amphibole, <1-goethite \\
\hline D9-25A & Layer $(0-23)$ & 100 & trace-quartz \\
\hline D9-25B & Layer (23-43) & 98 & 1-goethite, <1-smectite, <1-quartz \\
\hline D10-1A & Bulk $(0-49)$ & 93 & 6-goethite, <1-smectite(?) \\
\hline D13-13A & Bulk (0-14) & 97 & 2-quartz, 1-plagioclase \\
\hline D14-11 & Bulk (0-30) & 98 & 1-plagioclase, 1-quartz \\
\hline D14-17A & Bulk (0-15) & 93 & 3-plagioclase, 2-quartz, 2-hematite \\
\hline D14-19A & Bulk (0-29) & 97 & 2-palygorskite, 1-plagioclase, <l-quartz \\
\hline D15-1A & Bulk (0-29) & 90 & 8-CFA, 1-plagioclase, 1-quartz \\
\hline D15-1B & Layer $(0-20)$ & 81 & 16-CFA, 1-plagioclase, 1-quartz, 1-todorokite (?) \\
\hline $\mathrm{D} 15-4 \mathrm{~A}$ & Bulk (0-93) & 93 & 6-CFA, <1-quartz, <1-plagioclase \\
\hline D15-4B & Layer $(0-33)$ & 96 & 3-quartz, 1-plagioclase \\
\hline $\mathrm{D} 15-4 \mathrm{C}$ & Layer $(30-62)$ & 99 & $<1$-plagioclase, $<1$-quartz \\
\hline D15-4D & Layer (62-95) & 90 & 9-CFA, <1-geothite, <1-plagioclase, <1-quartz \\
\hline D18-1A & Bulk $(0-68)$ & 98 & 1-plagioclase, 1-quartz \\
\hline D18-1B & Layer $(0-18)$ & 96 & 2-CFA, 1-plagioclase, 1-quartz \\
\hline D18-1C & Layer (18-56) & 100 & trace-quartz \\
\hline D18-5A & Bulk $(0-8)$ & 97 & 2-quartz, 1-plagioclase \\
\hline D19-1 & Bulk (0-26) & 94 & 5-quartz, 1-plagioclase \\
\hline D19-2 & Bulk (0-20) & 98 & 1-quartz, <1-plagioclase, $<1$-smectite \\
\hline $\mathrm{D} 21-3 \mathrm{~A}$ & Bulk (0-15) & 93 & 3-quartz, 2-plagioclase, 2-smectite (?) \\
\hline D21-4 & Bulk (0-15) & 97 & 2-quartz, 1-plagioclase \\
\hline D22-1A & Bulk $(0-30)$ & 95 & 3-quartz, 2-plagioclase \\
\hline D22-2 & Bulk (0-22) & 91 & $\begin{array}{l}\text { 5-plagioclase, 2-birnessite, 1-quartz, <1-calcite, } \\
<1 \text { - smectite }\end{array}$ \\
\hline D23-1A & Bulk $(0-70)$ & 97 & 2-plagioclase, 1-quartz \\
\hline D23-1B,C & Layer $(0-25)$ & 97 & 1-phillipsite, 1-plagioclase, 1-quartz \\
\hline D23-1D & Layer $(25-70)$ & 98 & 1-plagioclase, 1-quartz \\
\hline D23-5A & Bulk $(0-40)$ & 94 & 5-CFA, <1-plagioclase, 1-quartz \\
\hline D25-1 & Bulk (0-55) & 98 & 1-plagioclase, <1-quartz, <1-smectite \\
\hline D25-2A & Bulk (0-19) & 90 & 5-phillipsite, 3-plagioclase, 2-quartz \\
\hline D25-3A & Bulk (0-83) & 97 & 1-CFA, 1-plagioclase, 1-quartz \\
\hline $\mathrm{D} 25-3 \mathrm{~B}$ & Layer $(0-24)$ & 98 & 1-quartz, <1-plagioclase \\
\hline D25-3C & Layer (24-46) & 98 & 1-plagioclase, 1-quartz \\
\hline $\mathrm{D} 25-3 \mathrm{D}$ & Layer $(46-80)$ & 96 & 2-phillipsite, 1-plagioclase, 1-quartz \\
\hline $\mathrm{D} 27-1 \mathrm{~A}$ & Bulk $(0-62)$ & 94 & 6-CFA, <1-quartz \\
\hline D27-1B & Layer $(0-14)$ & 99 & 1-quartz \\
\hline D27-1C & Layer (14-51) & 93 & 6-CFA, 1-quartz \\
\hline D27-4 & Bulk $(0-18)$ & 98 & 1-plagioclase, <1-quartz \\
\hline D27-5A & Bulk (0-114) & 95 & 4-CFA, <1-quartz \\
\hline $\mathrm{D} 27-5 \mathrm{~B}$ & Layer $(0-11)$ & 97 & 2-quartz, 1-plagioclase \\
\hline $\mathrm{D} 27-5 \mathrm{C}$ & Layer (11-23) & 99 & $<1$-quartz \\
\hline D27-5D & Layer (23-53) & 99 & 1-quartz \\
\hline D27-5E & Layer $(53-83)$ & 96 & 3-CFA, 1-quartz \\
\hline D27-5F & Layer (83-114) & 81 & 19-CFA \\
\hline D28-1A & Bulk (0-11) & 93 & 5-phillipsite, 1-plagioclase 1-quartz \\
\hline D31-1A & Bulk (0-45) & 96 & 2-quartz, 1-plagioclase, 1-smectite \\
\hline D32-2 & Bulk (0-22) & 98 & 1-chlorite (?), 1-quartz \\
\hline D32-5 & Bulk (0.72) & 97 & 2-quartz, 1-plagioclase \\
\hline D32-6B & Bulk (0-3) & 93 & 4-quartz, 2-plagioclase, 1-smectite \\
\hline D32-8B & Bulk $(0-40)$ & 97 & 2-quartz, 1-plagioclase \\
\hline D32-8C & Layer $(0-5)$ & 92 & 5-quartz, 3-plagioclase \\
\hline
\end{tabular}


Table 5 Continued

\begin{tabular}{|c|c|c|c|}
\hline D32-8D & Layer $(5-20)$ & 96 & 2-quartz, 1-plagioclase, 1-stevensite (?) \\
\hline D32-8E & Layer $(20-40)$ & 99 & 1-quartz \\
\hline D32-9C & Bulk $(0-60)$ & 99 & $<1$-plagioclase, $<1$-quartz \\
\hline D32-9D & Layer $(0-2)$ & 97 & 2-quartz, 1-plagioclase \\
\hline D32-9E & Layer $(2-17)$ & 99 & 1-quartz \\
\hline D32-9F & Layer (17-30) & 99 & $<1$-clinoptilolite, $<1$-stevensite \\
\hline $\mathrm{D} 32-9 \mathrm{G}$ & Layer (30-50) & 99 & 1-quartz \\
\hline D32-9H & Layer $(50-60)$ & 98 & 1-CFA, 1-quartz \\
\hline D33-1A & Bulk (0-10) & 93 & 4-quartz, 2-plagioclase, <1-calcite (?), <1-smectite \\
\hline D33-2A & Bulk (0-10) & 92 & 5-quartz, 2-plagioclase \\
\hline D36-1 & Bulk (0-72) & 97 & 2-CFA, <1-plagioclase, <1-quartz \\
\hline D36-3A & Bulk (0-78) & 95 & 4-CFA, 1-quartz \\
\hline D36-3B & Layer $(0-18)$ & 95 & 3-quartz, 2-plagioclase \\
\hline D36-3C & Layer (18-49) & 99 & 1-quartz \\
\hline D36-3D & Layer (49-81) & 83 & 16-CFA, 1-quartz \\
\hline D36-4 & Bulk (0-76) & 96 & 2-CFA, 1-quartz, 1-plagioclase \\
\hline D37-2 & Bulk (0-50) & 94 & 5-phillipsite, $<1$-plagioclase, <1-quartz \\
\hline D37-4A & Bulk (0-50) & 97 & 2-quartz, 1-plagioclase \\
\hline D37-4C & Layer $(30-50)$ & 93 & 4-phillipsite, 2-CFA, <1-plagioclase, <1-quartz \\
\hline$\overline{\mathrm{D} 38-1 \mathrm{~A}}$ & Bulk (0-55) & 99 & 1-quartz \\
\hline D38-1B & Layer $(0-28)$ & 97 & 2-quartz, <1-plagioclase, $<1$-smectite \\
\hline D38-1C & Layer (28-57) & 94 & 2-plagioclase, 2-quartz, 1-CFA, 1-smectite \\
\hline D38-2-2A & Bulk (0-13) & 95 & 2-plagioclase, 1-CFA, 1-quartz \\
\hline D41-1A & Bulk (0-72) & 97 & 2-plagioclase, 1-quartz \\
\hline D41-1B & Layer $(0-32)$ & 99 & 1 -quartz, <1-plagioclase \\
\hline D41-1C & Layer (32-73) & 97 & 1-hematite, 1-plagioclase, 1-quartz \\
\hline D42-1A & Bulk $(0-20)$ & 98 & 2-quartz \\
\hline D42-1B & Layer $(0-7)$ & 92 & 4-plagioclase, 2-pyroxene (?), 2-quartz \\
\hline D42-1C & Layer $(7-20)$ & 97 & 1-phillipsite, 1-quartz \\
\hline
\end{tabular}

1Intervals measured from the outer surface of crusts

2Percentages were determined by using the following weighting factors relative to quartz set at $1: \delta-\mathrm{MnO}_{2}$ 70; todorokite 10; birnessite 12 (Hein et al., 1988); carbonate fluorapatite (CFA) 3.1; plagioclase 2.8; calcite 1.65; smectite 3.0; goethite 7.0; phillipsite 17.0; illite 6.0; pyroxene 5.0; halite 2.0 (Cook et al., 1975); the limit of detection for each mineral falls between 0.2 and $1.0 \%$, except the manganese minerals which are greater, perhaps as much as $10 \%$ for $\delta-\mathrm{MnO}_{2}$ 


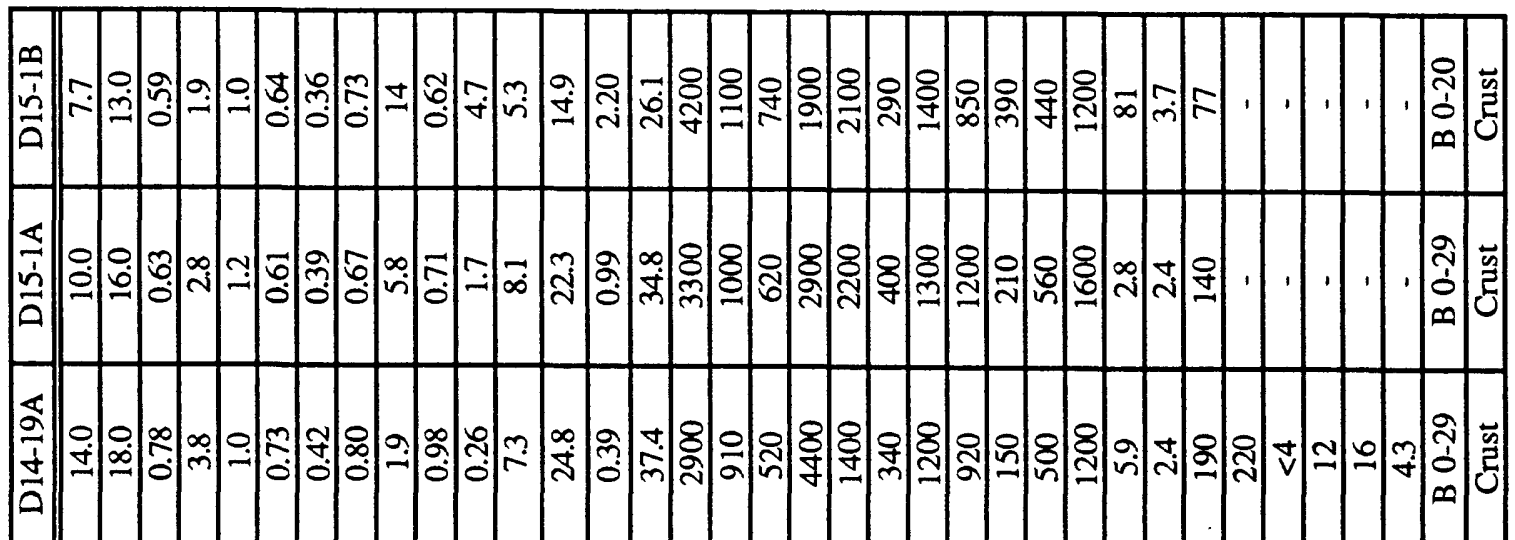

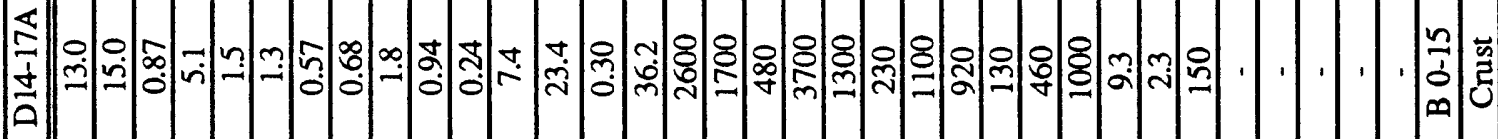

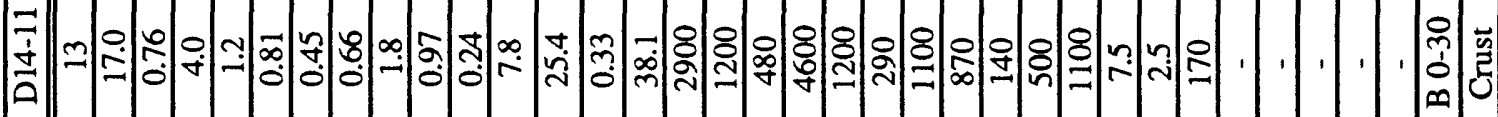

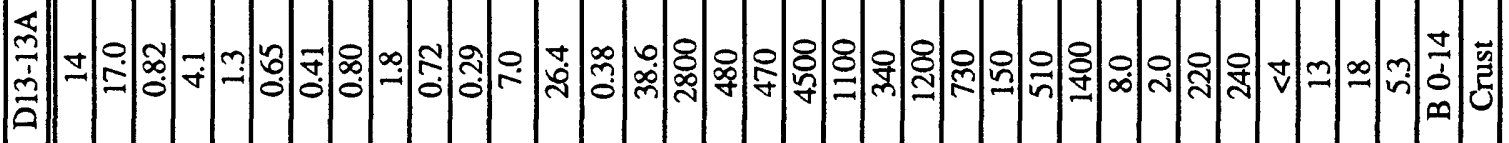



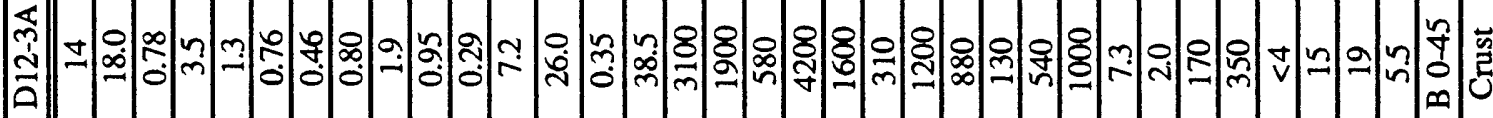

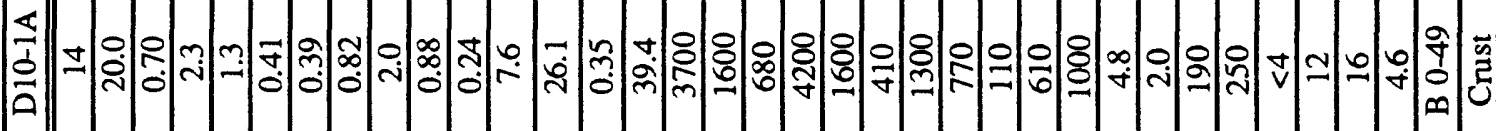

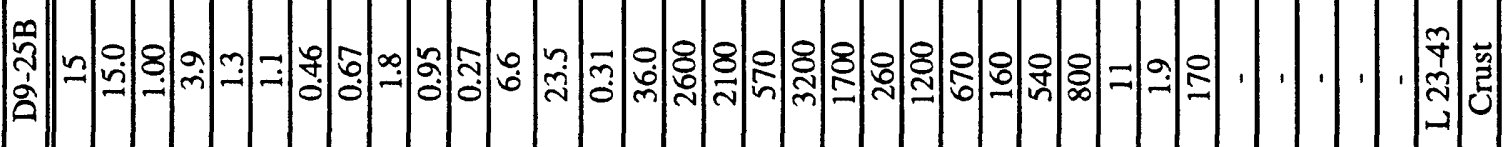

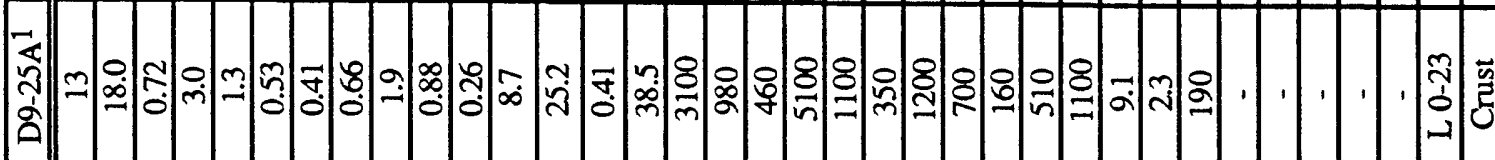

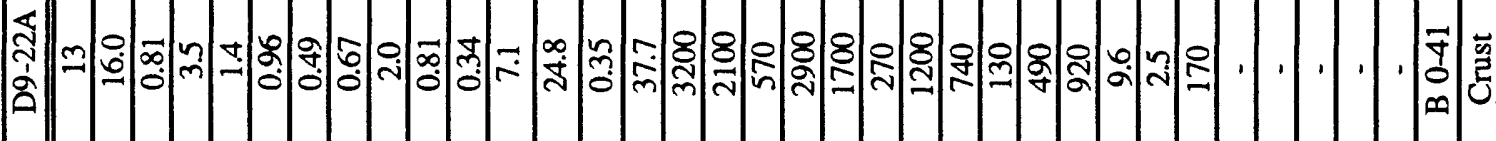

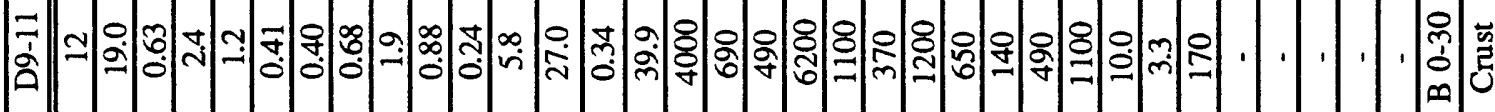

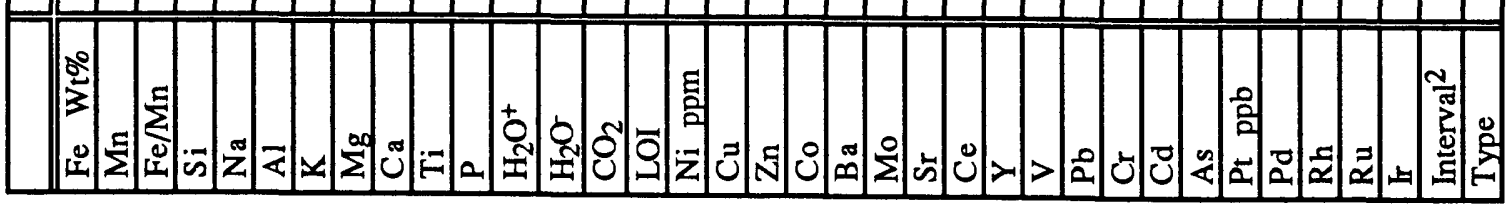


商

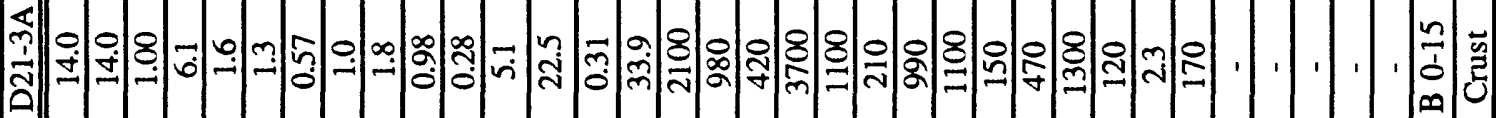

它

勾

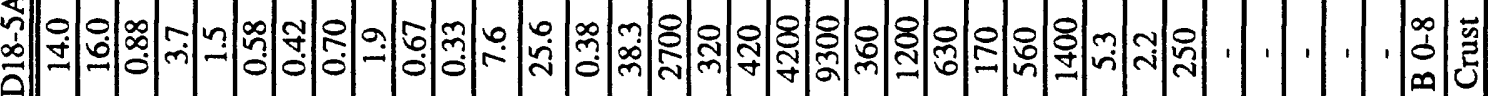

勿

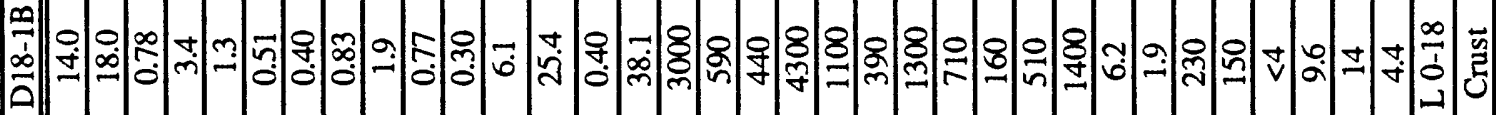

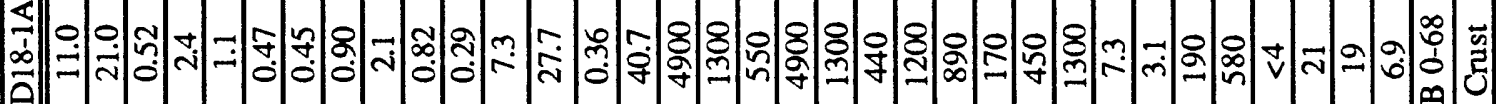

它

尚

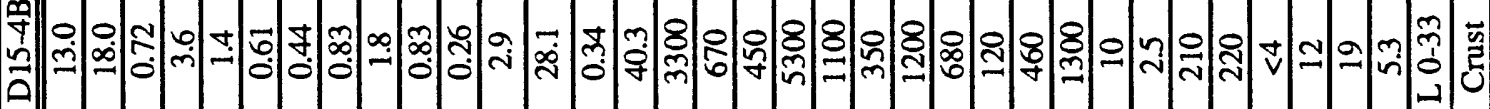

向

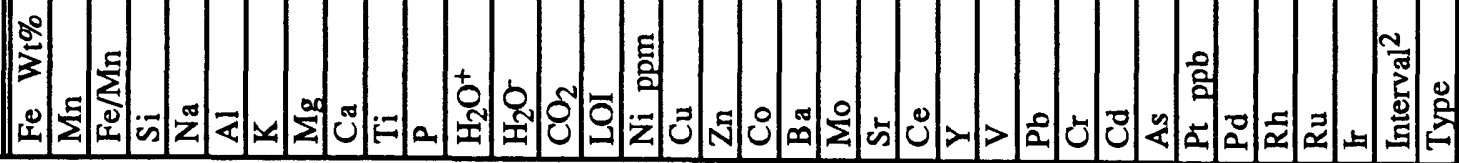




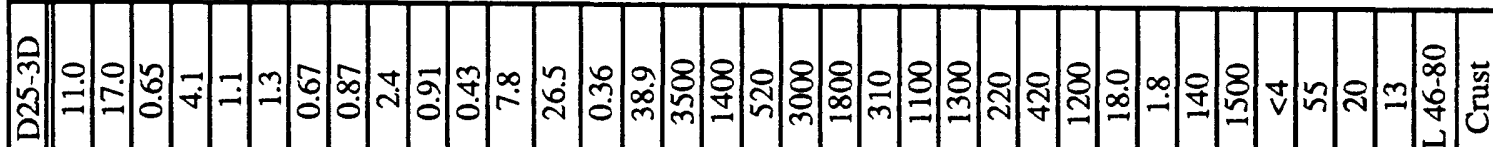

ปิ่

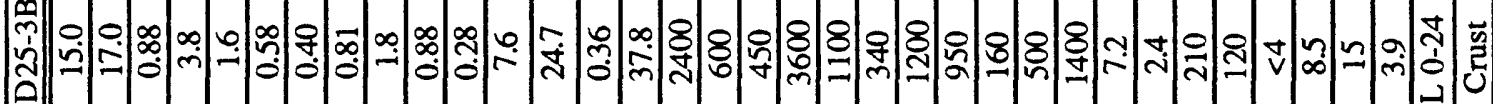

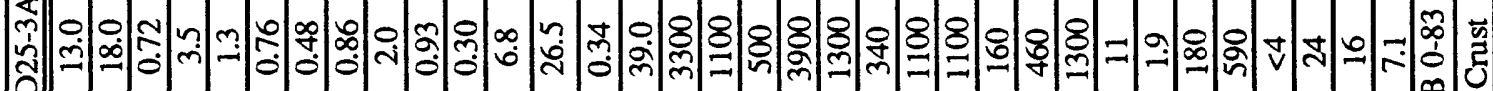

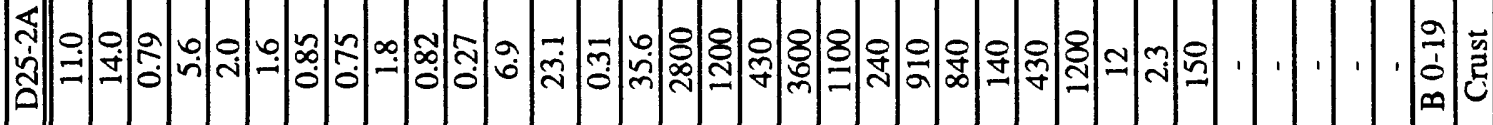

ป்

ป்

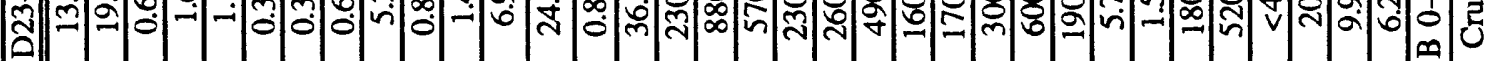

ஸ்

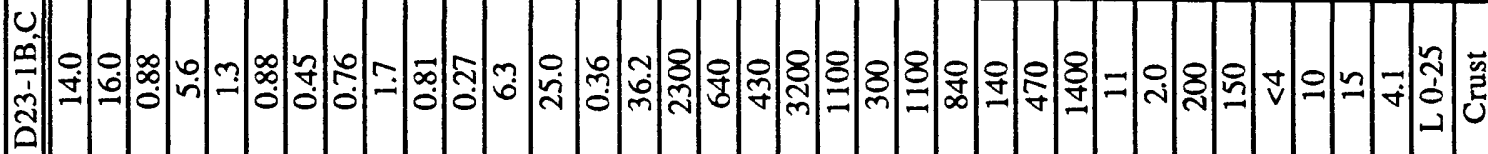

ป்

ஸें

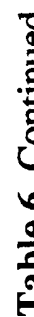

ล்َ

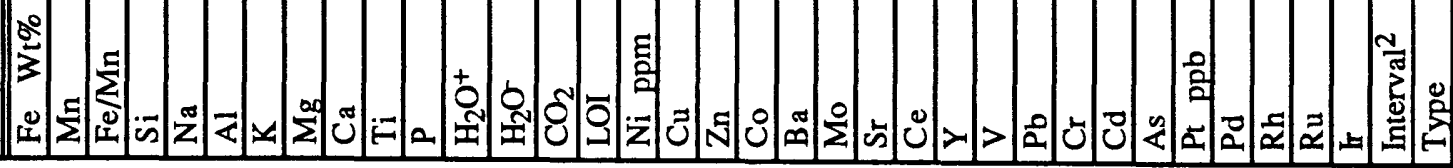




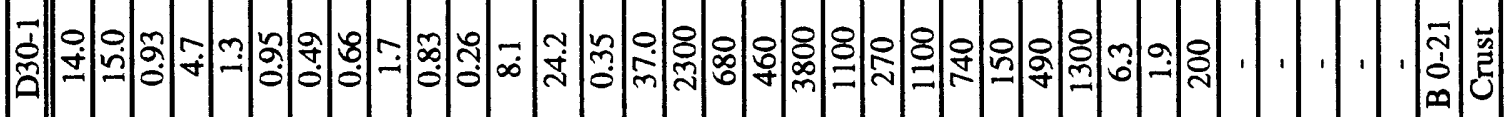

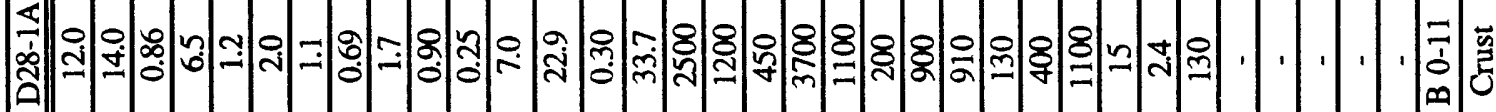

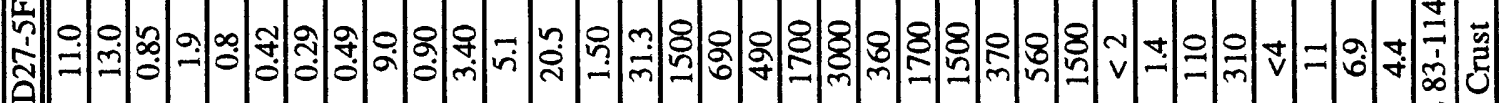

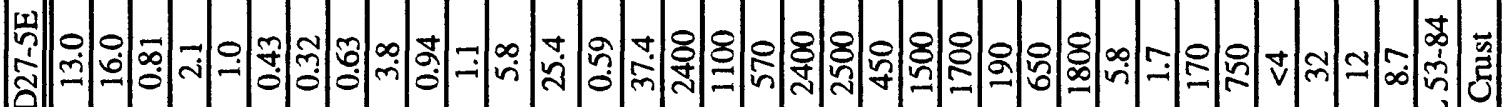

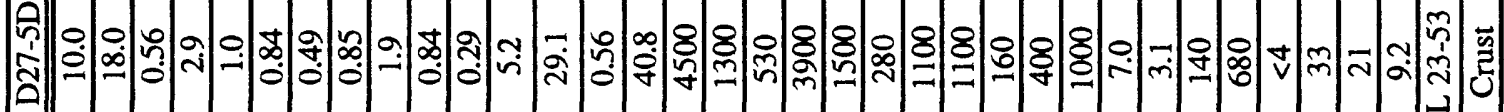

卢

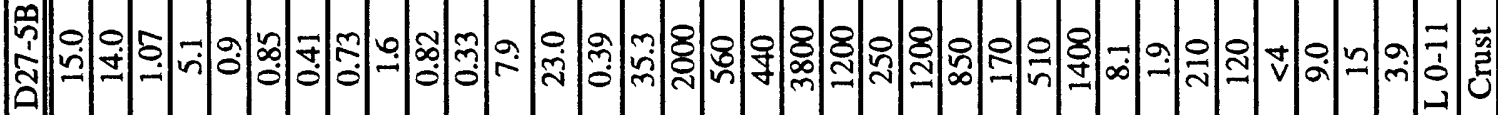

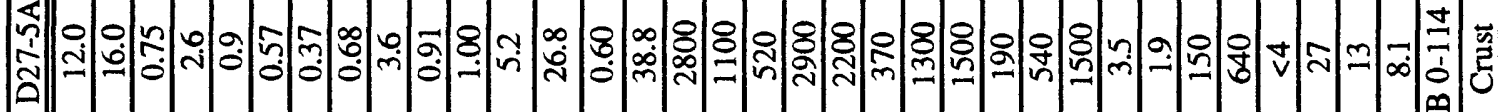

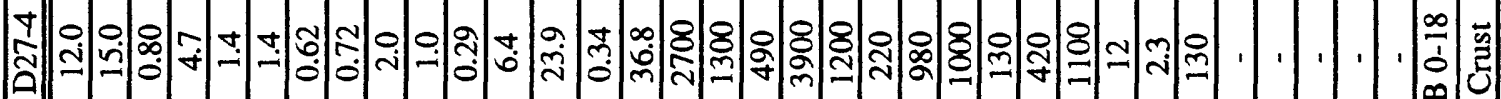

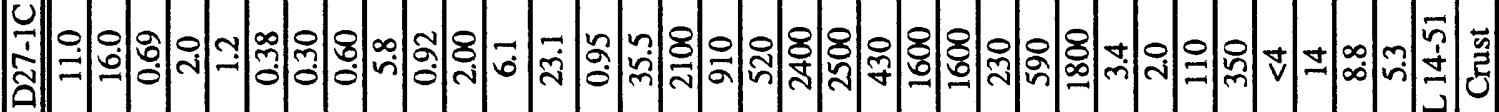

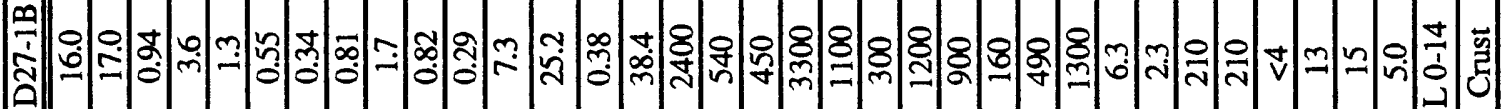

采

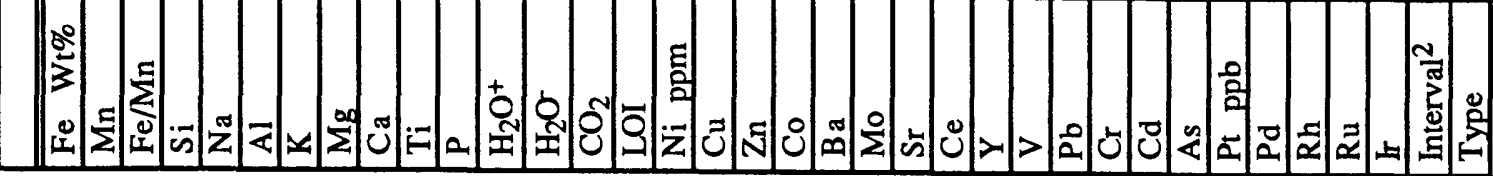




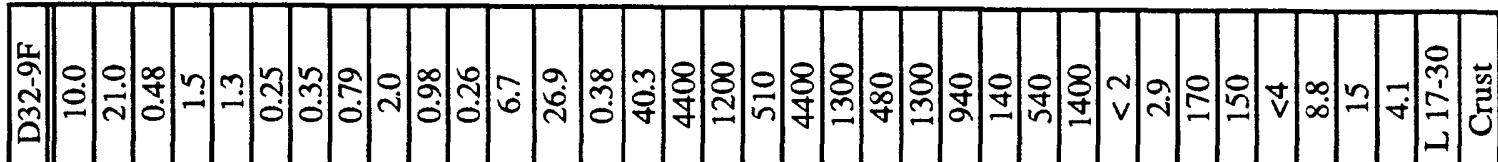
คें 商 商

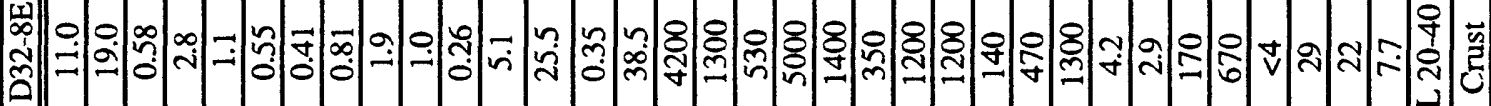

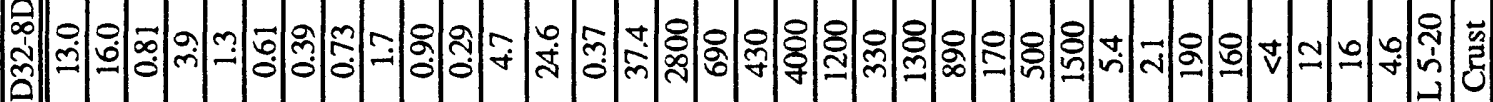
穴

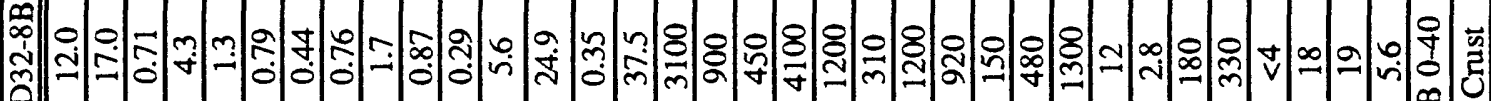
峁

荇

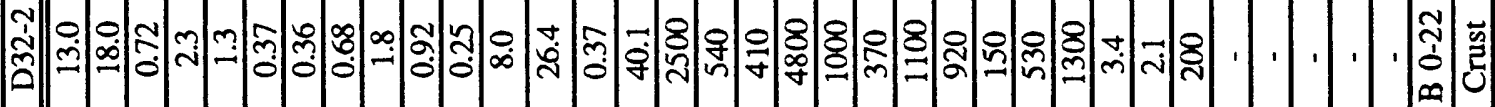

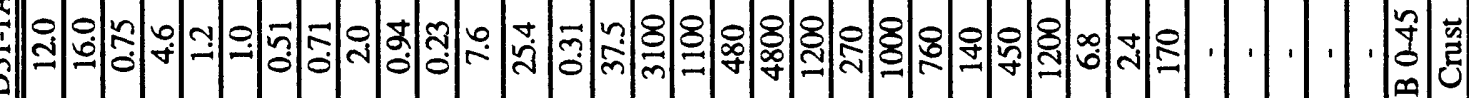

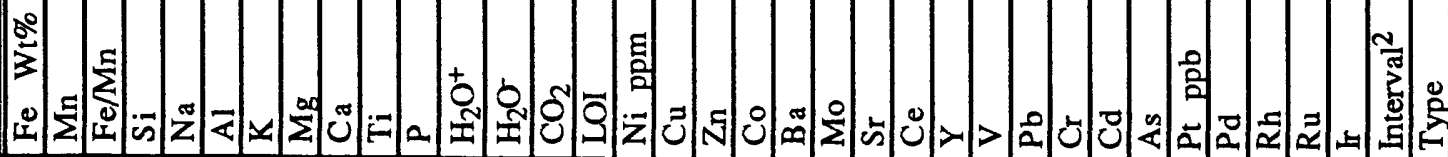




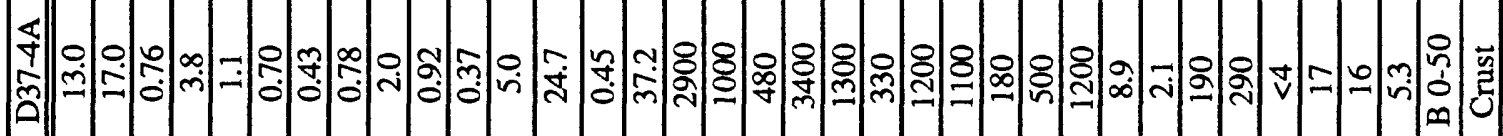

命

ติ

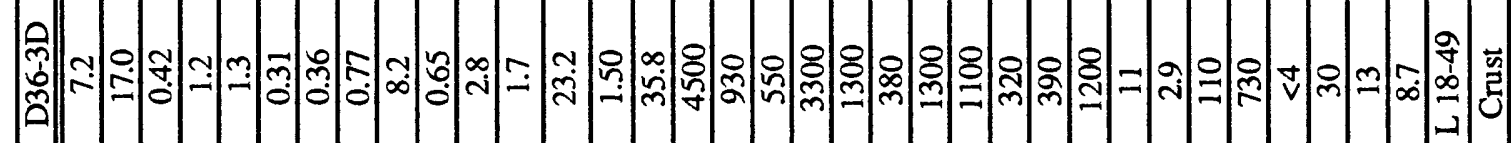

仓ी

它

مि

क்

สీ

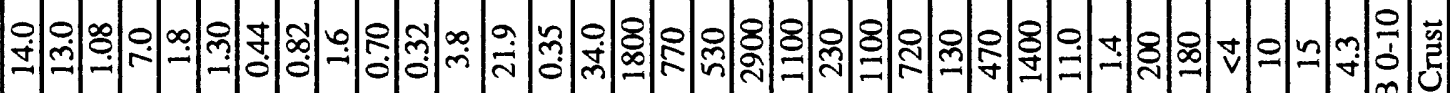

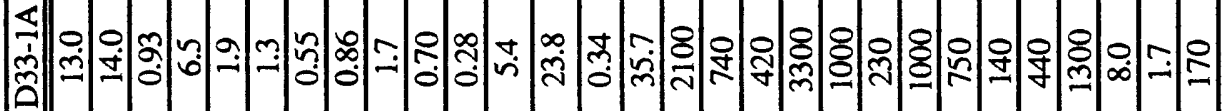

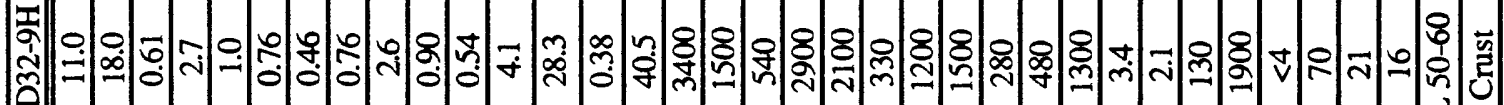

8

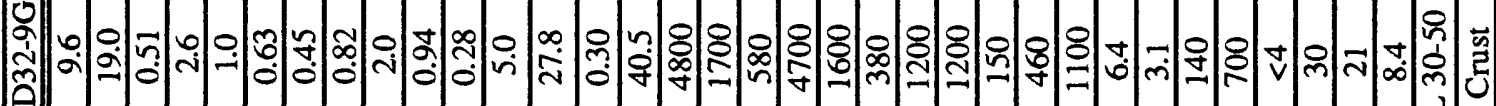

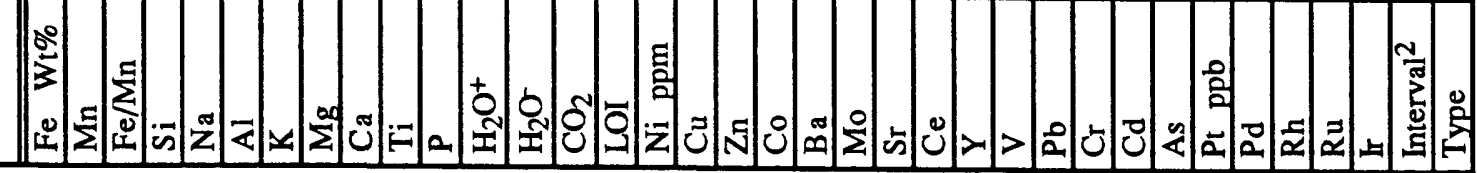




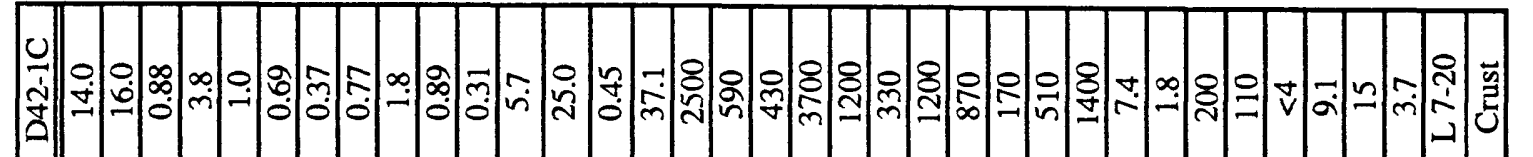

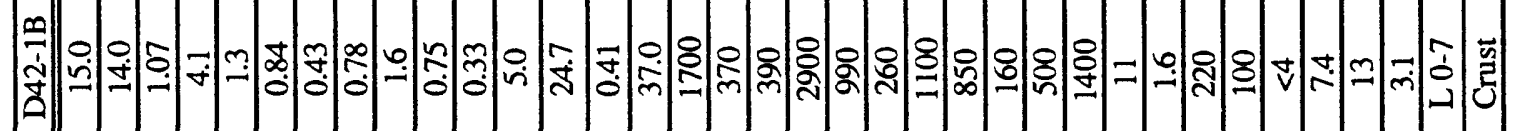

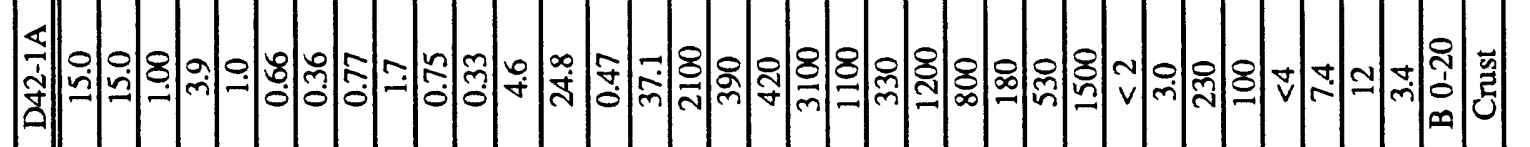

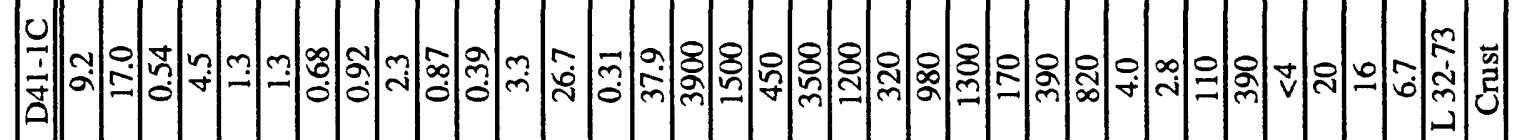

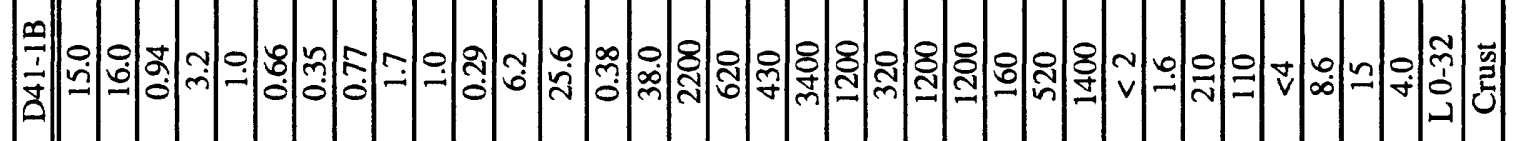

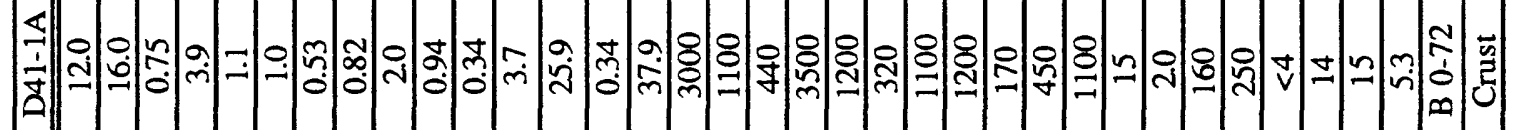

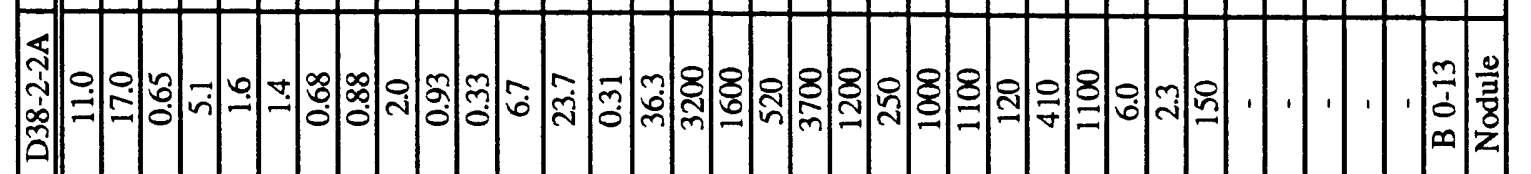

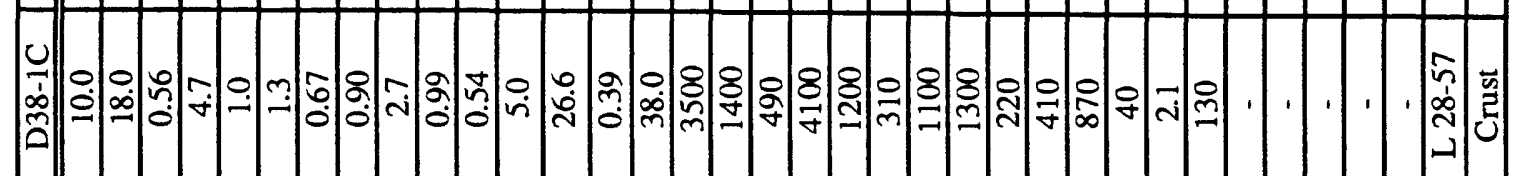

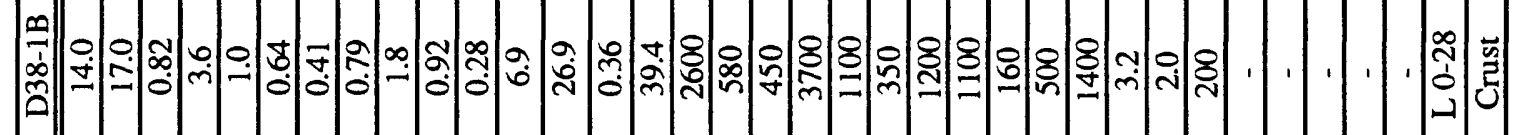

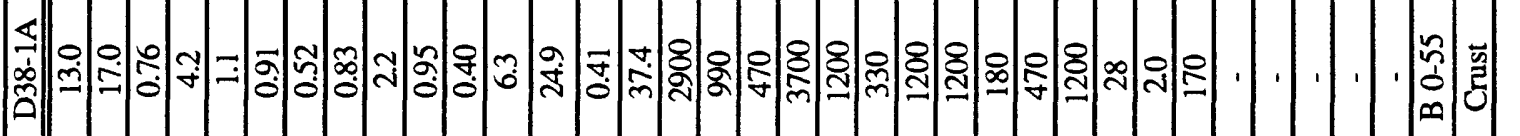

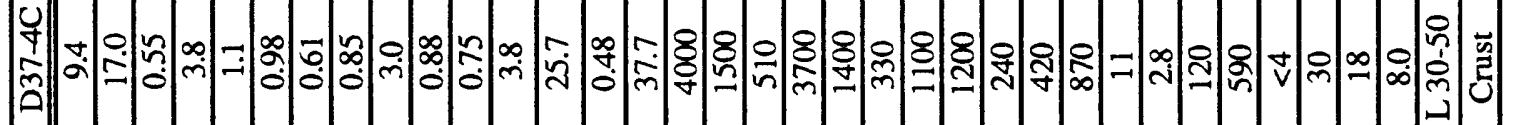

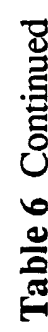

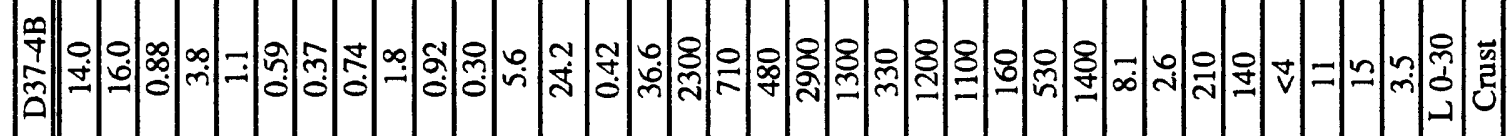

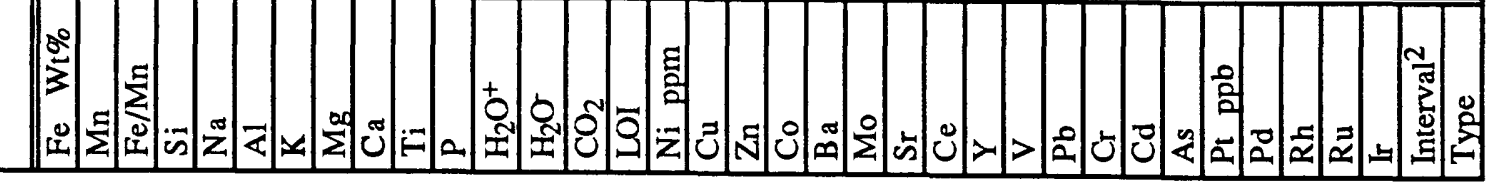

章

造

品

产

岕

丞焉

हैं क्ष

之े है

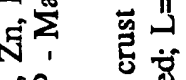

ษิ

형져

×马 苛

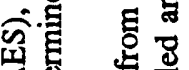

得焉

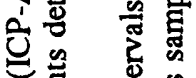

不

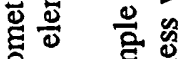

옹 올

品 范

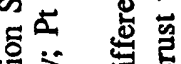

空

岂总范

号点造

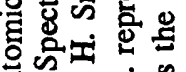

< 0 i

. ส

हैं

垔造

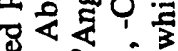

0.000

院它

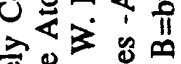

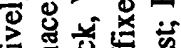

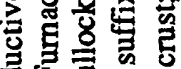

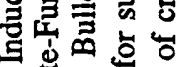

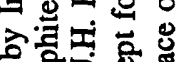

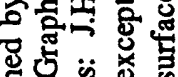

责客步

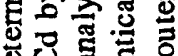

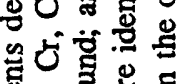

ํㅜㄴ

웜

尔 8

空造

马喀寻

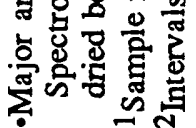




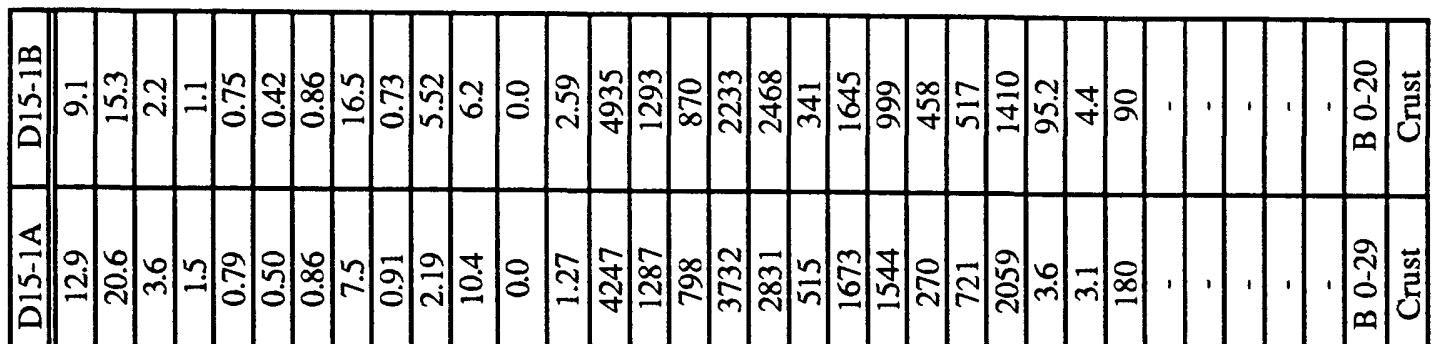

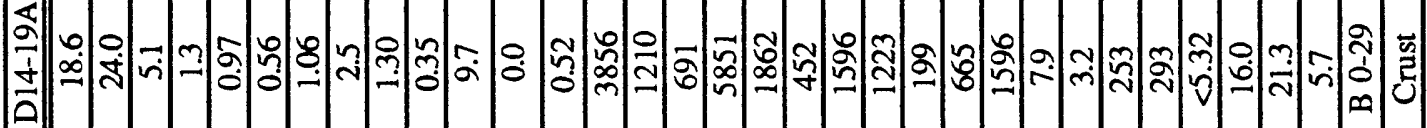

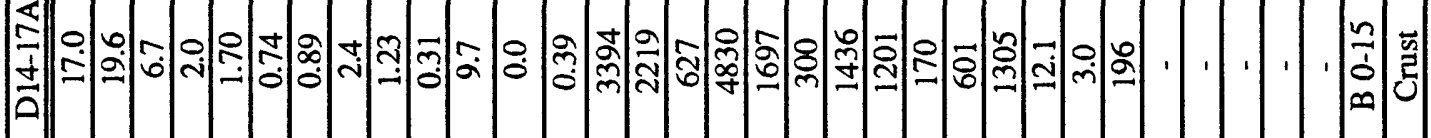

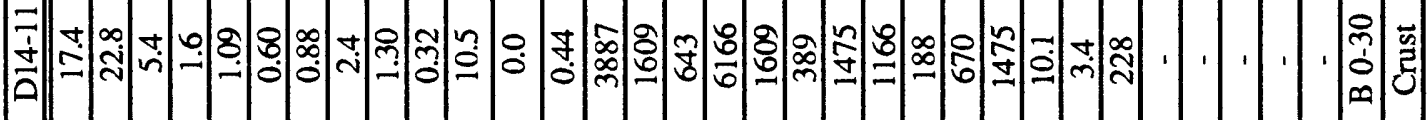

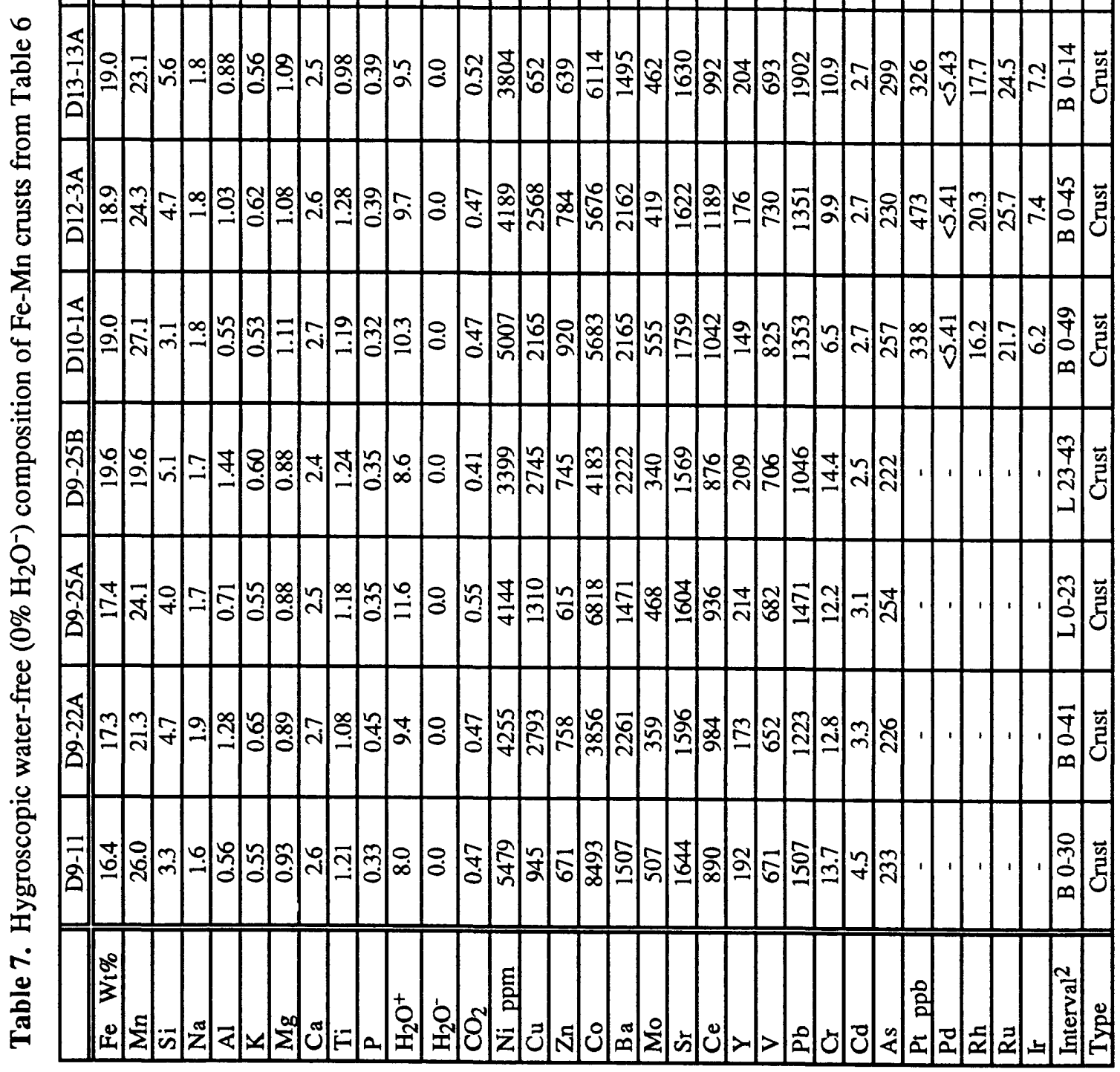




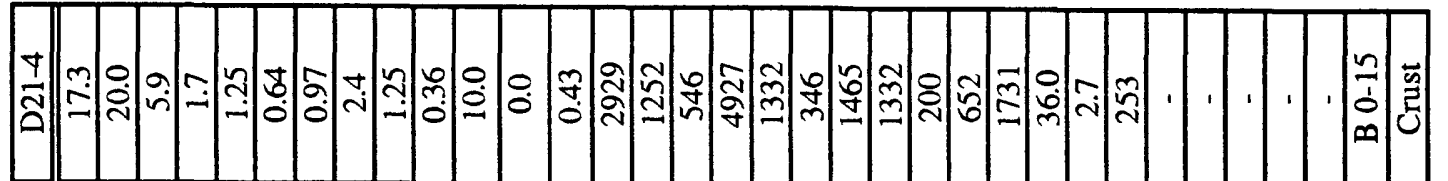

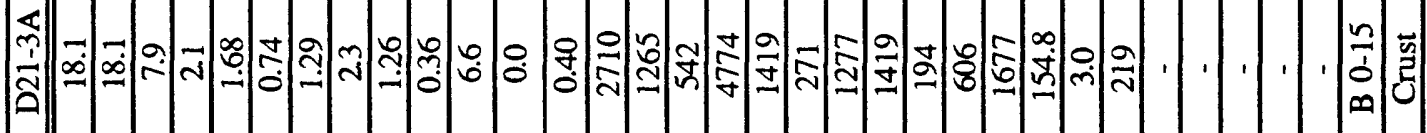

à

立

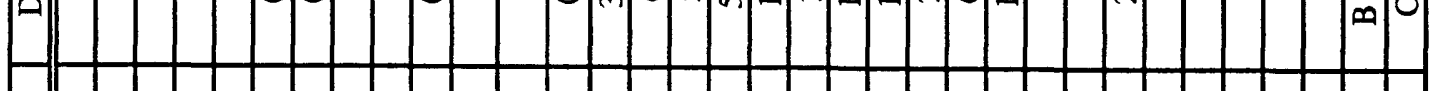

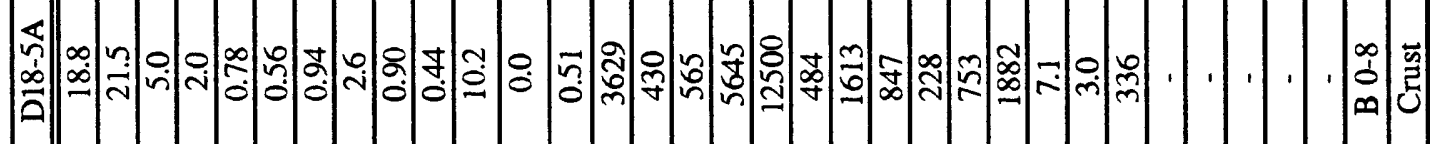

ân

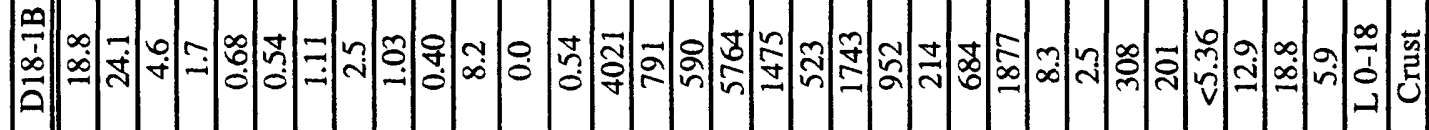

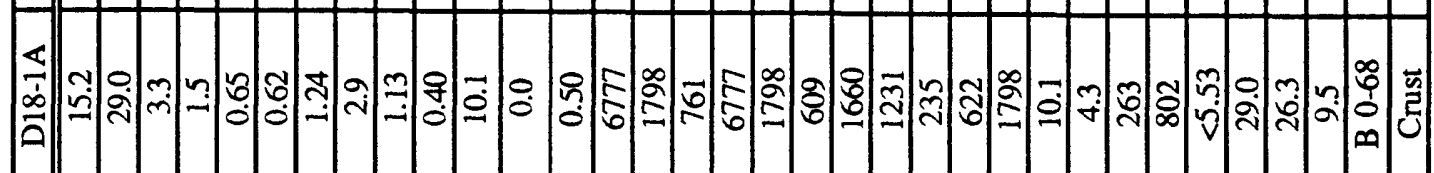

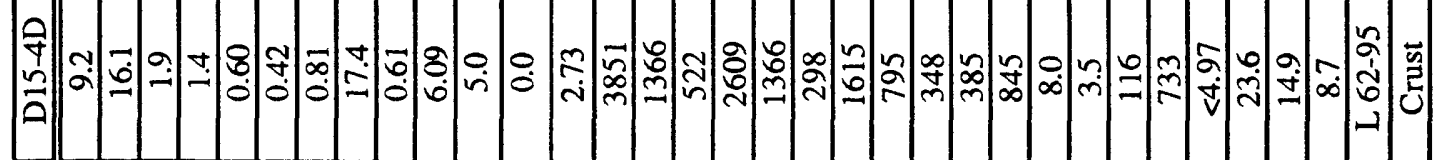

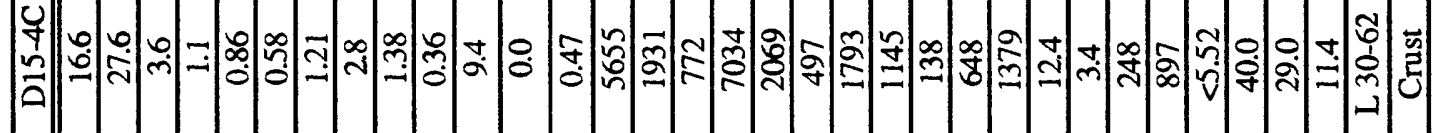

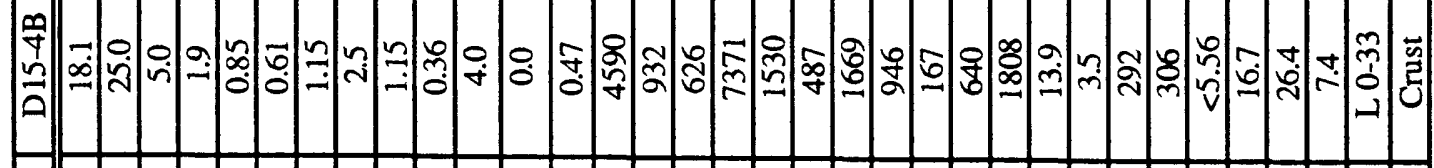

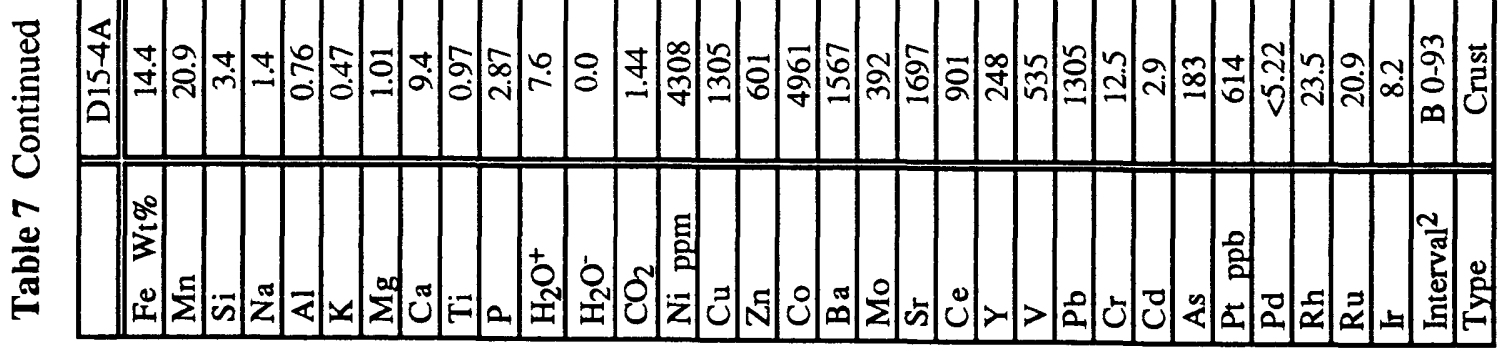




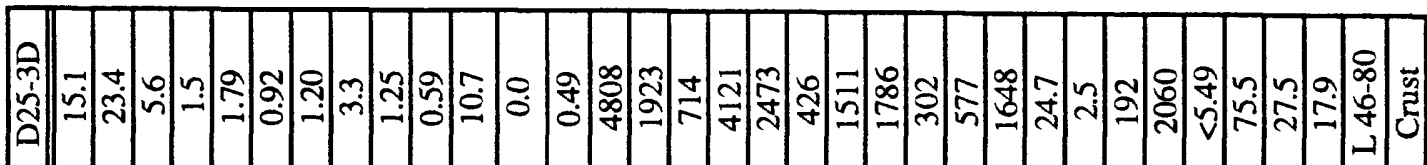

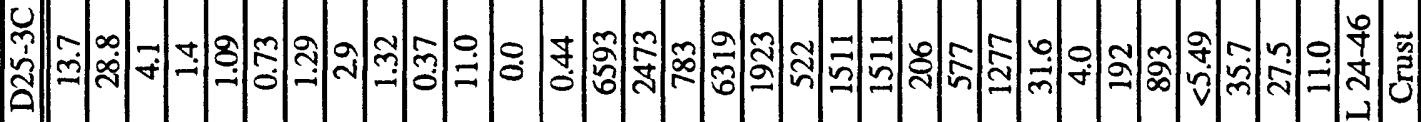

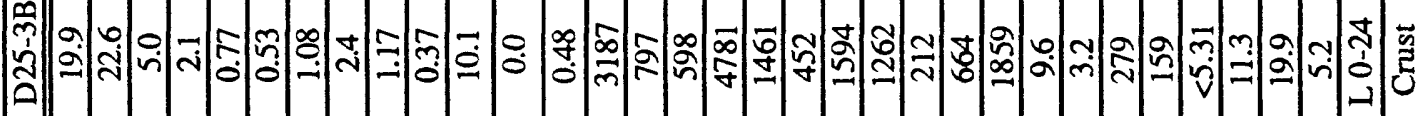

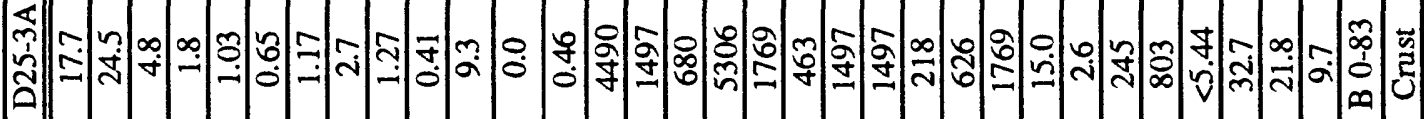

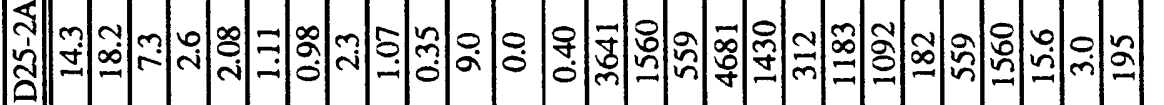

,

ڤ̂́

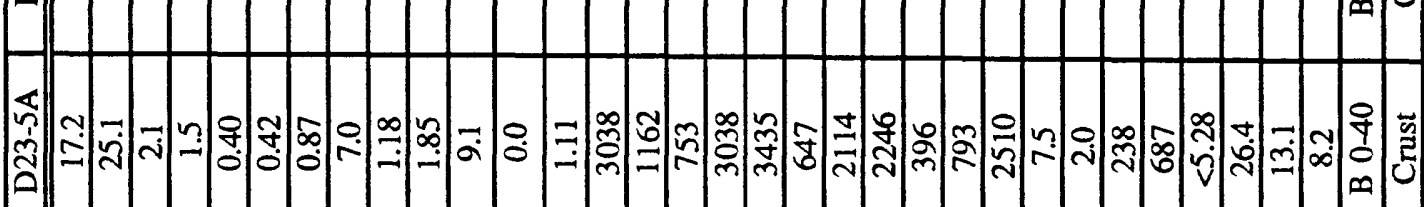

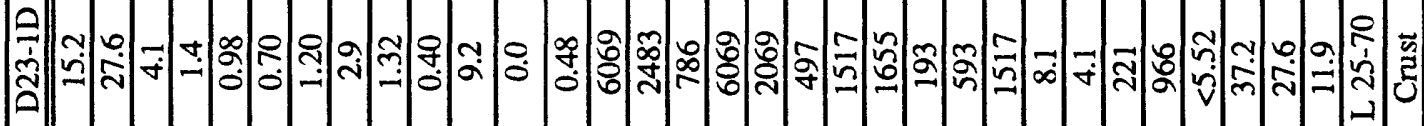

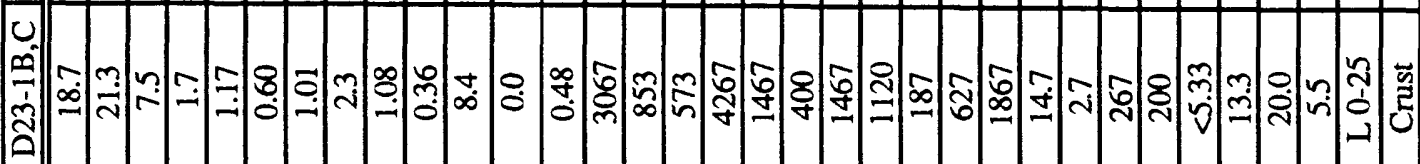

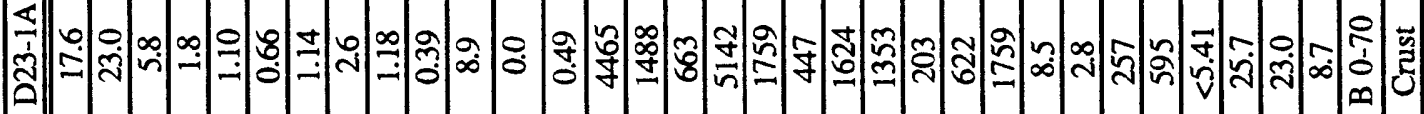

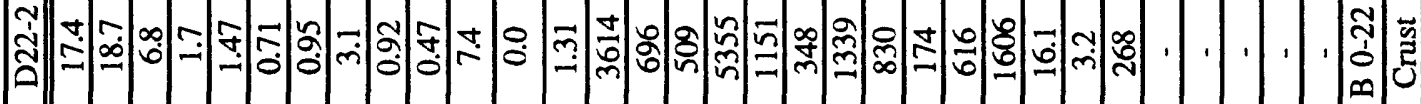

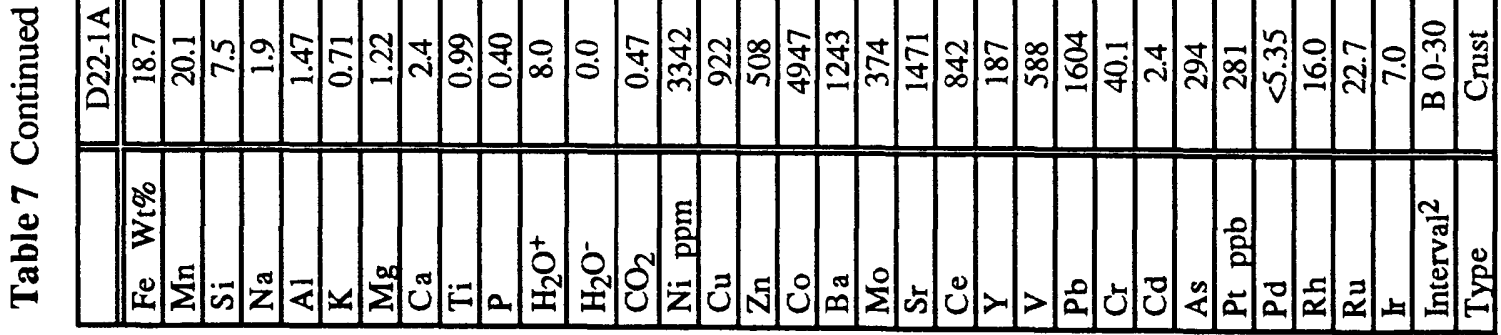


ڤે

究

今)

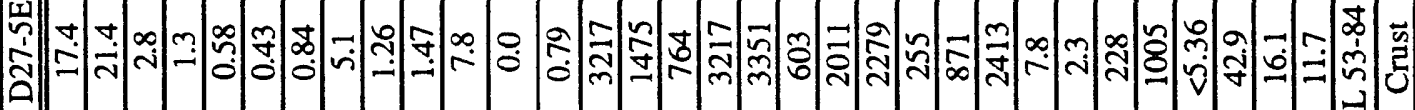

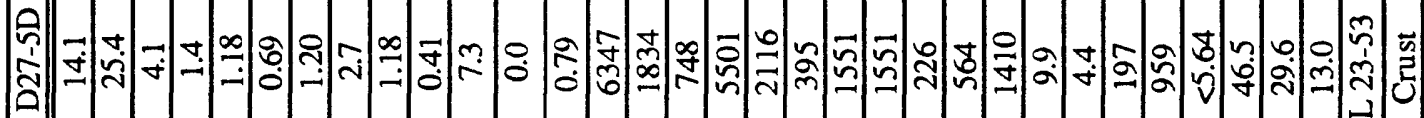

全

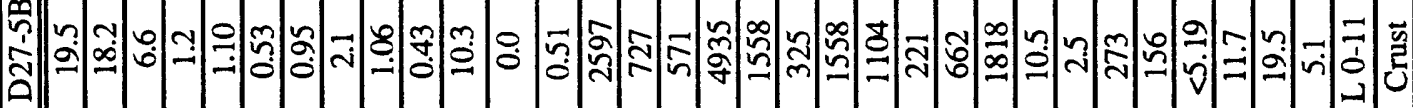

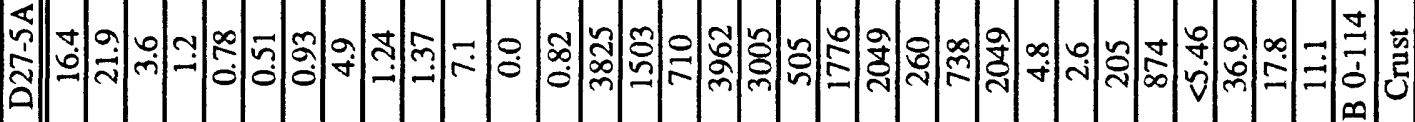

辛

言

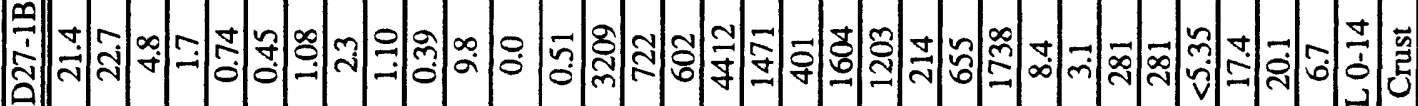

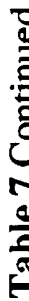

तิ

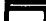

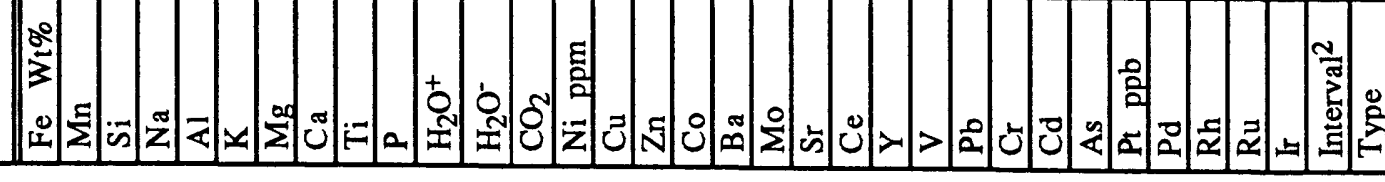




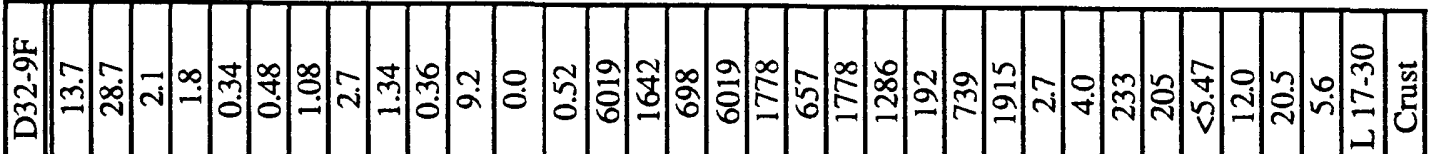

帘

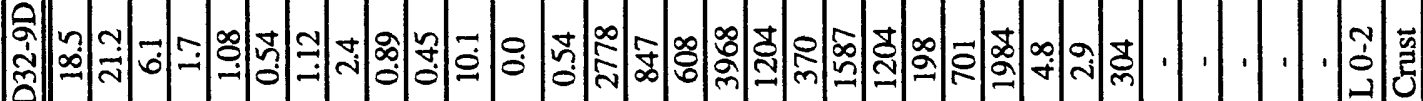

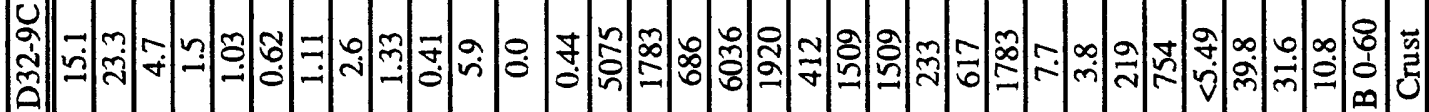

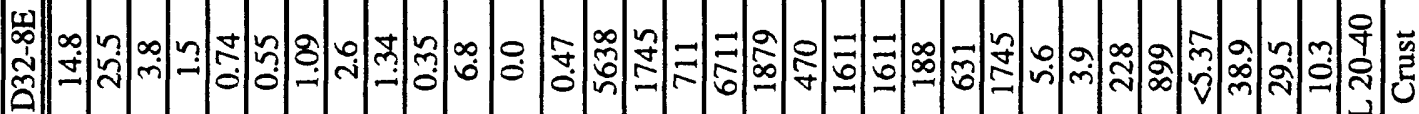

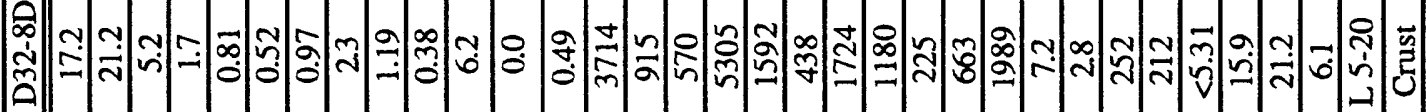

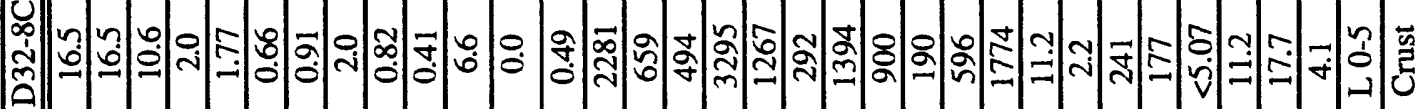

$m$
$\hat{\tilde{n}}$

崩

穴

กิ่

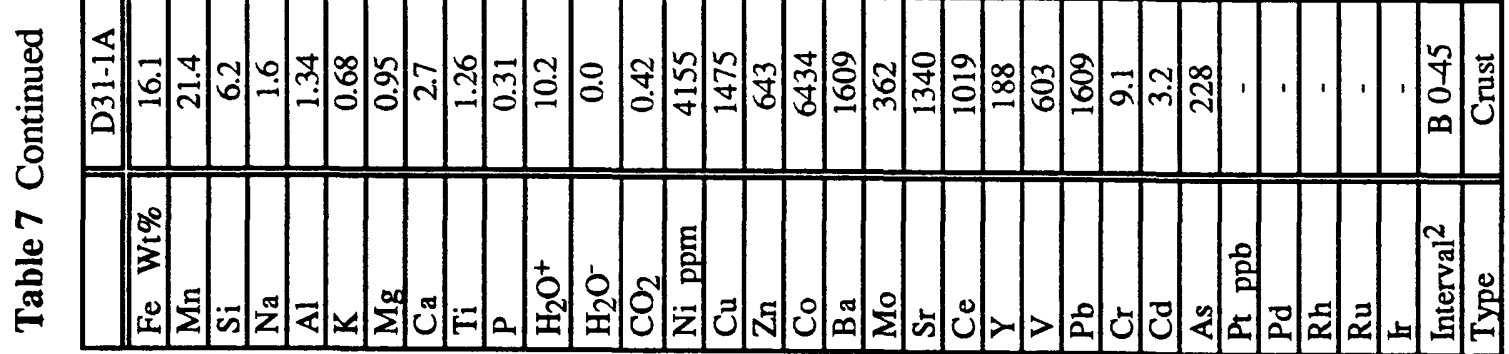




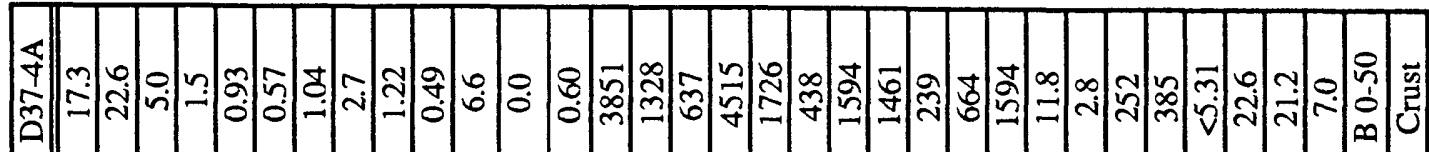

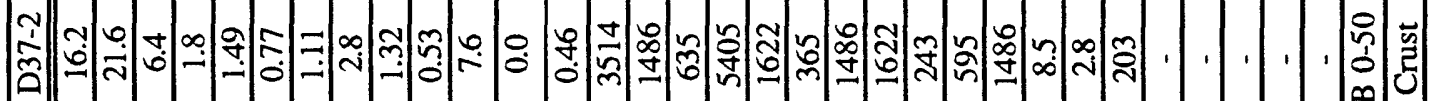

苟

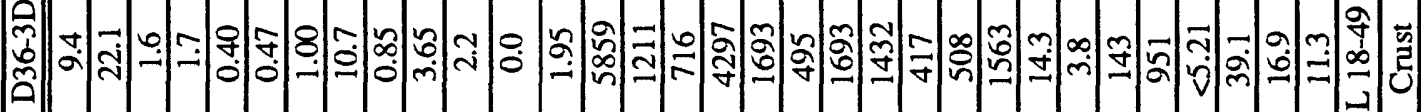

苟

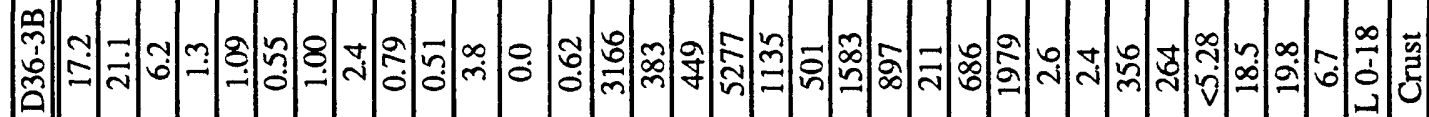

荇

ต́

중

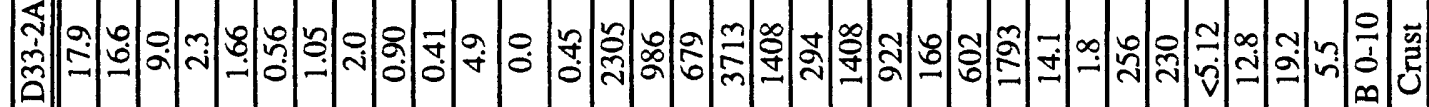

กิ்่

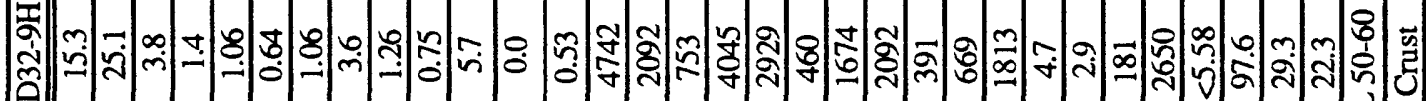



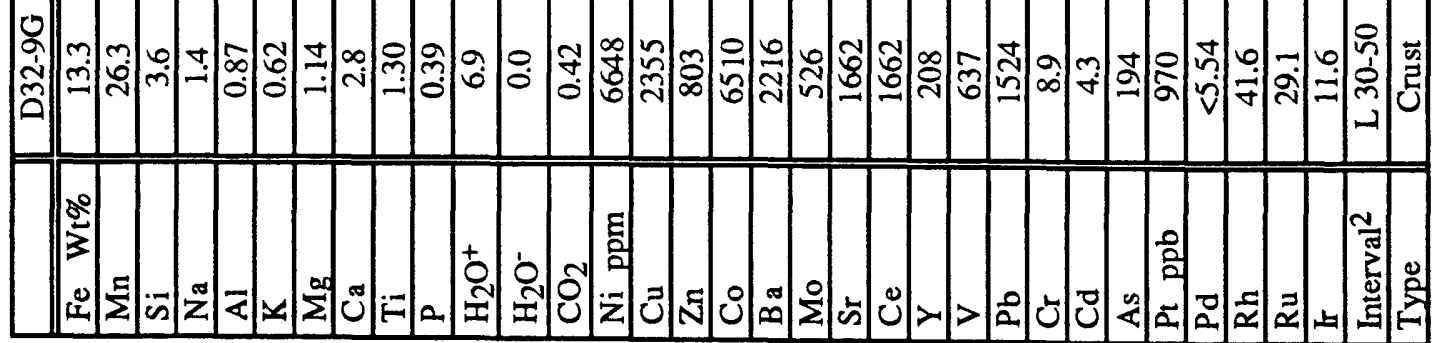




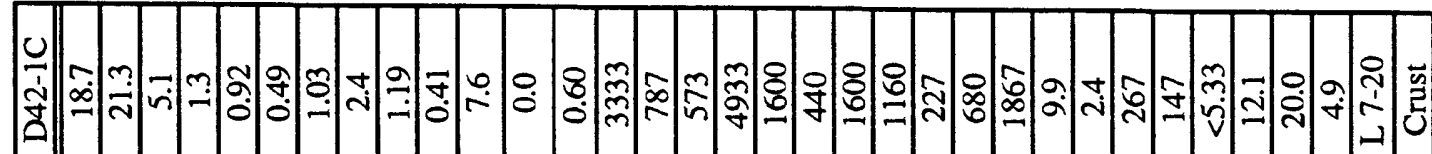

㝘

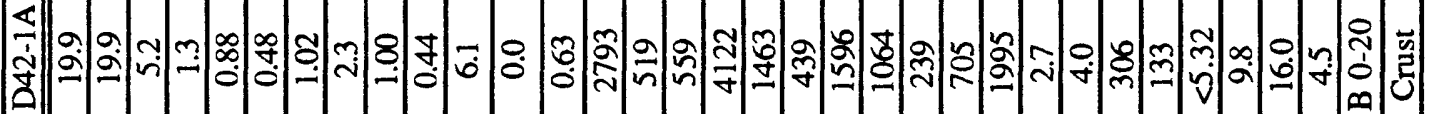

守

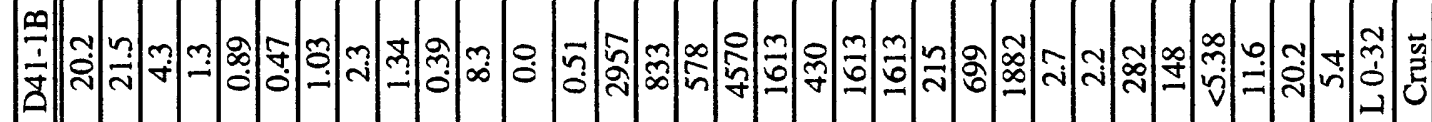

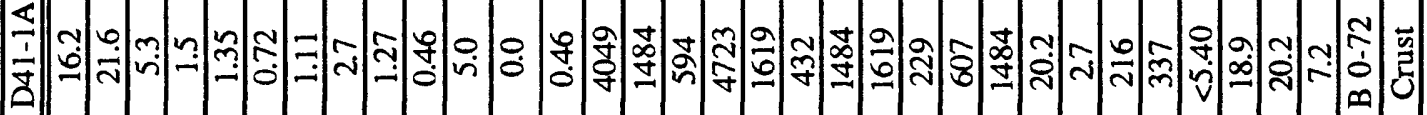

ส

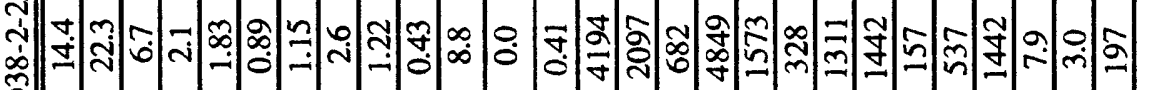

กิ

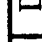

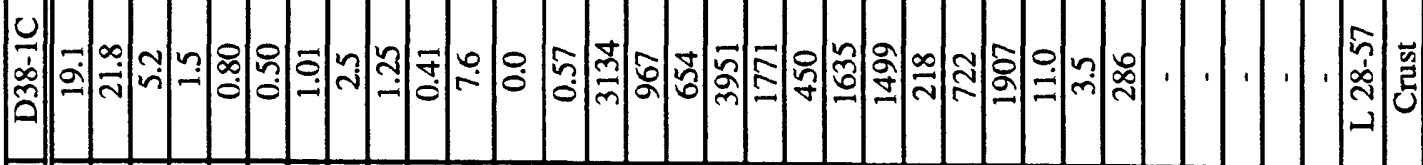

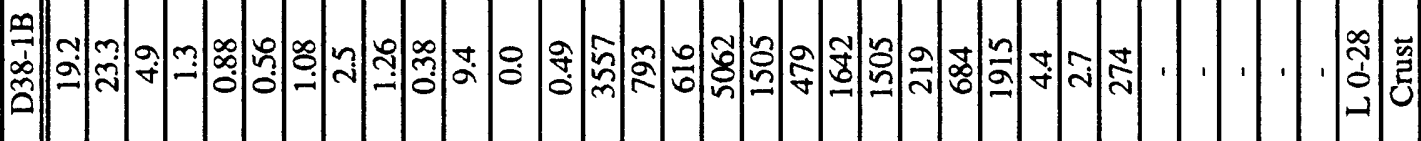

至

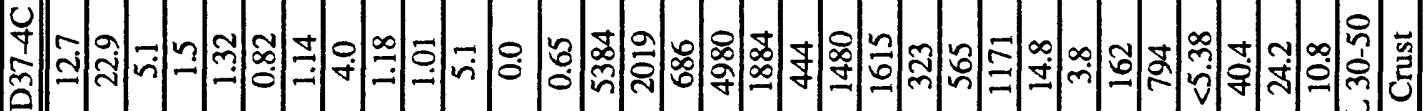

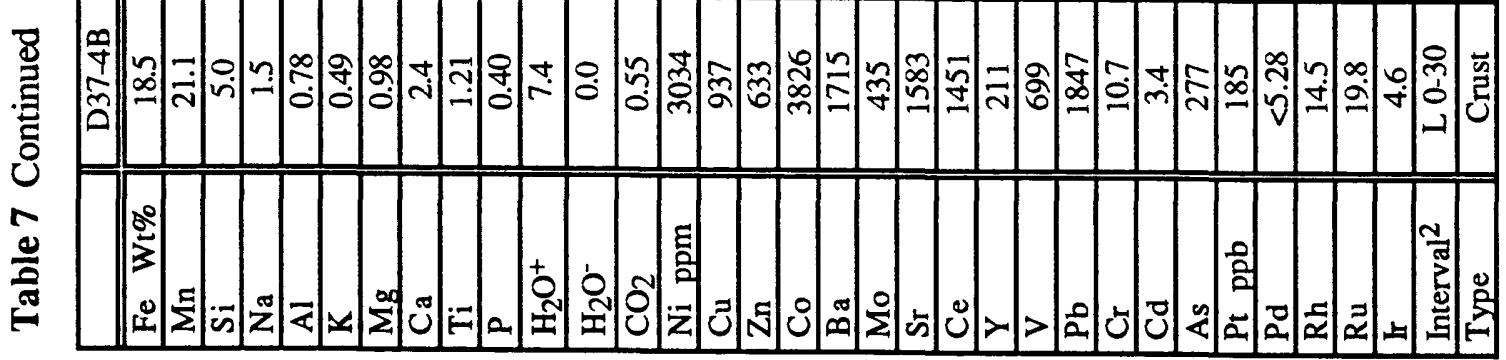


Table 8. Statistics for 46 bulk Fe-Mn crusts from Tunes 6 cruise; data from table 6

\begin{tabular}{|c|c|c|c|c|c|c|}
\hline Element & $\mathbf{N}$ & Mean & Median & $\mathrm{SD}^{1}$ & $\operatorname{Min}^{2}$ & $\operatorname{Max}^{3}$ \\
\hline $\mathrm{Fe} \mathrm{Wt} \mathrm{\%}$ & 46 & 12.4 & 13.0 & 1.46 & 7.7 & 15.0 \\
\hline $\mathrm{Mn}$ & 46 & 16.5 & 16.5 & 1.91 & 13.0 & 21.0 \\
\hline $\mathrm{Fe} / \mathrm{Mn}^{4}$ & 46 & 0.77 & 0.76 & 0.13 & 0.50 & 1.08 \\
\hline $\mathrm{Si}$ & 46 & 4.0 & 3.9 & 1.4 & 1.6 & 7.0 \\
\hline $\mathrm{Na}$ & 46 & 1.3 & 1.3 & 0.2 & 0.9 & 2.0 \\
\hline $\mathrm{Al}$ & 46 & 0.9 & 0.8 & 0.4 & 0.3 & 2.0 \\
\hline K & 46 & 0.48 & 0.46 & 0.13 & 0.31 & 1.10 \\
\hline $\mathrm{Mg}$ & 46 & 0.77 & 0.77 & 0.08 & 0.64 & 1.00 \\
\hline $\mathrm{Ca}$ & 46 & 2.7 & 1.9 & 2.1 & 1.6 & 14.0 \\
\hline $\mathrm{Ti}$ & 46 & 0.85 & 0.88 & 0.11 & 0.62 & 1.00 \\
\hline $\mathrm{P}$ & 46 & 0.57 & 0.30 & 0.76 & 0.23 & 4.70 \\
\hline $\mathrm{H}_{2} \mathrm{O}^{+}$ & 46 & 6.4 & 6.6 & 1.1 & 3.7 & 8.1 \\
\hline $\mathrm{H}_{2} \mathrm{O}^{-}$ & 46 & 24.8 & 24.9 & 2.1 & 14.9 & 27.7 \\
\hline $\mathrm{CO}_{2}$ & 46 & 0.48 & 0.35 & 0.33 & 0.30 & 2.20 \\
\hline LOI & 46 & 37.2 & 37.5 & 2.4 & 26.1 & 40.7 \\
\hline Ni ppm & 46 & 2993 & 2900 & 702 & 1800 & 4900 \\
\hline $\mathrm{Cu}$ & 46 & 1016 & 1000 & 380 & 320 & 2100 \\
\hline $\mathrm{Zn}$ & 46 & 493 & 480 & 73 & 380 & 740 \\
\hline Co & 46 & 3802 & 3800 & 739 & 1900 & 6200 \\
\hline $\mathrm{Ba}$ & 46 & 1498 & 1200 & 1235 & 860 & 9300 \\
\hline Mo & 46 & 316 & 310 & 70 & 200 & 490 \\
\hline $\mathrm{Sr}$ & 46 & 1158 & 1100 & 135 & 900 & 1600 \\
\hline $\mathrm{Ce}$ & 46 & 950 & 920 & 230 & 620 & 1700 \\
\hline Y & 46 & 166 & 150 & 50 & 110 & 390 \\
\hline V & 46 & 483 & 480 & 47 & 400 & 610 \\
\hline $\mathrm{Pb}$ & 46 & 1270 & 1300 & 183 & 920 & 1900 \\
\hline $\mathrm{Cr}$ & 45 & 13 & 7 & 20 & 2 & 120 \\
\hline $\mathrm{Cd}$ & 46 & 2.0 & 2.3 & 0.5 & 1.4 & 8.1 \\
\hline As & 46 & 176 & 175 & 29 & 77 & 250 \\
\hline Pt ppb & 19 & 373 & 350 & 159 & 100 & 640 \\
\hline $\mathrm{Pd}$ & 19 & $<4$ & $<4$ & 0 & $<4$ & $<4$ \\
\hline Rh & 19 & 17.2 & 17.0 & 5.9 & 7.4 & 29.0 \\
\hline $\mathrm{Ru}$ & 19 & 15.9 & 16.0 & 3.1 & 9.9 & 23.0 \\
\hline Ir & 19 & 5.8 & 5.6 & 1.3 & 3.4 & 8.1 \\
\hline Depth $^{5}$ & 46 & 1450 & 7238 & 2261 & 1450 & 13025 \\
\hline Thickness 6 & 46 & 40 & 59 & 26 & 3 & 114 \\
\hline
\end{tabular}

${ }^{1}$ Standard deviation; ${ }^{2}$ Minimum; ${ }^{3}$ Maximum; ${ }^{4}$ Ratio of the Fe and Mn means, not a mean of the summation of ratios; ${ }^{5}$ Water depth in meters; ${ }^{6}$ Crust thickness in millimeters 
Table 9. Statistics for 46 bulk Fe-Mn crusts from Tunes 6 cruise; data from table 7 (hygroscopic water-free)

\begin{tabular}{|c|c|c|c|c|c|c|}
\hline Element & $\mathbf{N}$ & Mean & Median & $\mathrm{SD}^{1}$ & $\operatorname{Min}^{2}$ & $\operatorname{Max}^{3}$ \\
\hline Fe Wt\% & 46 & 16.7 & 17.2 & 1.7 & 12.9 & 19.9 \\
\hline $\mathrm{Mn}$ & 46 & 22.1 & 22.1 & 2.8 & 16.6 & 29.0 \\
\hline $\mathrm{Si}$ & 46 & 5.4 & 5.3 & 1.7 & 2.1 & 9.0 \\
\hline $\mathrm{Na}$ & 46 & 1.7 & 1.7 & 0.3 & 1.2 & 2.6 \\
\hline $\mathrm{Al}$ & 46 & 1.15 & 1.07 & 0.46 & 0.40 & 2.59 \\
\hline $\mathrm{K}$ & 46 & 0.65 & 0.62 & 0.17 & 0.41 & 1.43 \\
\hline $\mathrm{Mg}$ & 46 & 1.02 & 1.02 & 0.11 & 0.85 & 1.29 \\
\hline $\mathrm{Ca}$ & 46 & 3.2 & 2.6 & 1.6 & 2.0 & 9.4 \\
\hline $\mathrm{Ti}$ & 46 & 1.14 & 1.18 & 0.14 & 0.90 & 1.34 \\
\hline $\mathrm{P}$ & 46 & 0.63 & 0.40 & 0.58 & 0.31 & 2.87 \\
\hline $\mathrm{H}_{2} \mathrm{O}^{+}$ & 46 & 8.6 & 9.0 & 1.6 & 4.9 & 11.6 \\
\hline $\mathrm{CO}_{2}$ & 46 & 0.59 & 0.47 & 0.28 & 0.39 & 1.44 \\
\hline $\mathrm{Ni} \mathrm{ppm}$ & 46 & 3992 & 3875 & 960 & 2305 & 6777 \\
\hline $\mathrm{Cu}$ & 46 & 1369 & 1323 & 499 & 430 & 2793 \\
\hline $\mathrm{Zn}$ & 46 & 652 & 643 & 86 & 508 & 920 \\
\hline Co & 46 & 5177 & 5023 & 1002 & 3038 & 8493 \\
\hline $\mathrm{Ba}$ & 46 & 1978 & 1610 & 1656 & 1151 & 12500 \\
\hline Mo & 46 & 422 & 416 & 98 & 259 & 647 \\
\hline $\mathrm{Sr}$ & 46 & 1538 & 1506 & 183 & 1167 & 2114 \\
\hline $\mathrm{Ce}$ & 46 & 1260 & 1224 & 315 & 830 & 2246 \\
\hline$Y$ & 46 & 215 & 202 & 50 & 149 & 396 \\
\hline V & 46 & 645 & 635 & 65 & 519 & 825 \\
\hline $\mathrm{Pb}$ & 46 & 1689 & 1711 & 245 & 1223 & 2510 \\
\hline $\mathrm{Cr}$ & 46 & 15.3 & 10.1 & 22.5 & 2.7 & 154.8 \\
\hline $\mathrm{Cd}$ & 46 & 3.1 & 3.0 & 0.6 & 1.8 & 4.5 \\
\hline As & 46 & 237 & 236 & 34 & 169 & 336 \\
\hline $\mathrm{Pt} \mathrm{ppb}$ & 19 & 501 & 473 & 218 & 133 & 874 \\
\hline $\mathrm{Pd}$ & 19 & $<5.36$ & $<5.35$ & 0.10 & $<5.12$ & $<5.53$ \\
\hline $\mathrm{Rh}$ & 19 & 23.2 & 22.6 & 8.1 & 9.8 & 39.8 \\
\hline $\mathrm{Ru}$ & 19 & 21.3 & 21.3 & 4.4 & 13.1 & 31.6 \\
\hline Ir & 19 & 7.8 & 7.5 & 1.8 & 4.5 & 11.1 \\
\hline Depth $^{4}$ & 46 & 1450 & 7238 & 2261 & 1450 & 13025 \\
\hline Thickness 5 & 46 & 40 & 59 & 26 & 3 & 114 \\
\hline
\end{tabular}

${ }^{1}$ Standard deviation; ${ }^{2}$ Minimum; ${ }^{3}$ Maximum; ${ }^{4}$ Ratio of the Fe and Mn means, not a mean of the summation of ratios; ${ }^{5}$ Water depth in meters; ${ }^{6}$ Crust thickness in millimeters 
Table 10. Statistics for $38 \mathrm{Fe}-\mathrm{Mn}$ crust layers from the Tunes 6 cruise; data from table 7 (hygroscopic water-free)

\begin{tabular}{|c|c|c|c|c|c|c|}
\hline Element & $\mathbf{N}$ & Mean & Median & $\mathrm{SD}^{1}$ & $\operatorname{Min}^{2}$ & $\operatorname{Max}^{3}$ \\
\hline Fe Wt. \% & 38 & 16.2 & 16.9 & 3.2 & 9.1 & 21.4 \\
\hline $\mathrm{Mn}$ & 38 & 22.6 & 22.4 & 3.6 & 15.3 & 30.9 \\
\hline $\mathrm{Fe} / \mathrm{Mn}^{4}$ & 38 & 0.7 & 0.8 & 0.2 & 0.4 & 1.1 \\
\hline $\mathrm{Si}$ & 38 & 4.6 & 4.9 & 1.8 & 1.6 & 10.6 \\
\hline $\mathrm{Na}$ & 38 & 1.5 & 1.5 & 0.2 & 1.0 & 2.1 \\
\hline $\mathrm{Al}$ & 38 & 0.93 & 0.88 & 0.36 & 0.34 & 1.79 \\
\hline $\mathrm{K}$ & 38 & 0.57 & 0.55 & 0.13 & 0.36 & 0.93 \\
\hline Mg & 38 & 1.04 & 1.05 & 0.15 & 0.62 & 1.31 \\
\hline $\mathrm{Ca}$ & 38 & 4.0 & 2.5 & 3.7 & 2.0 & 17.4 \\
\hline $\mathrm{Ti}$ & 38 & 1.15 & 1.19 & 0.19 & 0.61 & 1.45 \\
\hline$P$ & 38 & 0.99 & 0.41 & 1.45 & 0.32 & 6.09 \\
\hline $\mathrm{H}_{2} \mathrm{O}^{+}$ & 38 & 7.7 & 7.8 & 2.1 & 2.2 & 11.0 \\
\hline $\mathrm{CO}_{2}$ & 38 & 0.73 & 0.52 & 0.58 & 0.38 & 2.73 \\
\hline $\mathrm{Ni} \mathrm{ppm}$ & 38 & 4209 & 3783 & 1492 & 1887 & 8158 \\
\hline $\mathrm{Cu}$ & 38 & 1332 & 1161 & 641 & 383 & 2745 \\
\hline $\mathrm{Zn}$ & 38 & 654 & 630 & 100 & 449 & 870 \\
\hline Co & 38 & 4837 & 4857 & 1380 & 2138 & 8298 \\
\hline $\mathrm{Ba}$ & 38 & 1887 & 1728 & 603 & 1135 & 3774 \\
\hline Mo & 38 & 453 & 451 & 92 & 276 & 657 \\
\hline $\mathrm{Sr}$ & 38 & 1639 & 1612 & 163 & 1337 & 2138 \\
\hline $\mathrm{Ce}$ & 38 & 1374 & 1339 & 366 & 795 & 2279 \\
\hline $\mathbf{Y}$ & 38 & 243 & 214 & 78 & 138 & 465 \\
\hline V & 38 & 647 & 659 & 86 & 385 & 871 \\
\hline $\mathrm{Pb}$ & 38 & 1722 & 1816 & 332 & 845 & 2413 \\
\hline $\mathrm{Cr}$ & 38 & 12.1 & 9.7 & 15.0 & 2.5 & 95.2 \\
\hline $\mathrm{Cd}$ & 38 & 3.2 & 3.0 & 0.8 & 1.8 & 4.8 \\
\hline As & 38 & 233 & 240 & 61 & 90 & 356 \\
\hline $\mathrm{Pt} \mathrm{ppb}$ & 33 & 612 & 447 & 566 & 133 & 2650 \\
\hline Pd & 33 & $<5.36$ & $<5.36$ & 0.2 & $<4.97$ & $<5.64$ \\
\hline $\mathrm{Rh}$ & 33 & 27.7 & 18.5 & 19.6 & 9.8 & 97.6 \\
\hline $\mathrm{Ru}$ & 33 & 22.2 & 20.5 & 5.7 & 8.7 & 32.3 \\
\hline Ir & 33 & 8.7 & 7.4 & 4.1 & 4.1 & 22.3 \\
\hline
\end{tabular}

${ }^{1}$ Standard deviation; ${ }^{2}$ Minimum; ${ }^{3}$ Maximum; ${ }^{4}$ Ratio of the Fe and Mn means, not a mean of the summation of ratios 


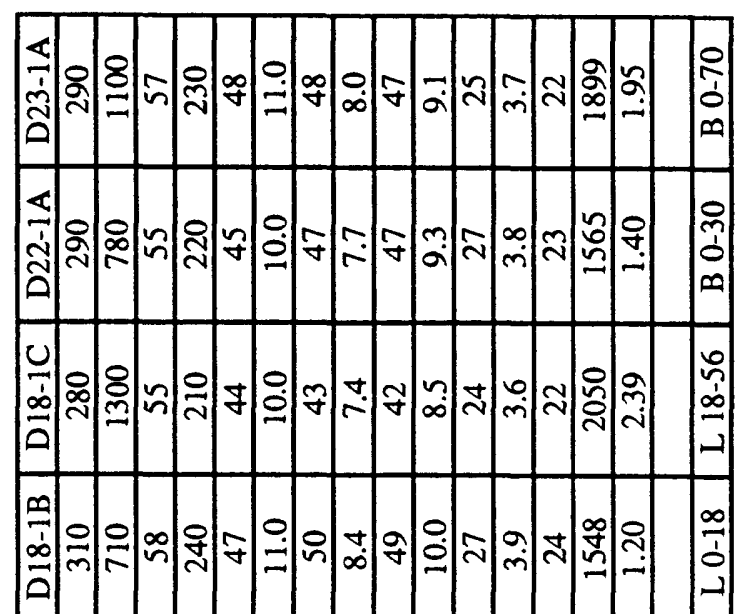

है

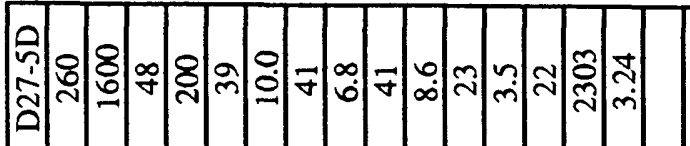
ڤิ)

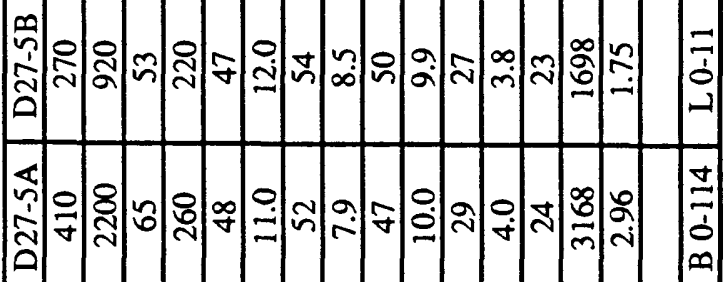

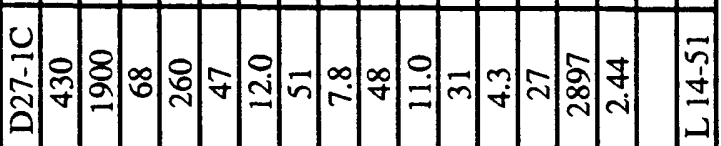

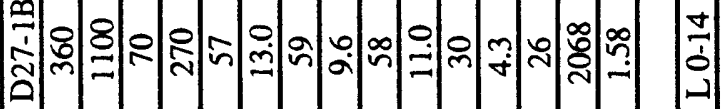

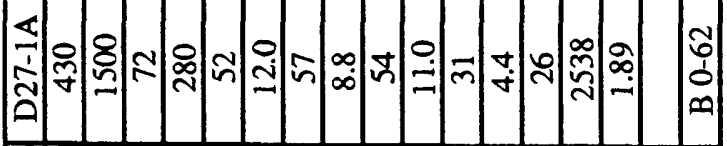
ڤิ) U ฟิ่

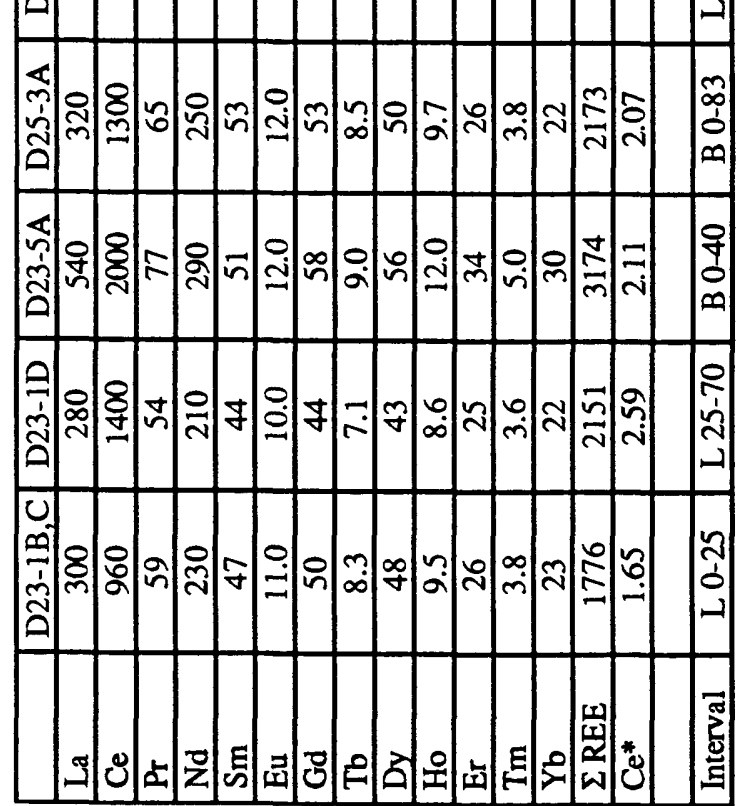


ली

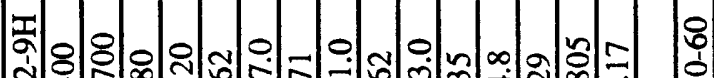

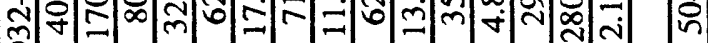

a

ஸि่

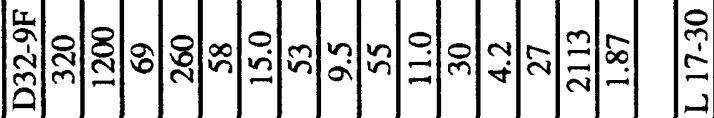

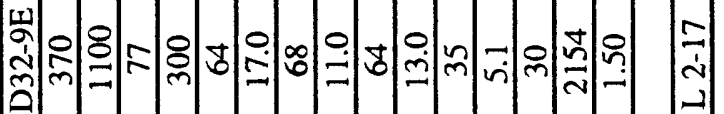

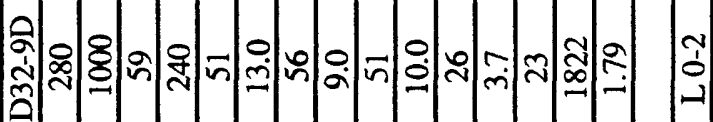

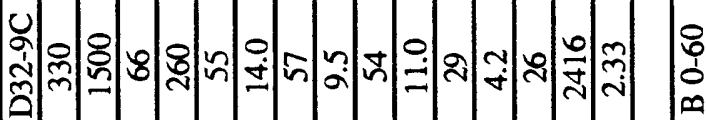

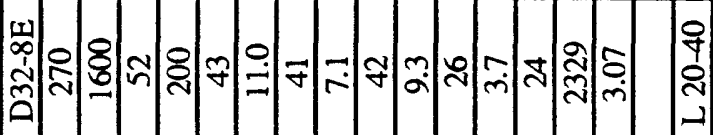

○. 0 o

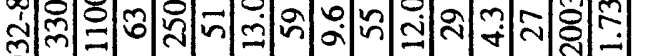

ڤิ

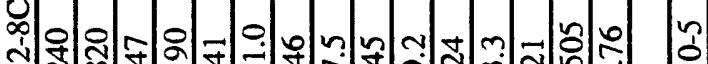

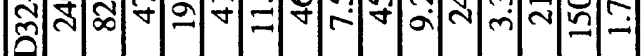

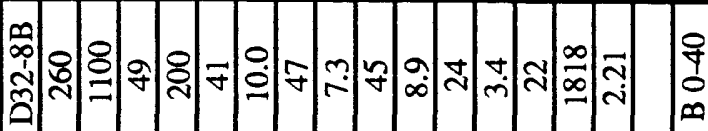

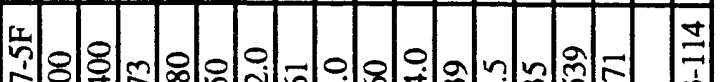

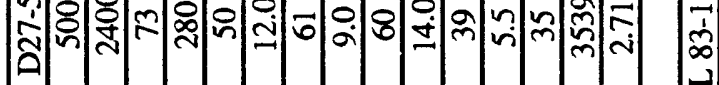

苞

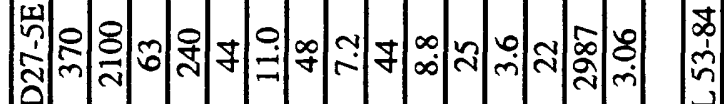

ถิ

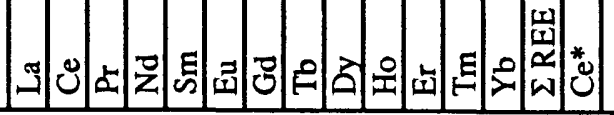

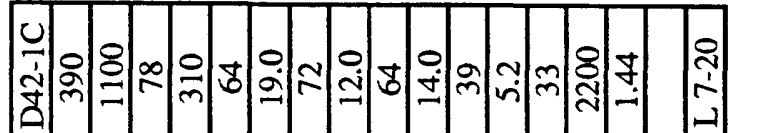

ปิ

饪

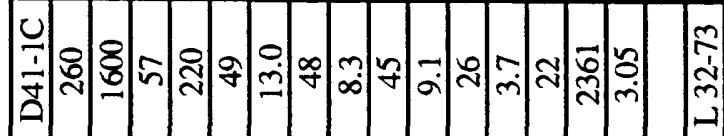

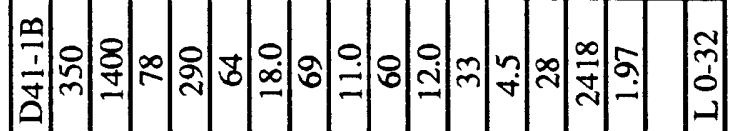

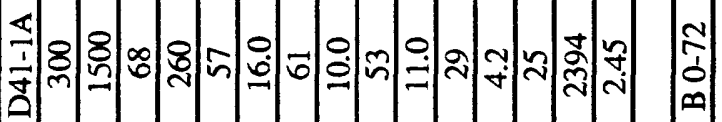

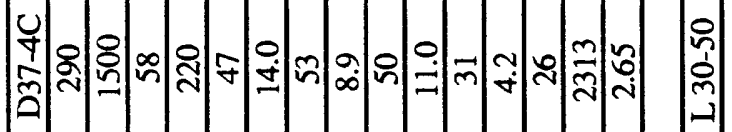

商金局

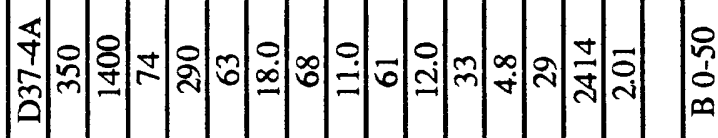

लि० O O

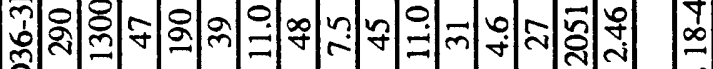

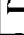

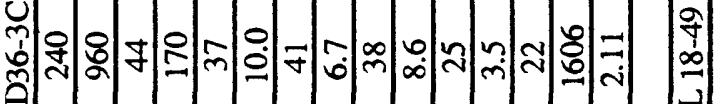

ஸิ

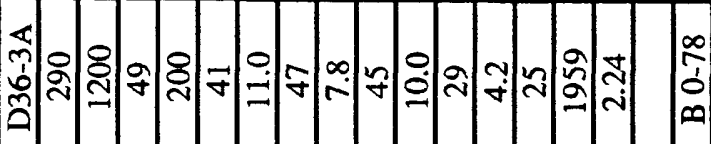

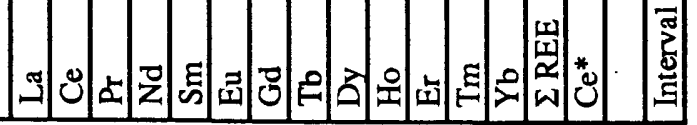

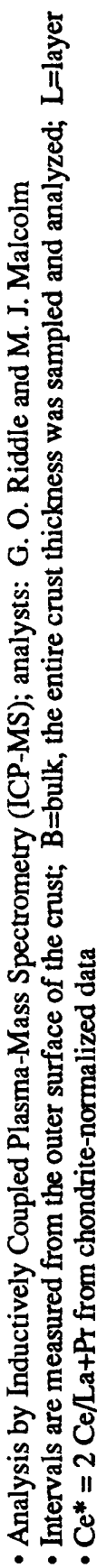




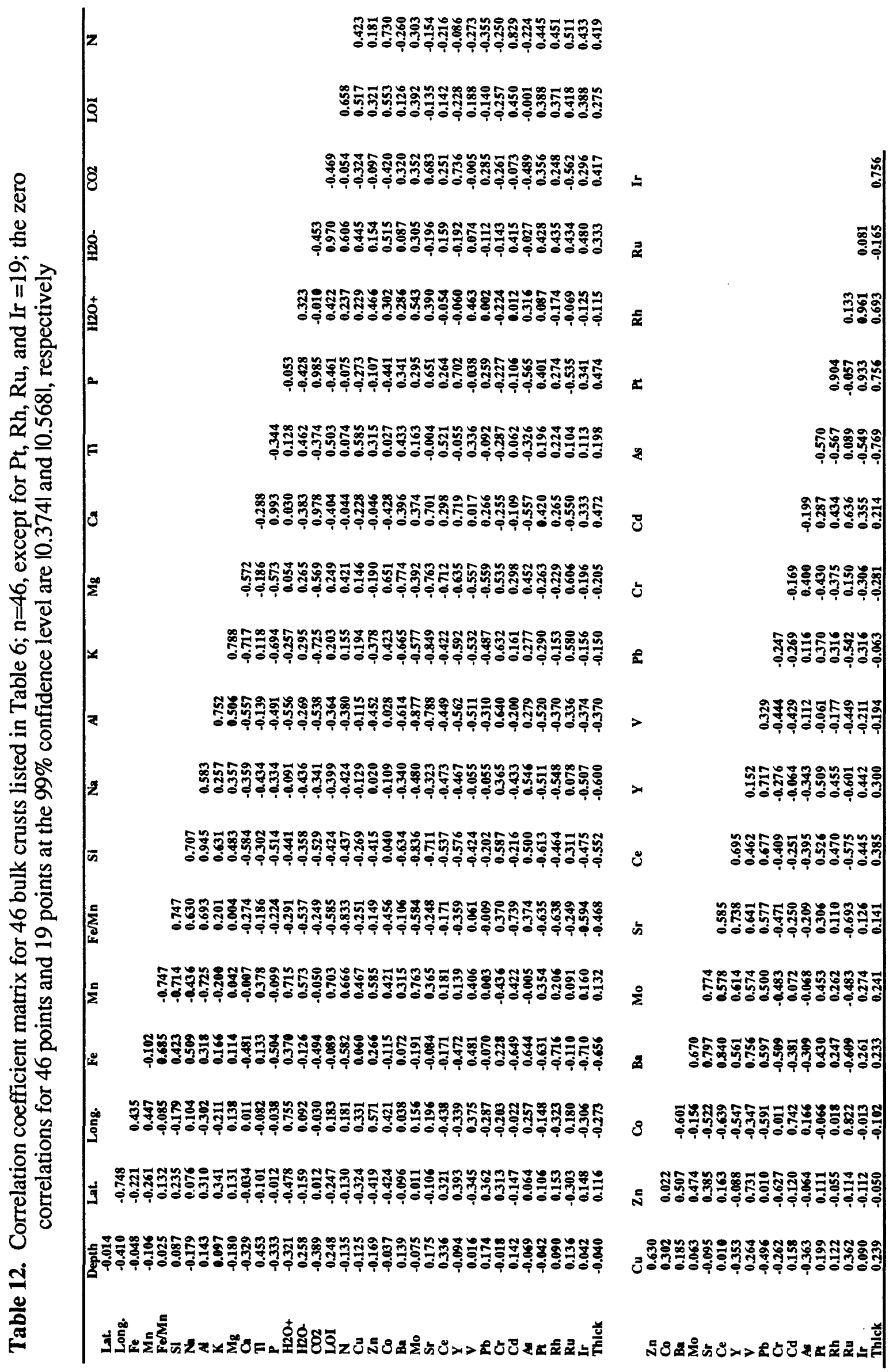




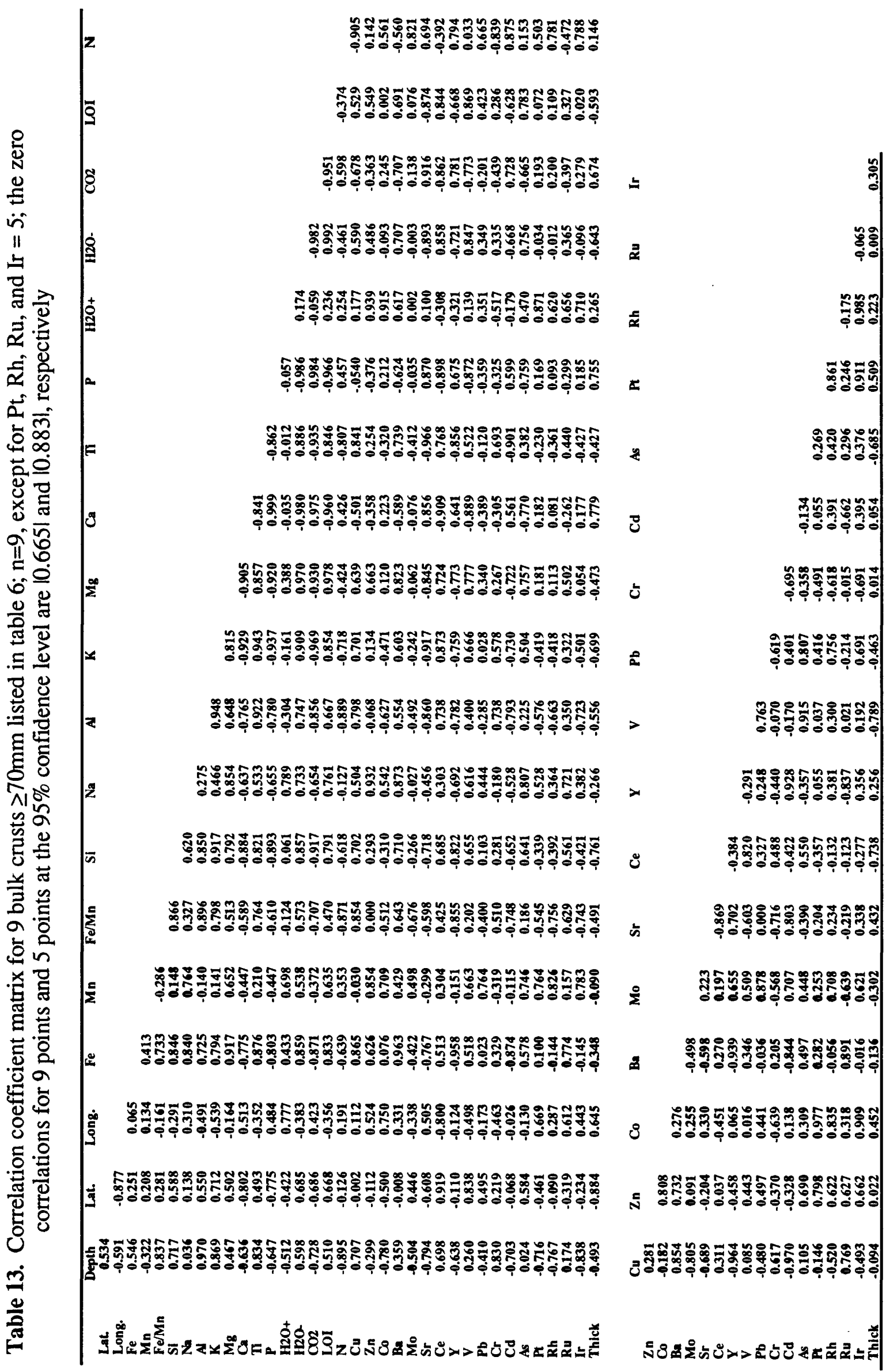




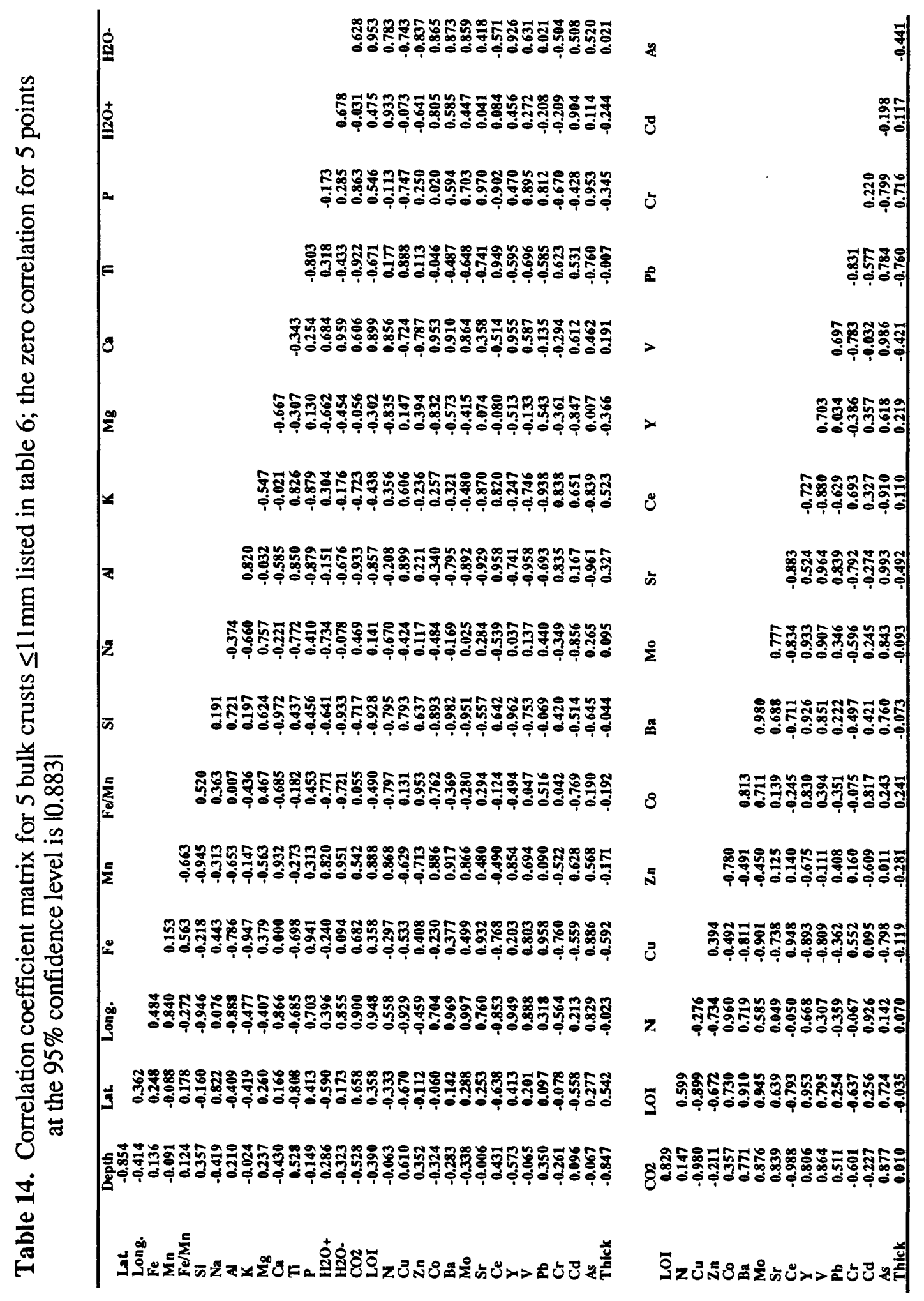




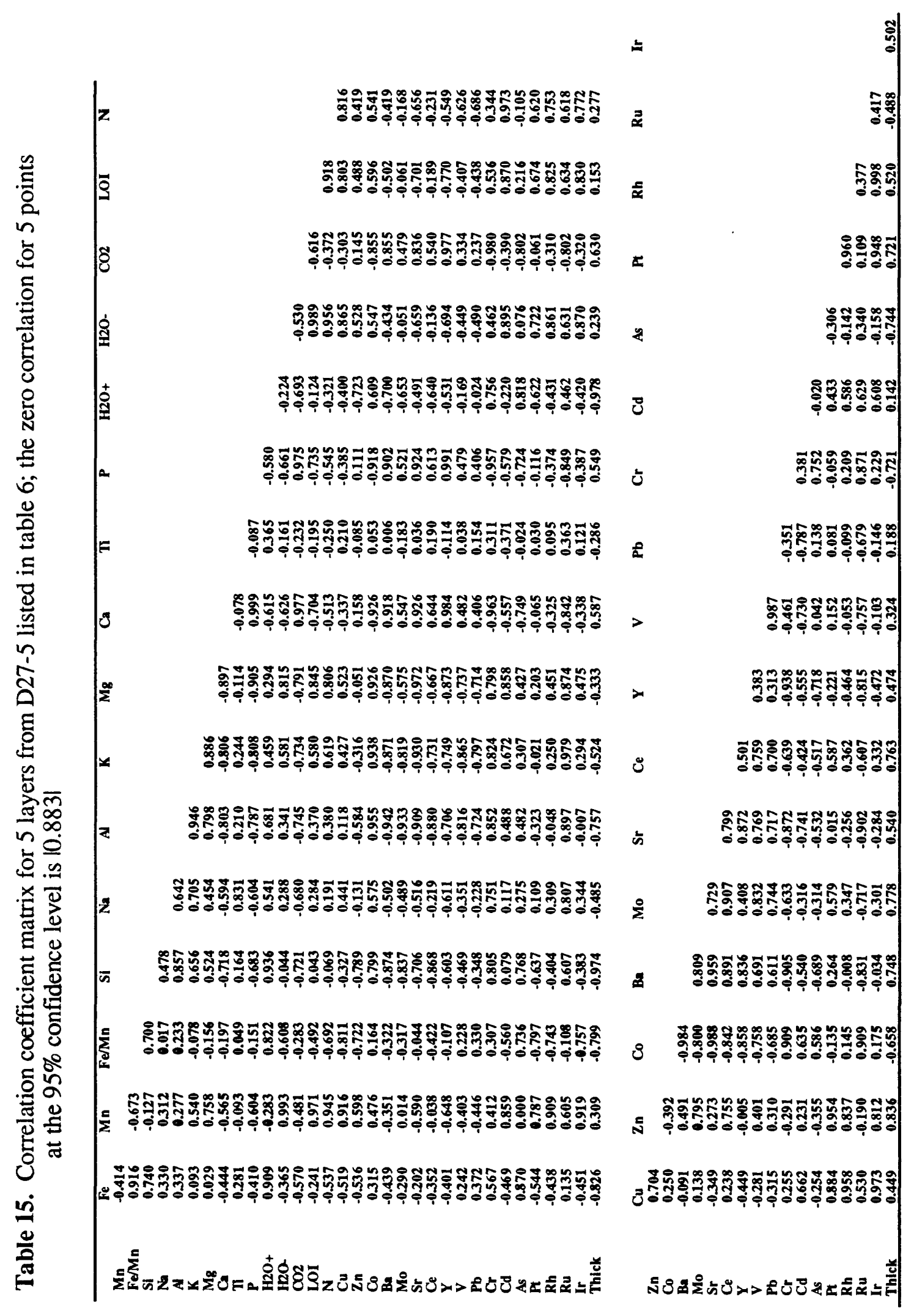




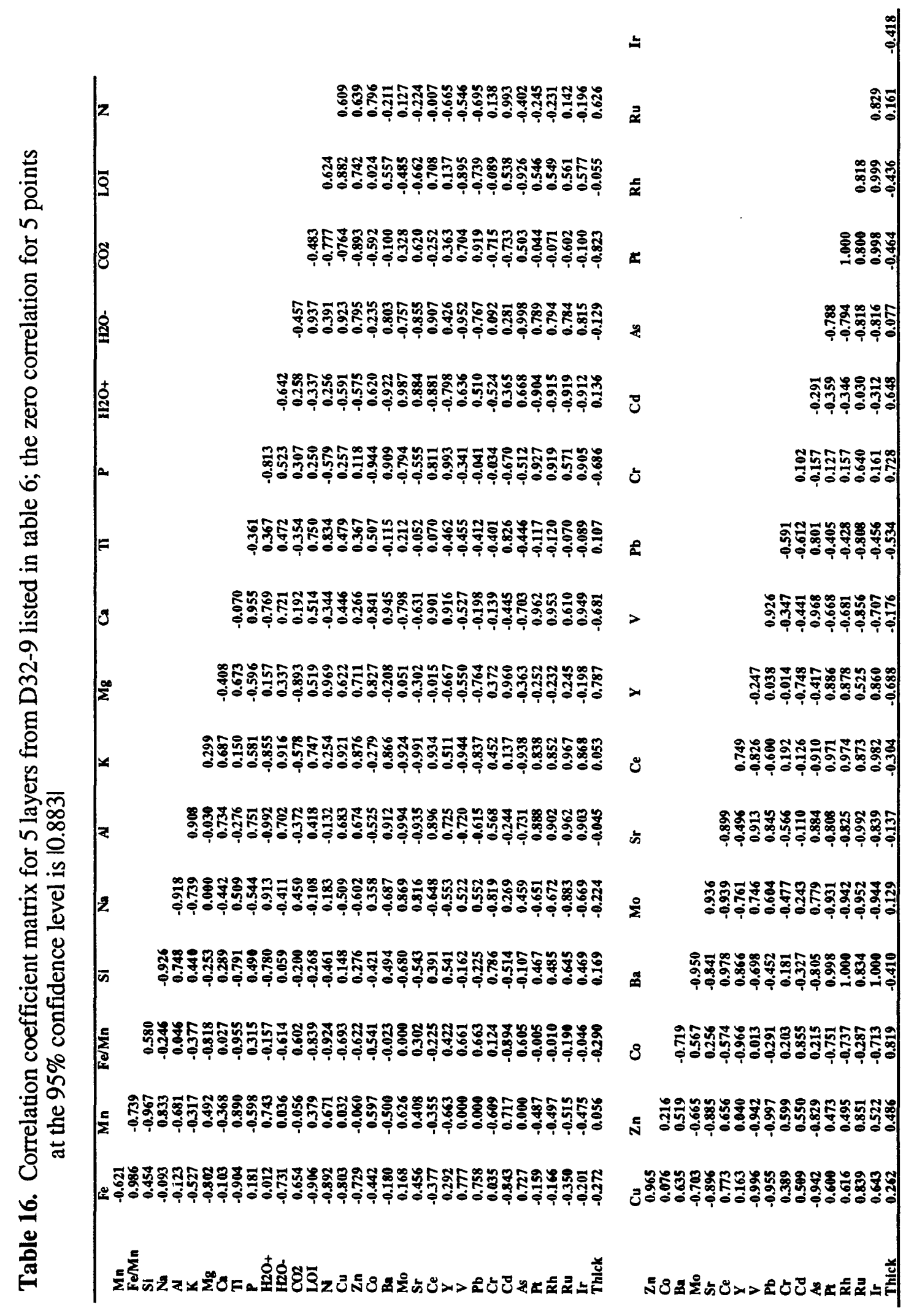




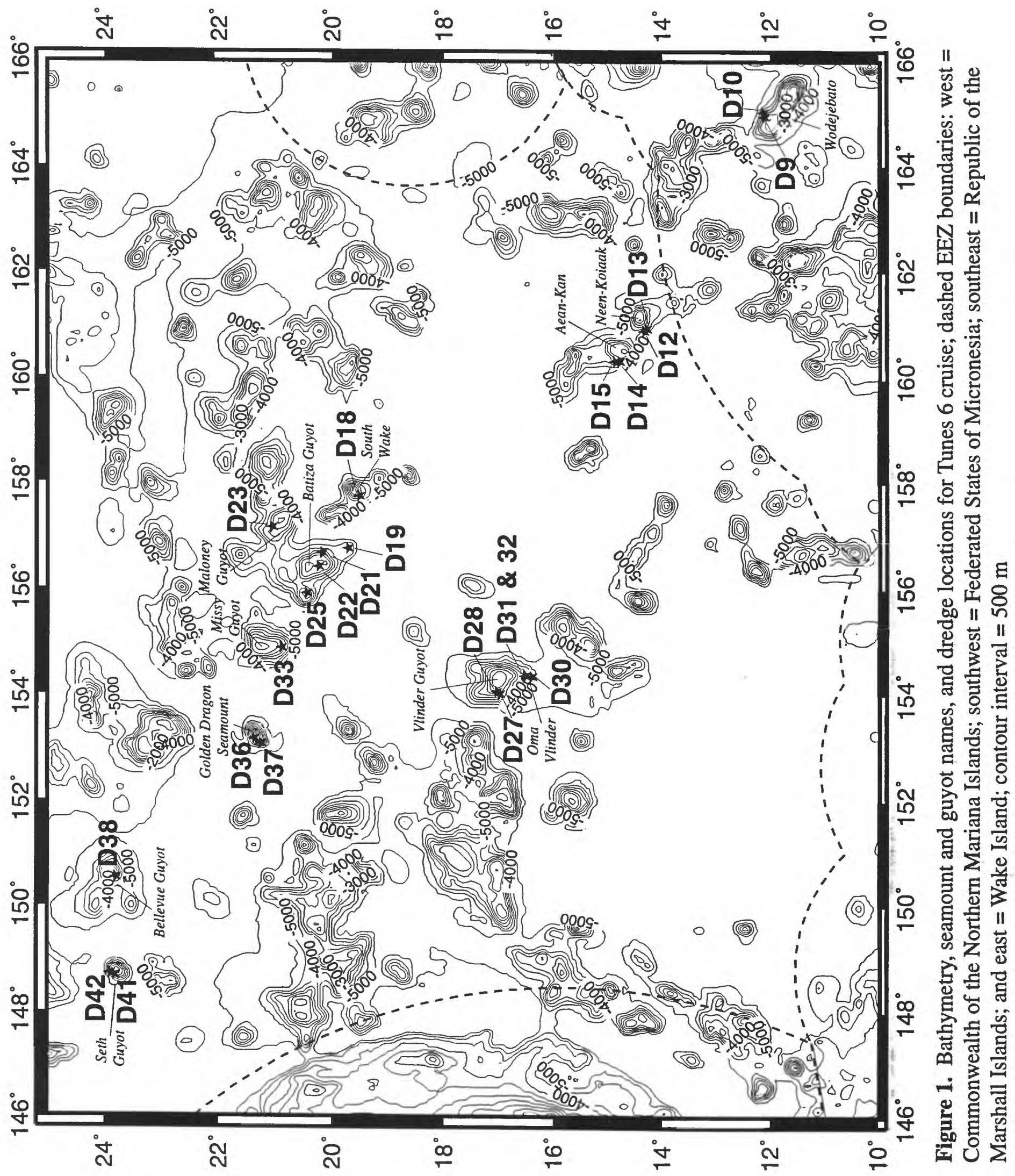



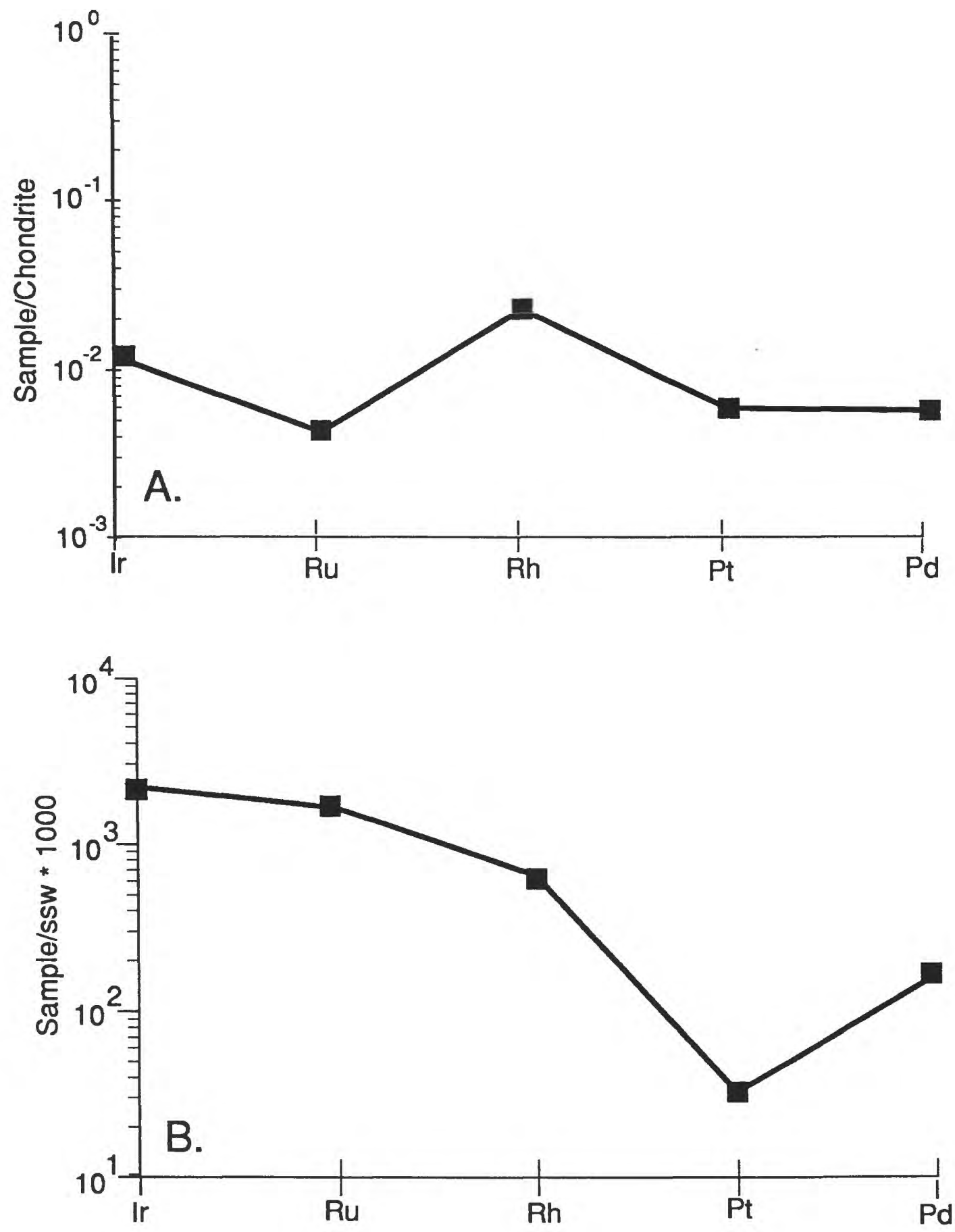

Figure 2. Mean PGE concentrations in 46 bulk crusts (A) normalized to chondrites (Anders and Grevesse, 1989) and (B) to surface seawater abundance (Goldberg, 1987; Bertine et al., 1993); Pd contents of the Fe-Mn crusts are less than the limit of detection, therefore the Pd points are maximum ratios 

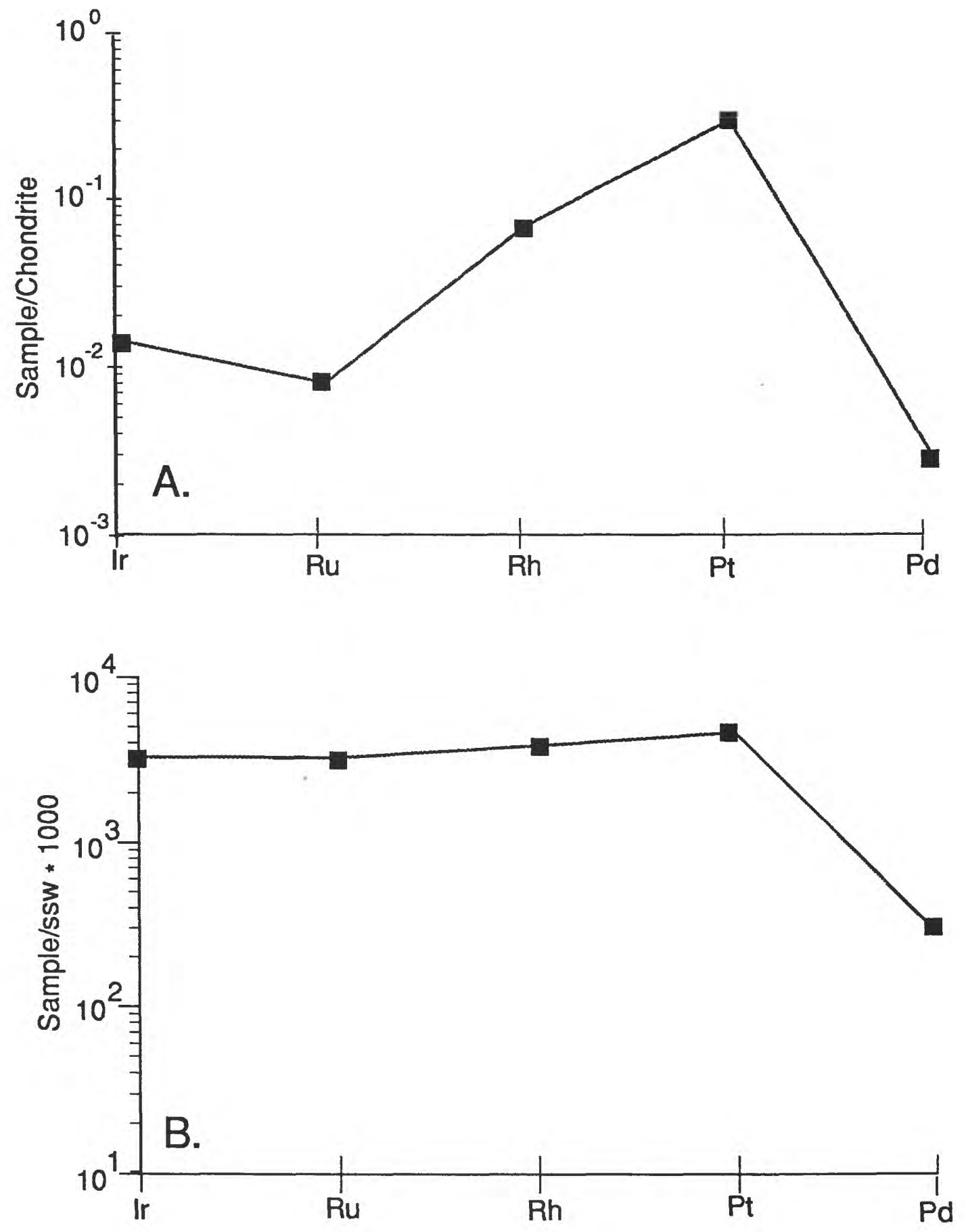

Figure 3. Mean PGE concentrations in D32-9H, 50-60 mm (A) normalized to chondrites (Anders and Grevesse, 1989) and (B) to surface seawater abundance (Goldberg,1987; Bertine et al., 1993); Pd contents of the $\mathrm{Fe}-\mathrm{Mn}$ crusts are less than the limit of detection, therefore the Pd points are maximum ratios. 

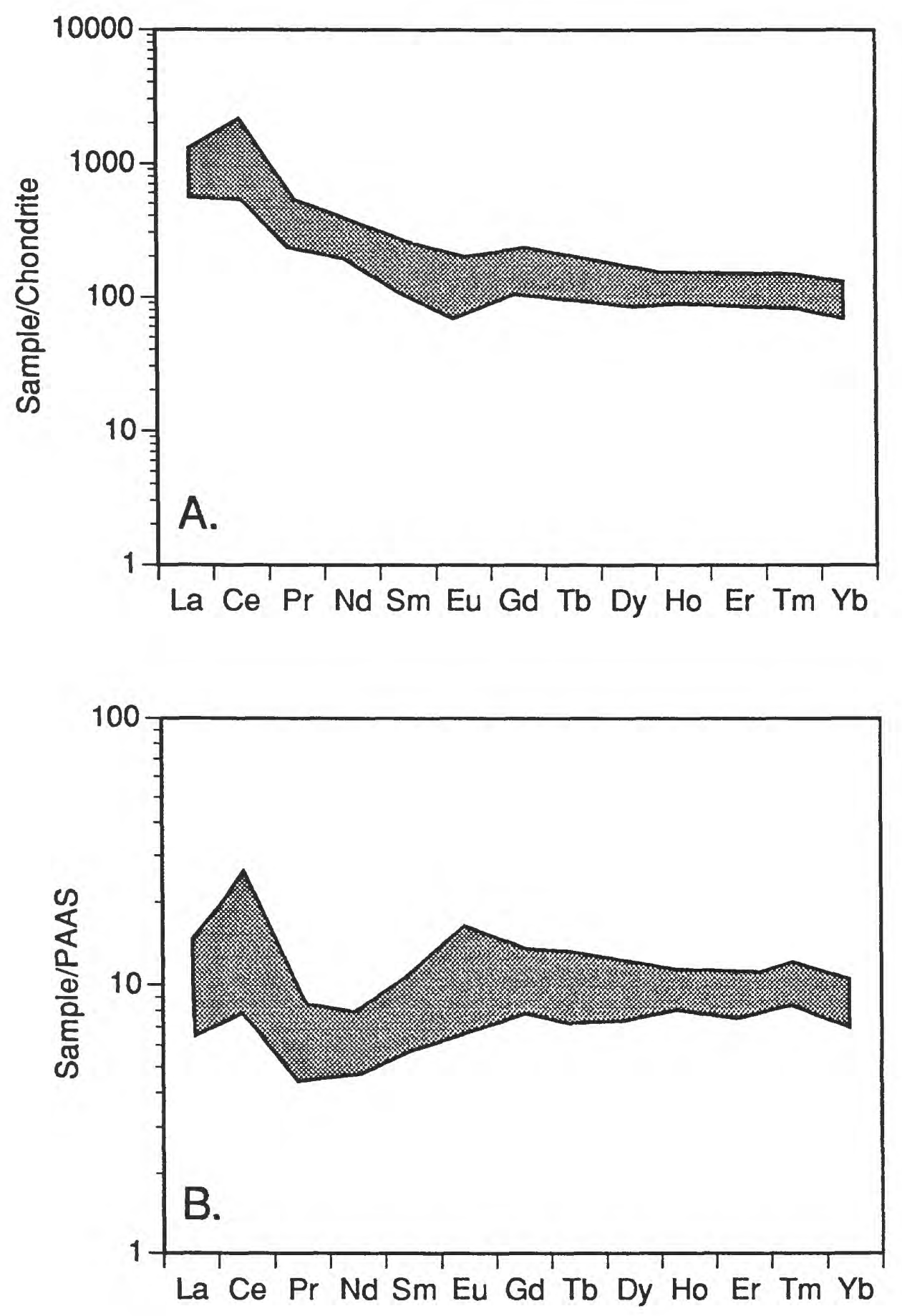

Figure 4. REE range plots for all $52 \mathrm{Fe}-\mathrm{Mn}$ crust samples: (A)

Chondrite normalized, and (B) PAAS normalized 

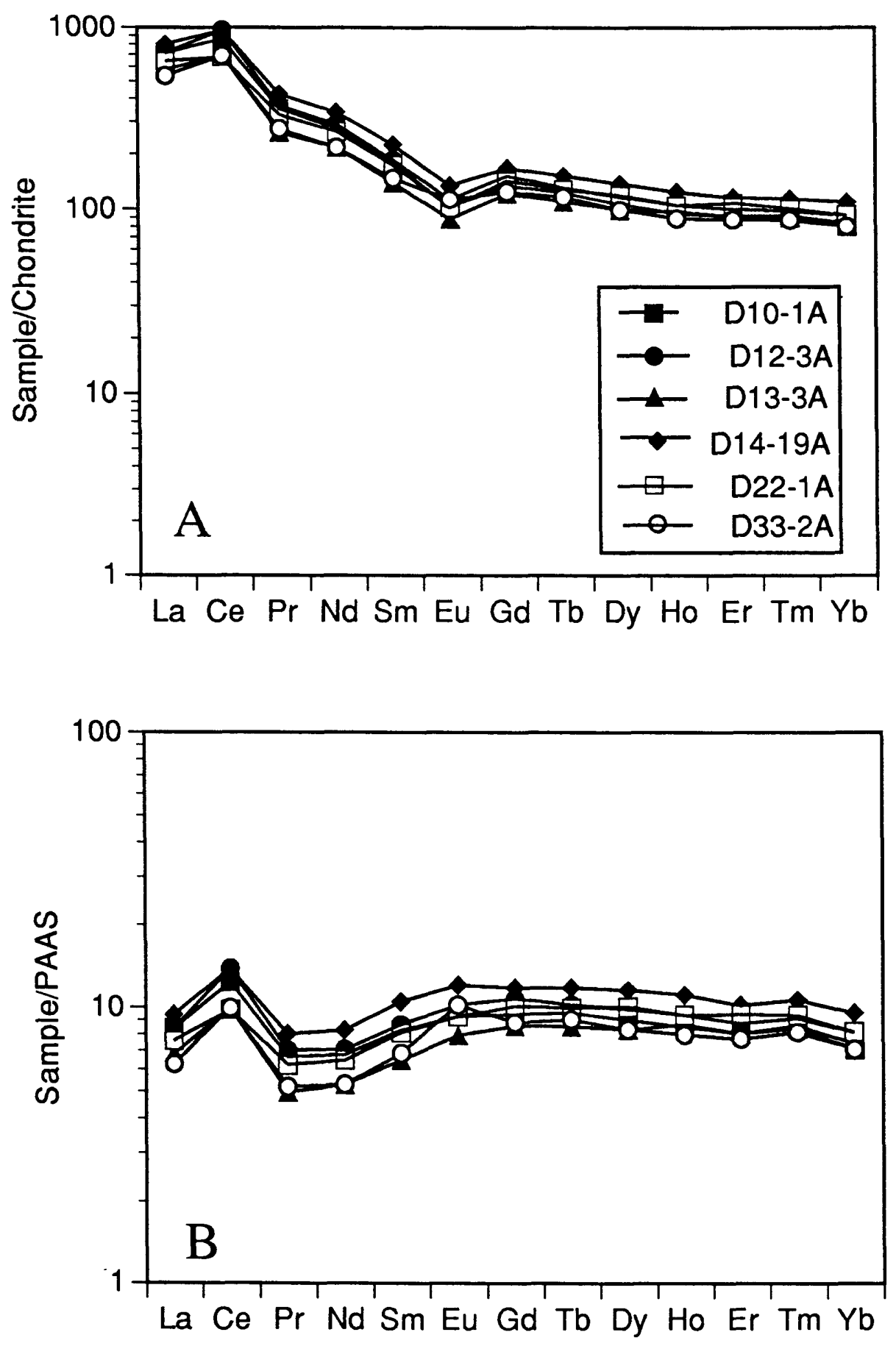

Figure 5. REE plots of bulk crusts from Wodejebato, Neen-Kiaakk, Batiza, Missy, and Aean-Kan Guyots: (A) Chondrite normalized, and (B) PAAS normalized 

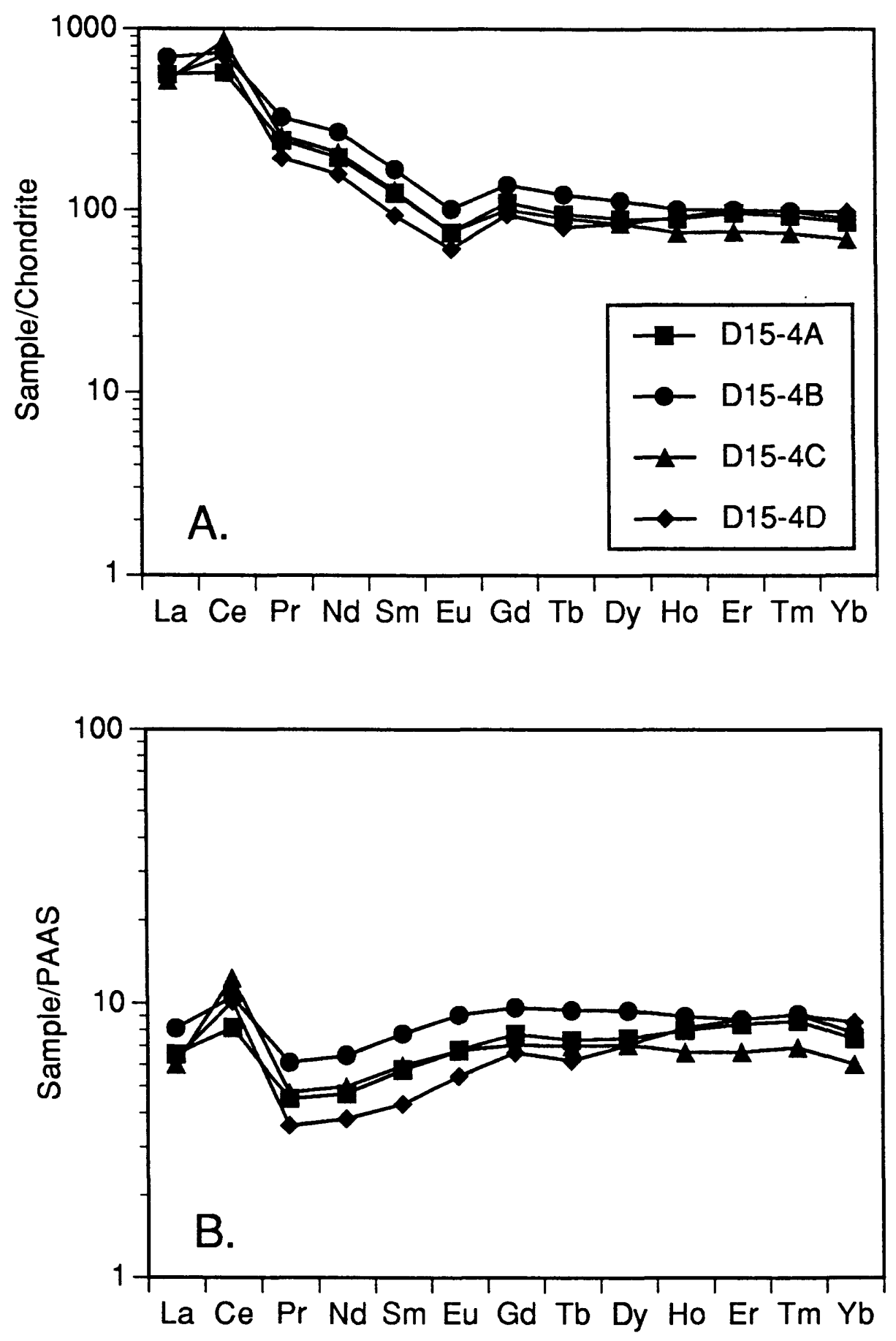

Figure 6. REE plots of crust samples from D15-4, Aean-Kan Guyot: (A) chondrite normalized, and (B) PAAS normalized 

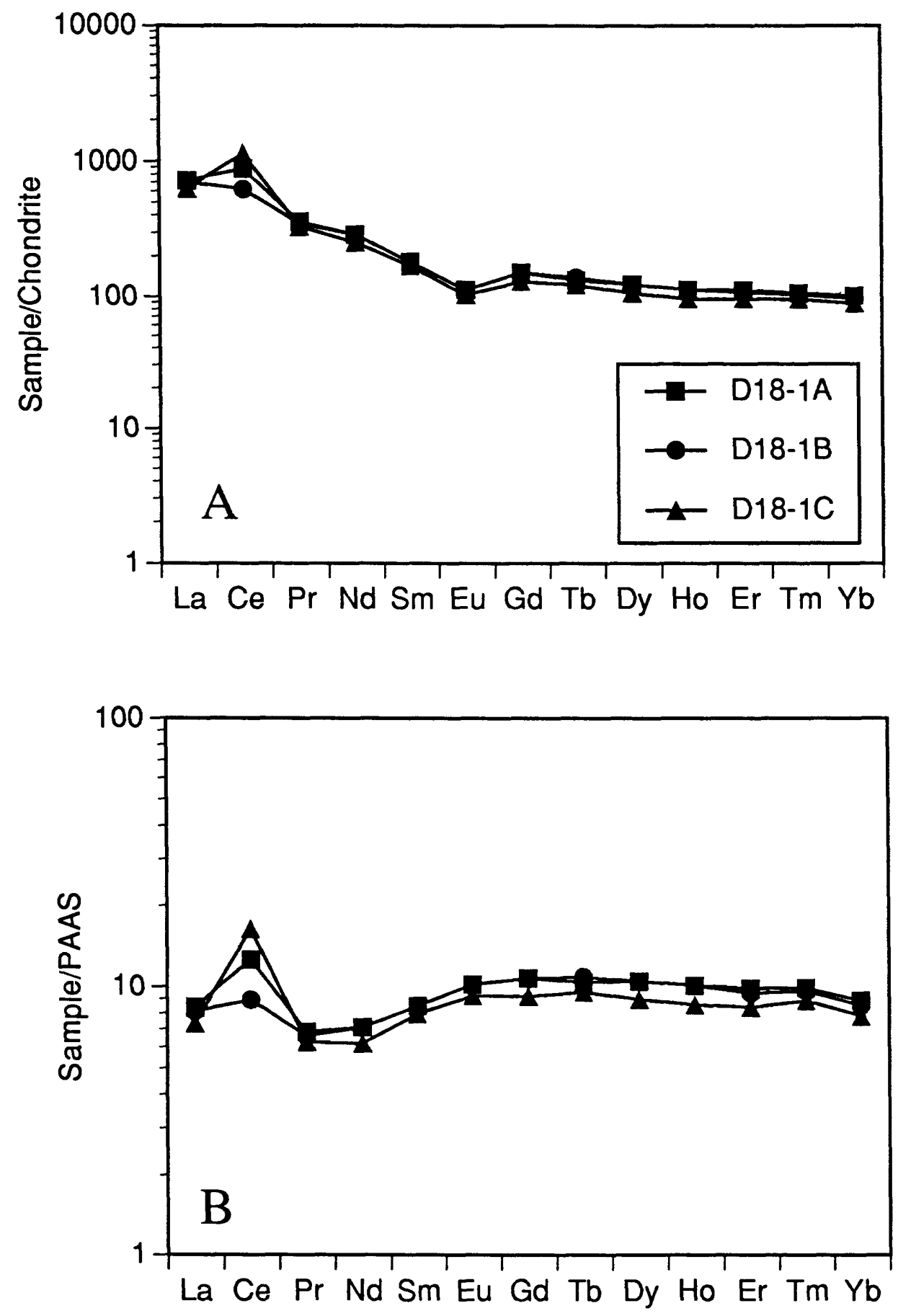

Figure 7. REE plots of crust samples from D18-1, South Wake Guyot: (A) Chondrite normalized, and (B) PAAS normalized 

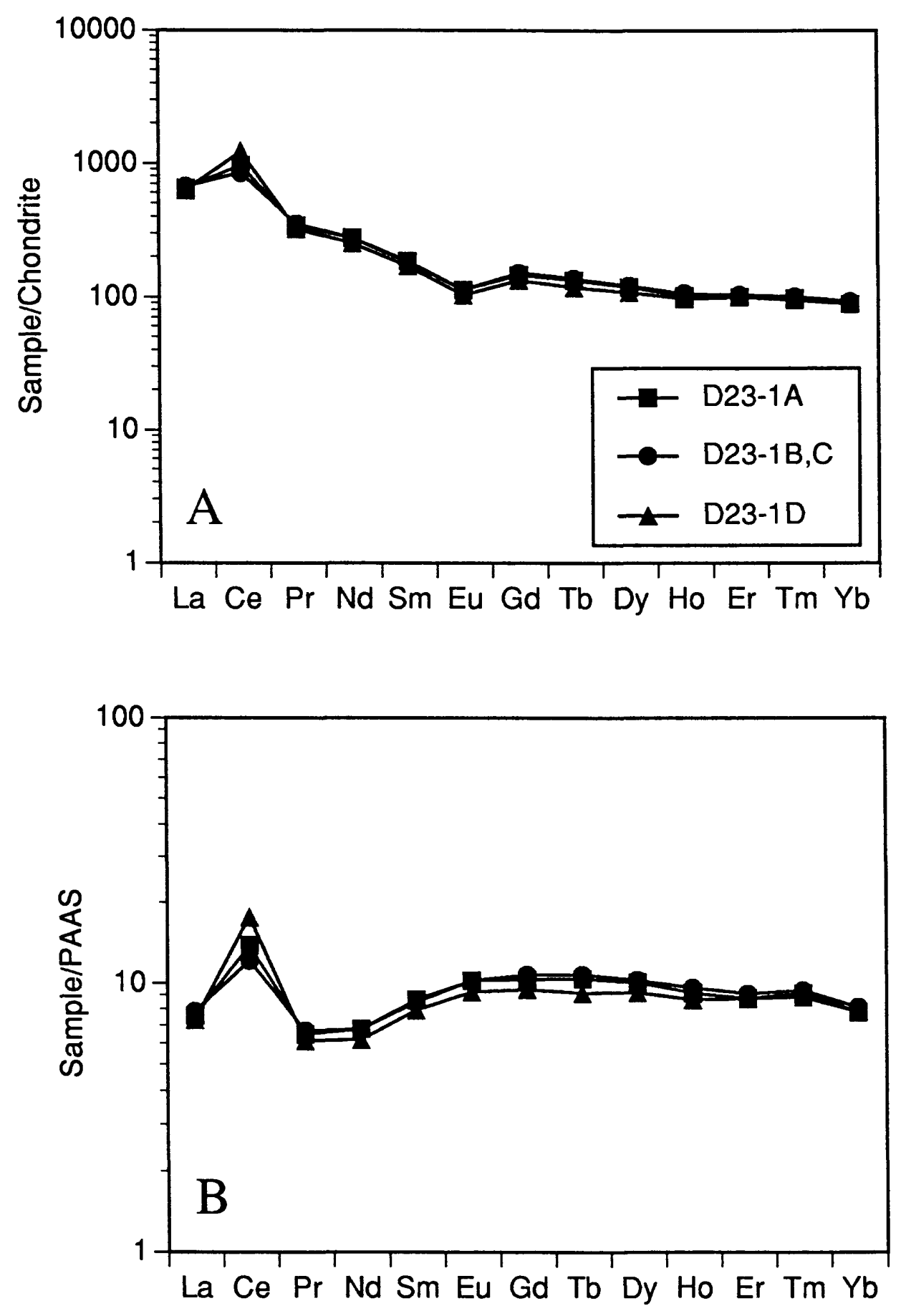

Figure 8. REE plots of crust samples from D23-1, Maloney Guyot: (A) Chondrite normalized, and (B) PAAS normalized 

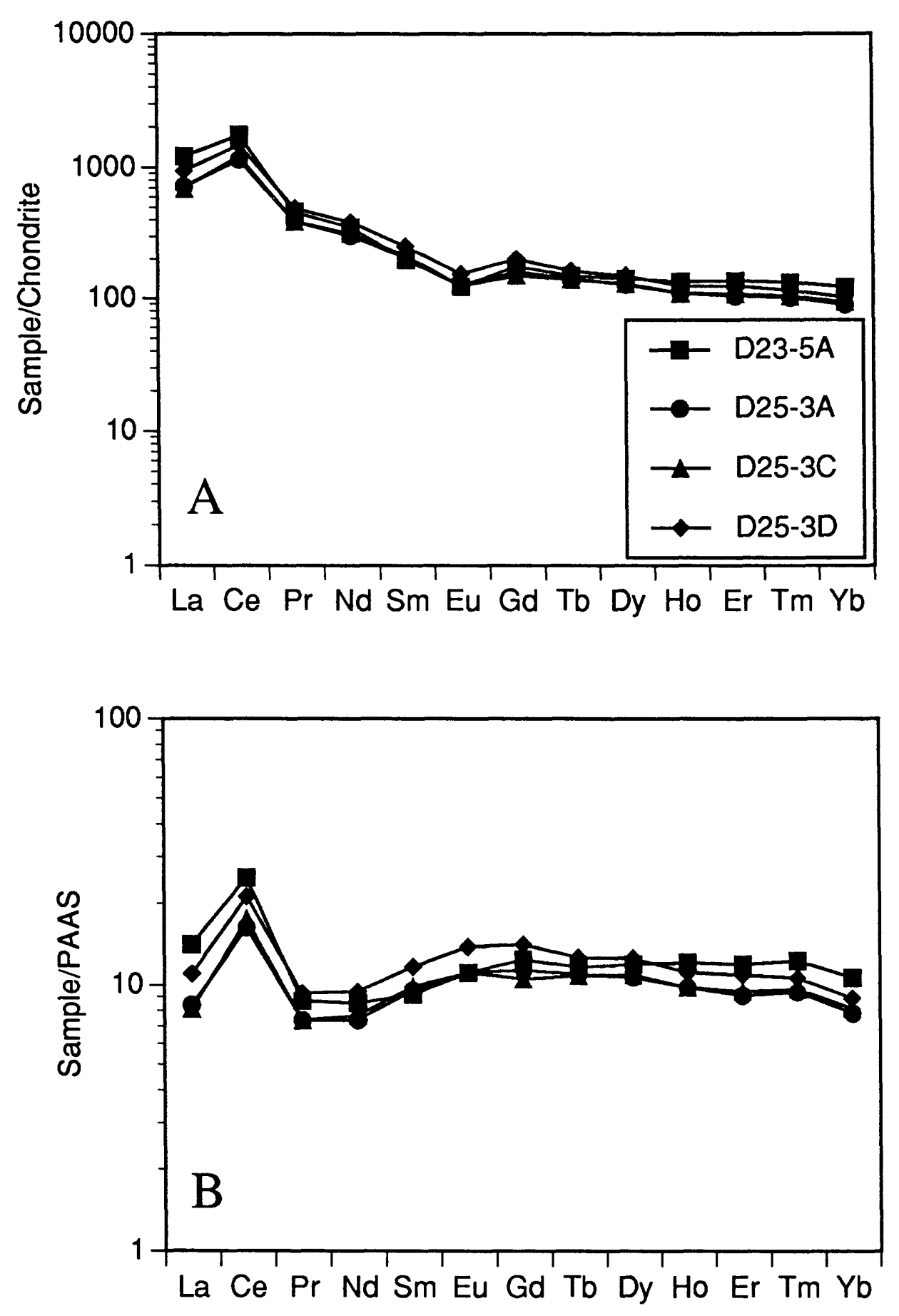

Figure 9. REE plots of crust samples from D25-3, West Batiza Guyot: (A) Chondrite normalized, and (B) PAAS normalized 

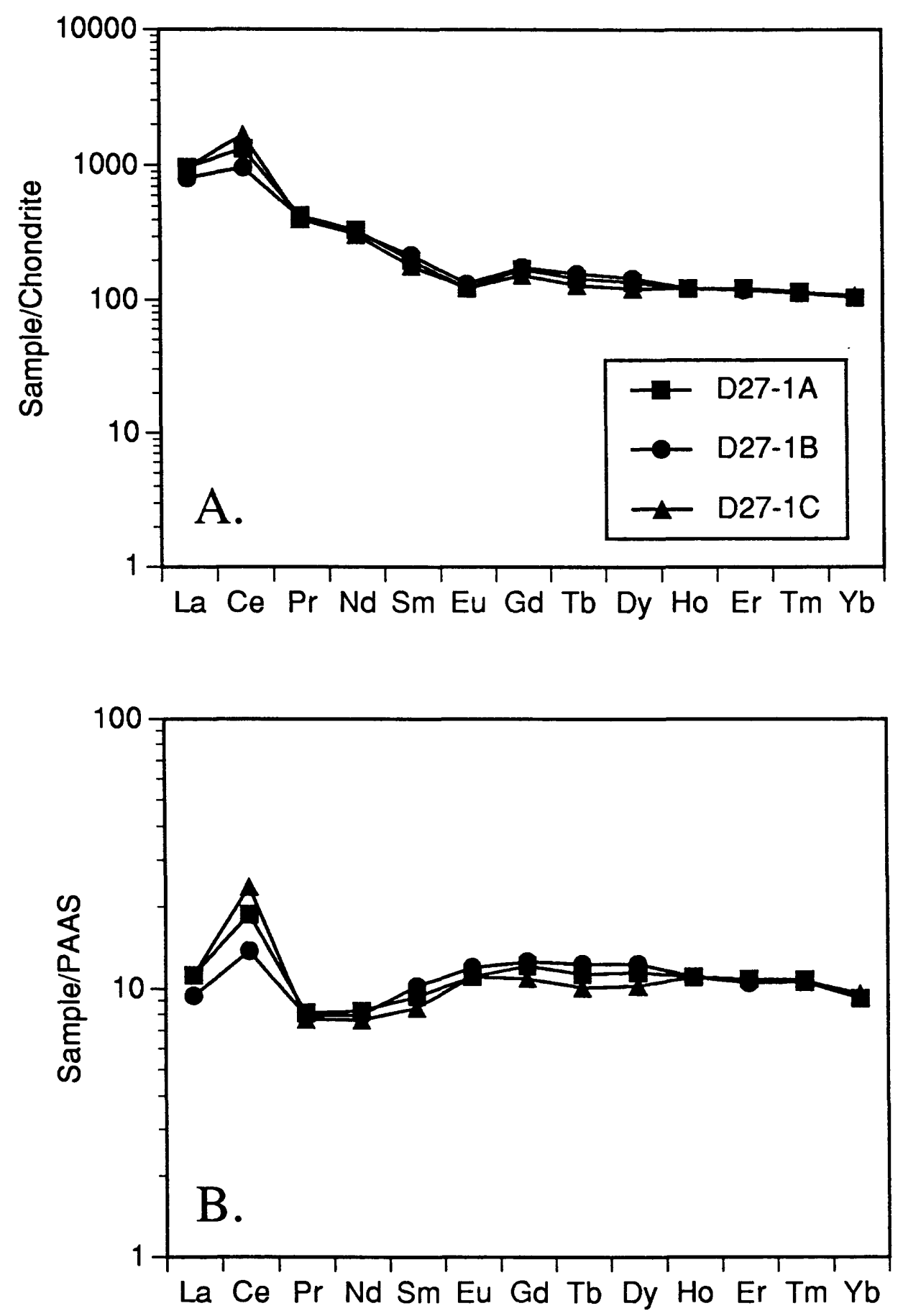

Figure 10. REE plots of crust samples from D27-1, Vlinder Guyot: (A) chondrite normalized, and (B) PAAS normalized 

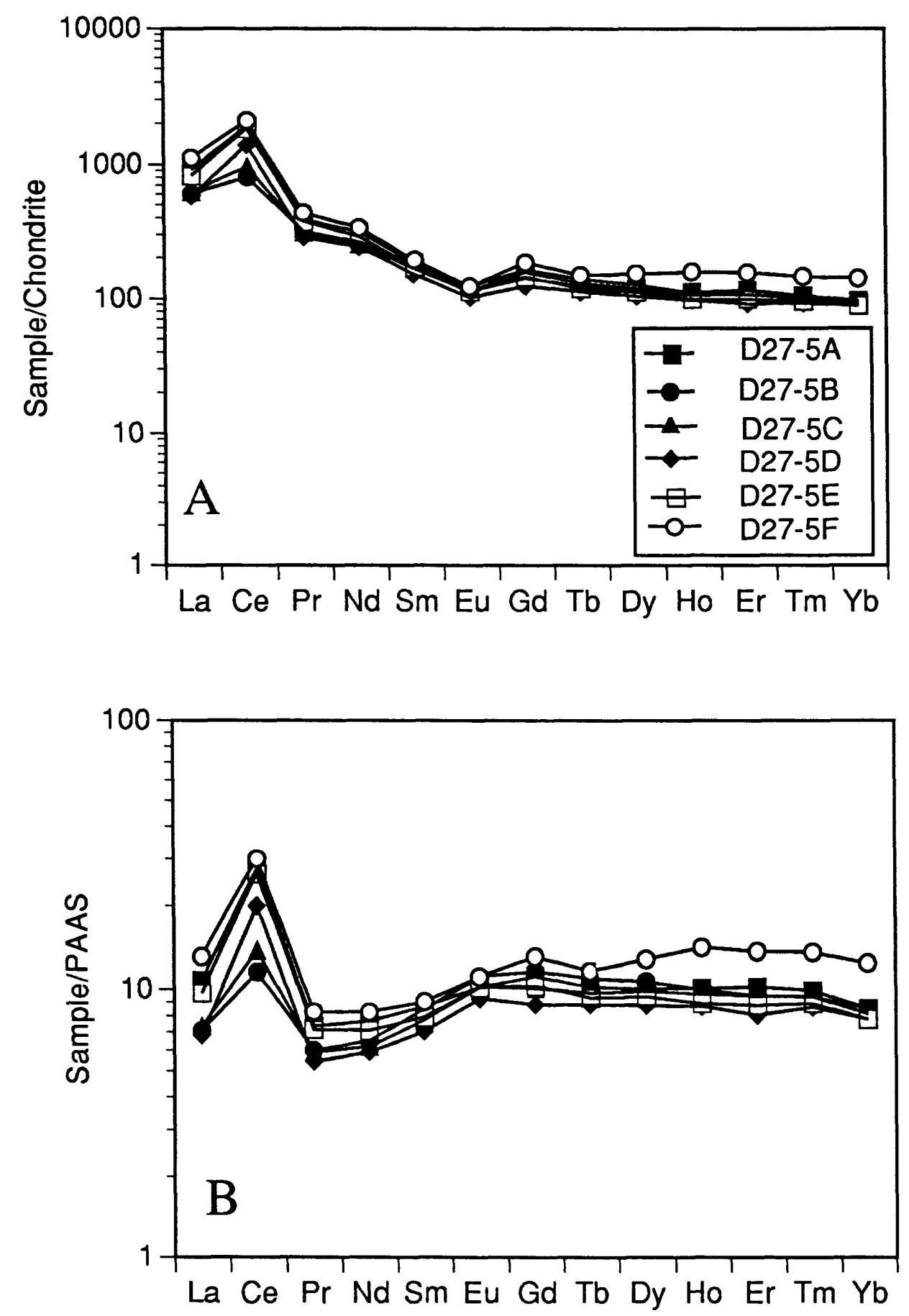

Figure 11. REE plots of crust samples from D27-5, Vlinder Guyot: (A) Chondrite normalized, and (B) PAAS normalized 

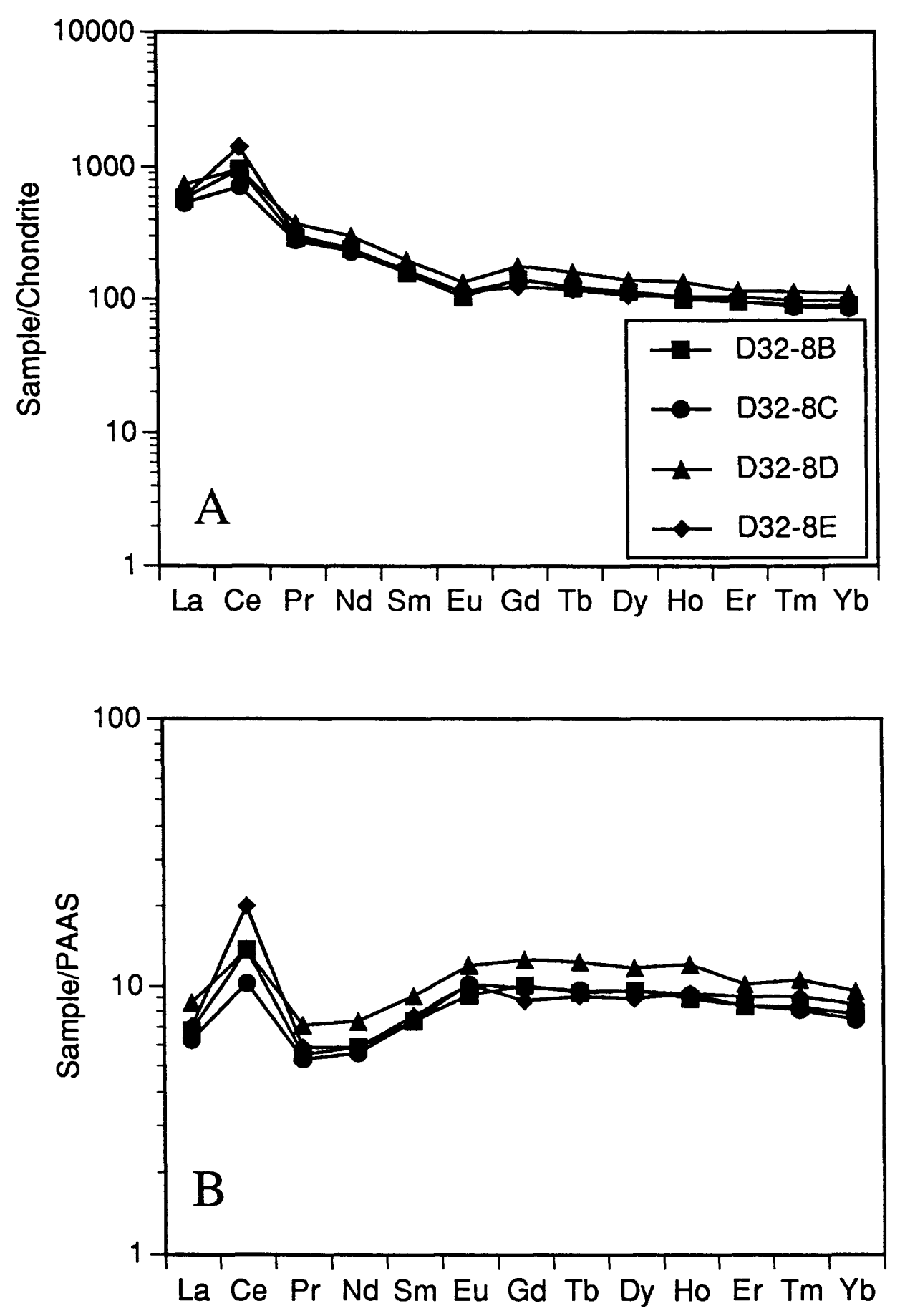

Figure 12. REE plots of crust samples from D32-8, Oma Vlinder Guyot: (A) Chondrite normalized, and (B) PAAS normalized 

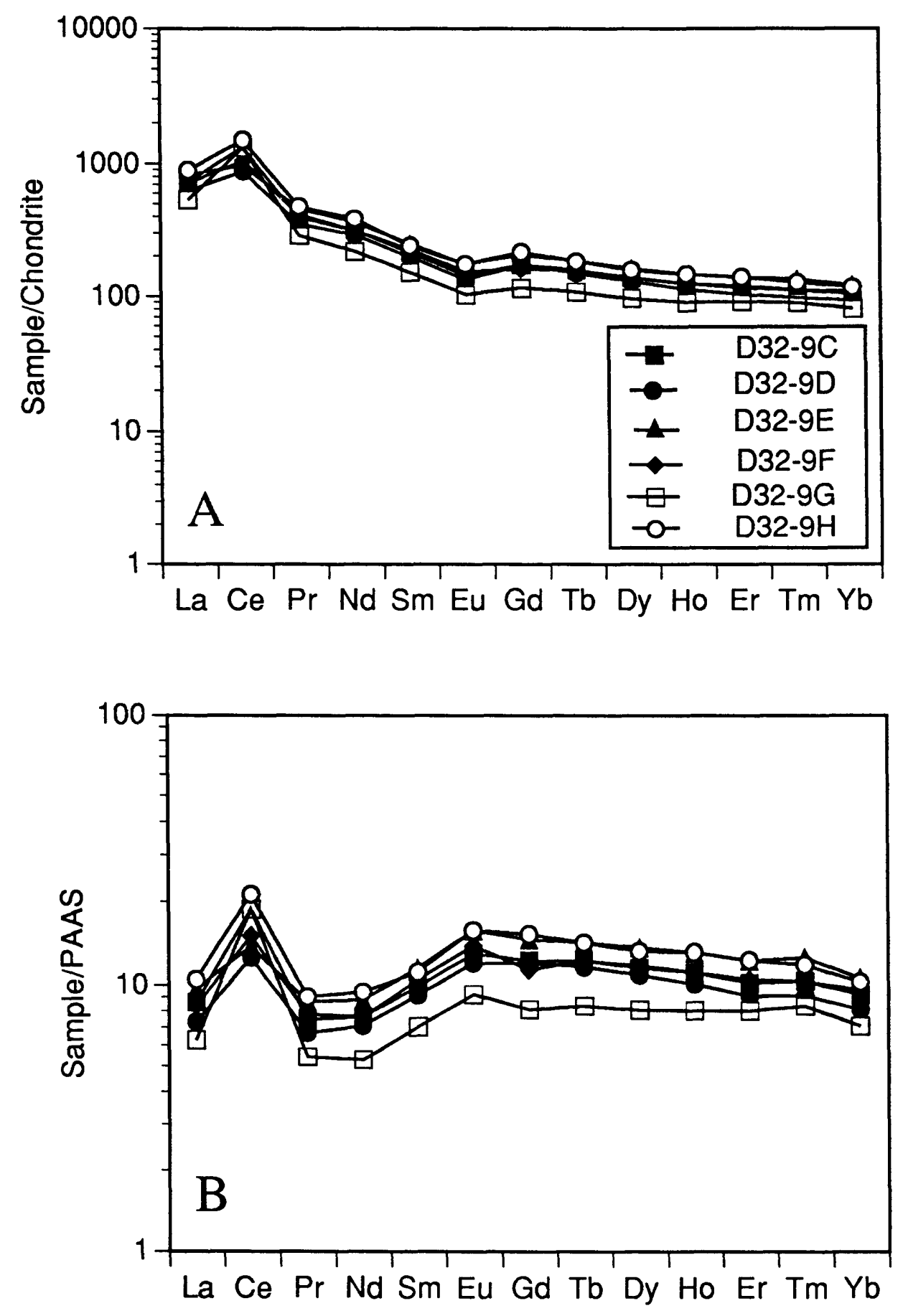

Figure 13. REE plots of crust samples from D32-9, Oma Vlinder Guyot: (A) Chondrite normalized, and (B) PAAS normalized 

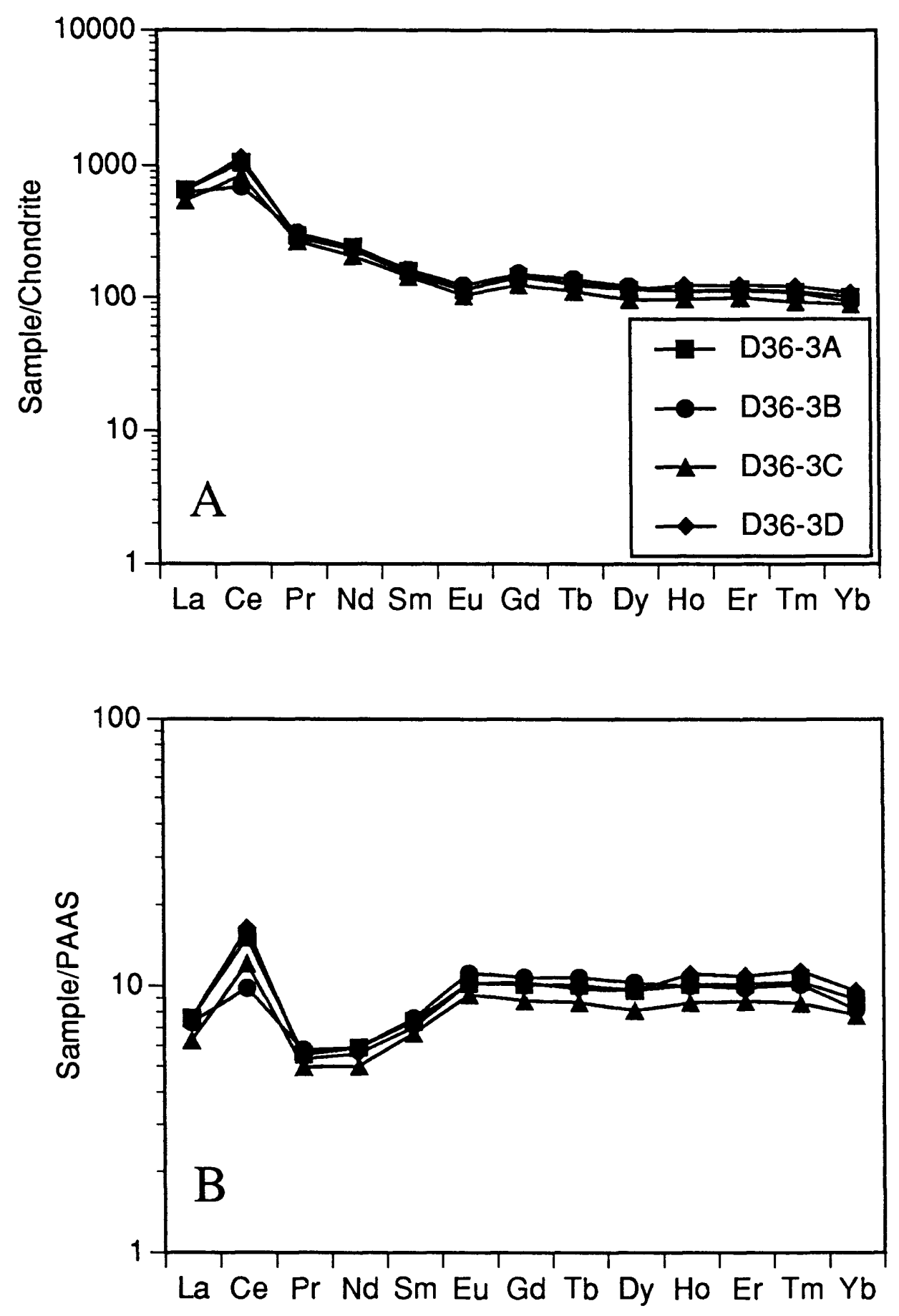

Figure 14. REE plots of crust samples from D36-3, Golden Dragon Seamount: (A) Chondrite normalized, and (B) PAAS normalized 

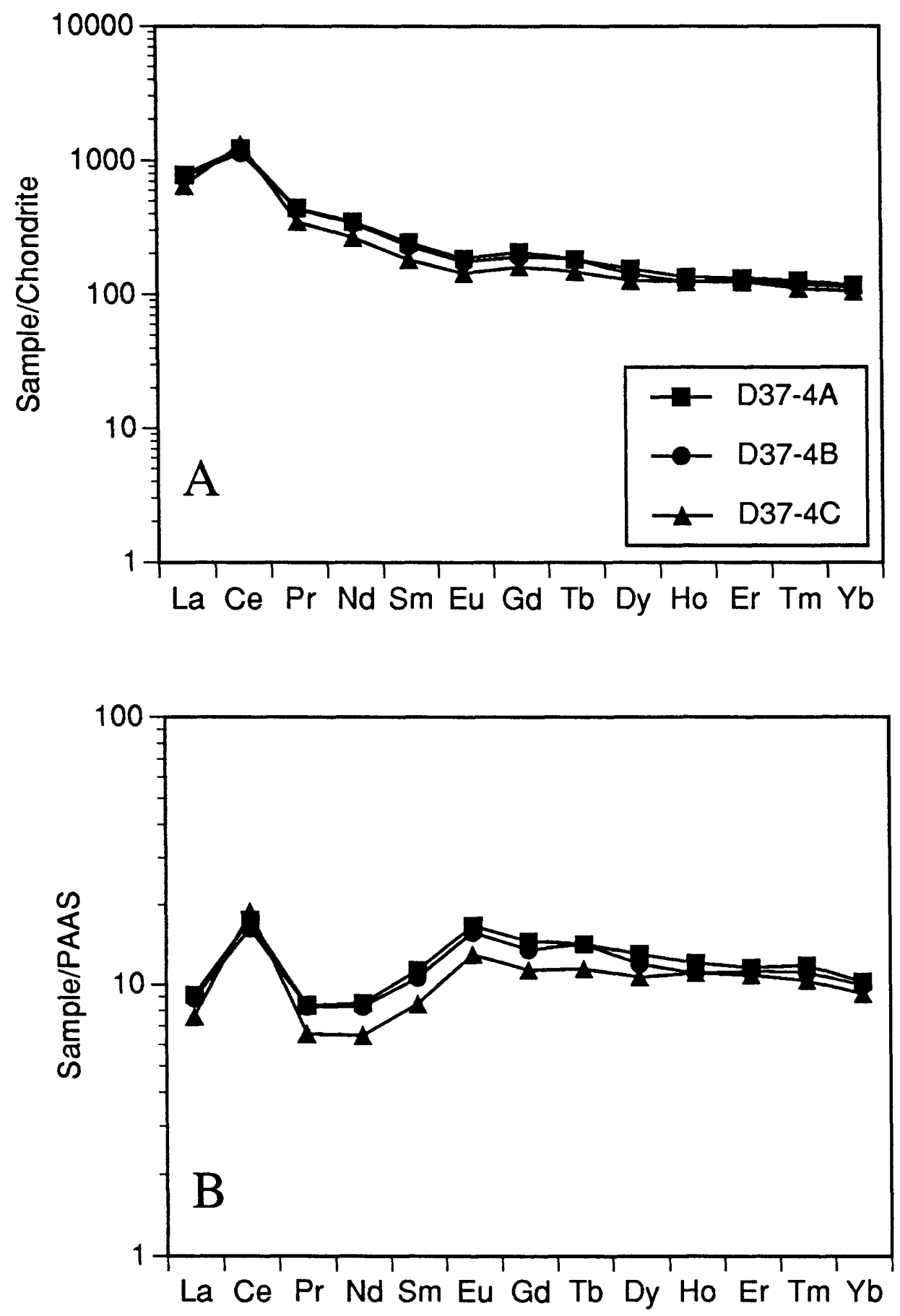

Figure 15. REE plots of crust samples from D37-4, Golden Dragon Seamount: (A) Chondrite normalized, and (B) PAAS normalized 

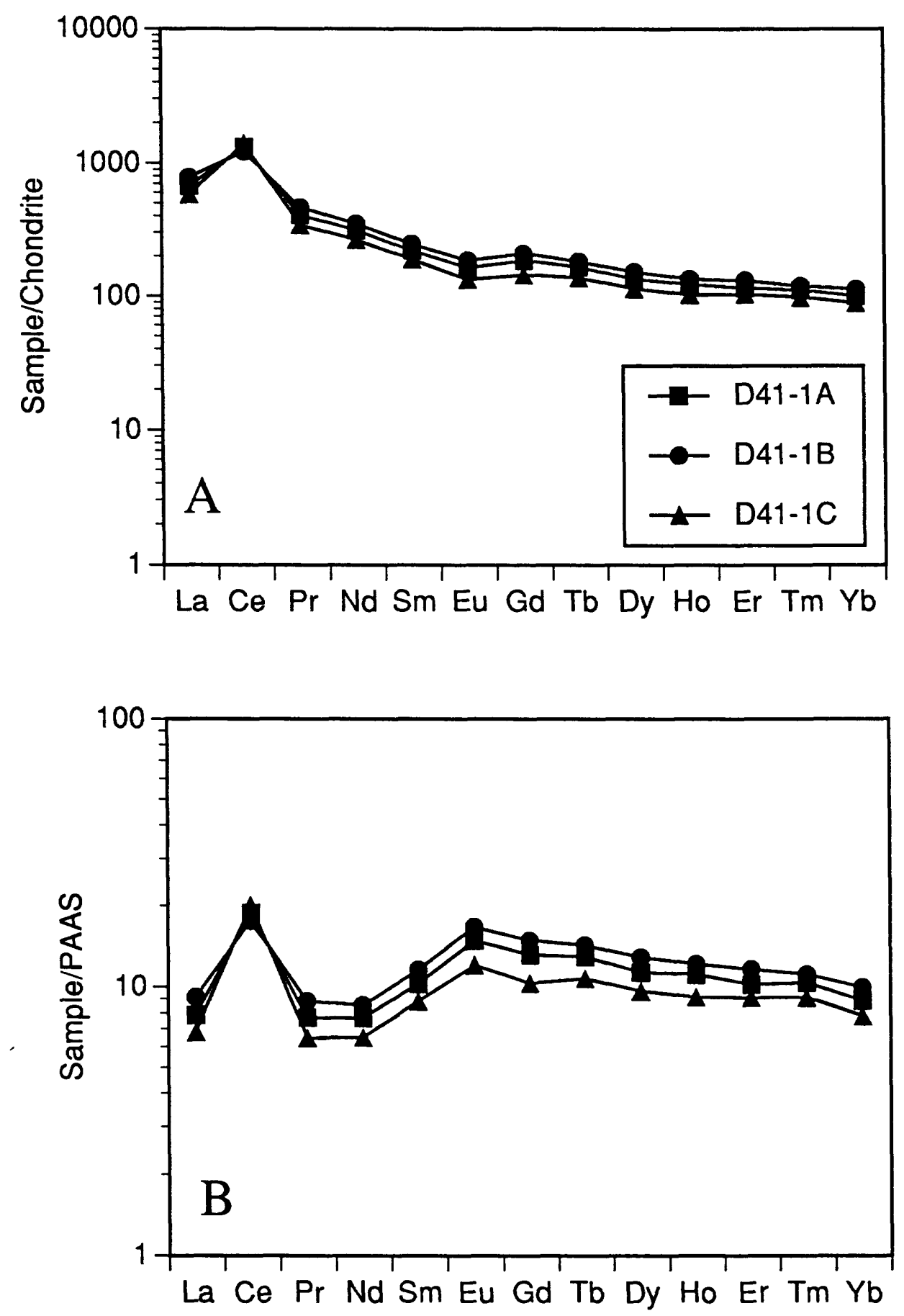

Figure 16. REE plots of crust samples from D41-1, Seth Guyot: (A) Chondrite normalized, and (B) PAAS normalized 

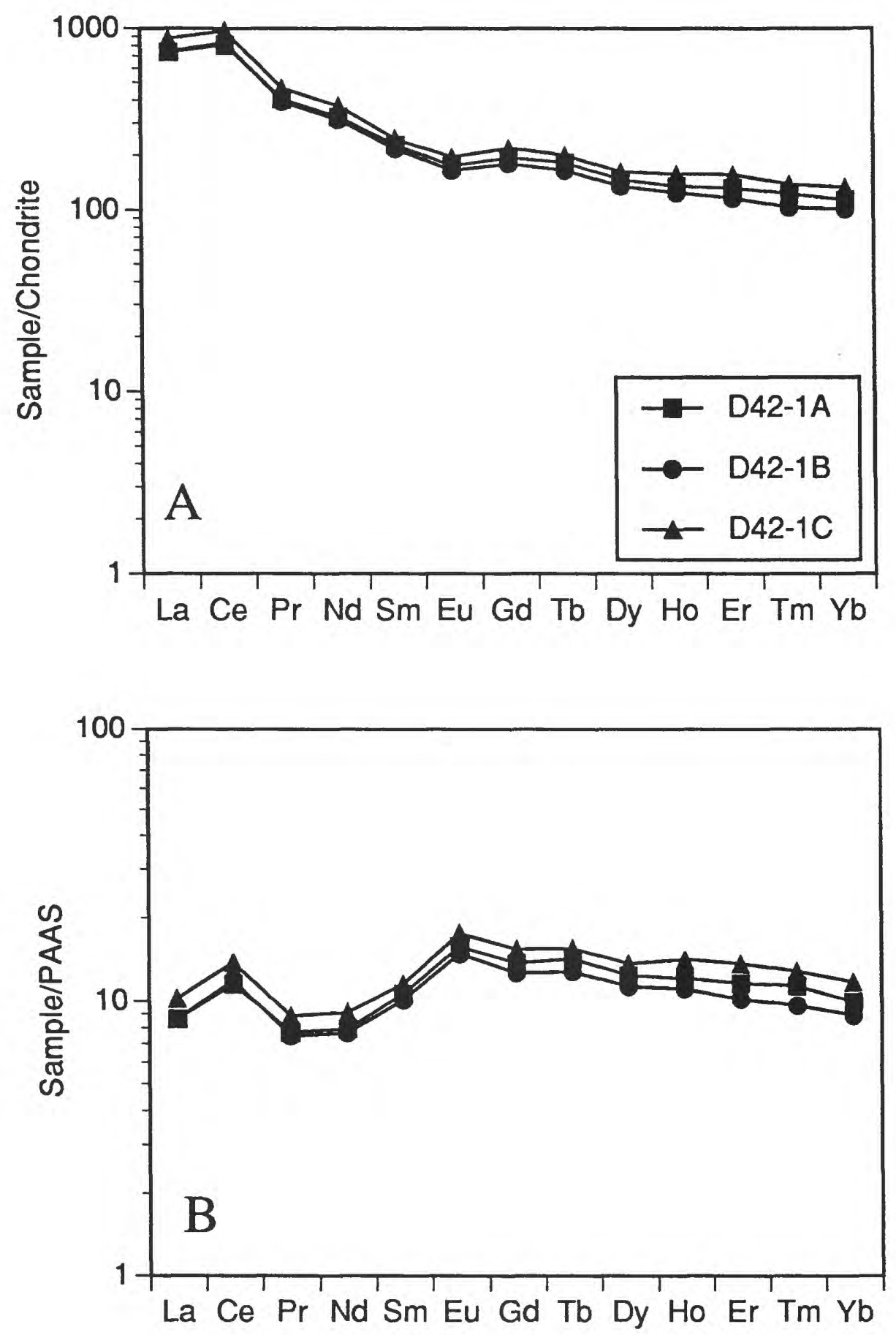

Figure 17. REE plots of crust samples from D42-1, Seth Guyot: (A) Chondrite normalized, and (B) PAAS normalized 

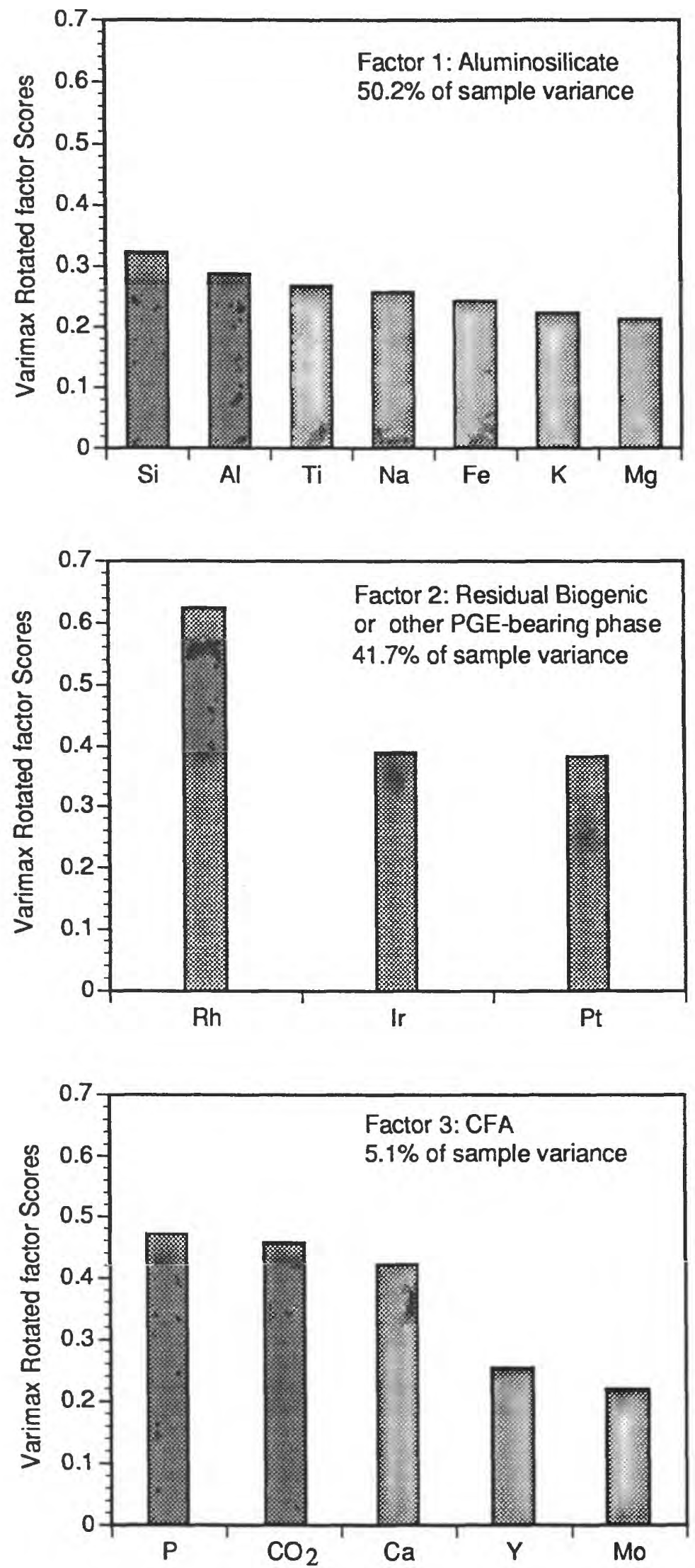

Figure 18. Three of five Q-mode factors for 46 bulk crusts (see figure 19 for other two). Factor scores between 0 and 10.201 are not included because random noise makes it difficult to resolve the orientation of the factor to within $10^{\circ}$ of an absolute direction in variable space. 

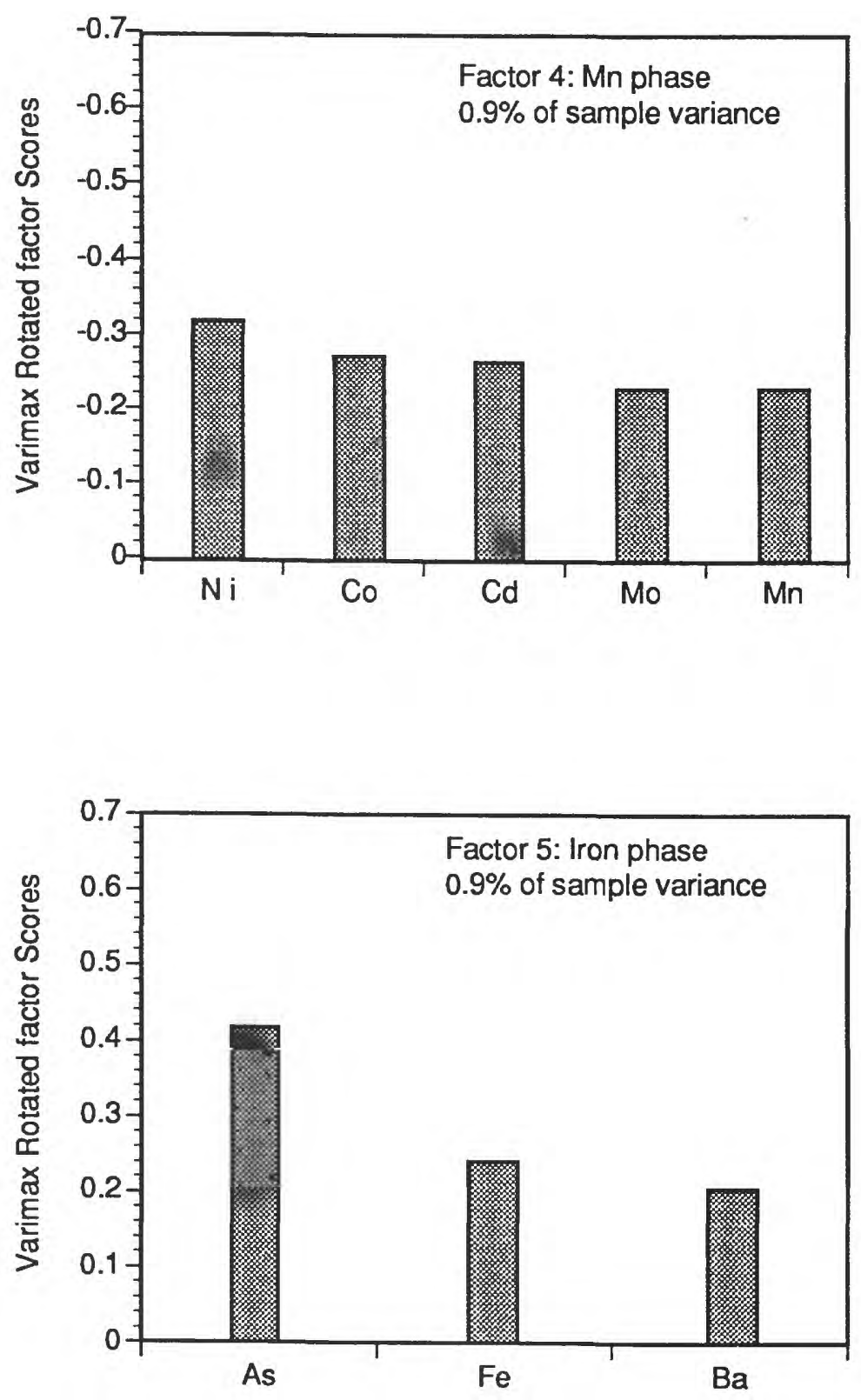

Figure 19. Two of five Q-mode factors for 46 bulk crusts (see figure 18 for other three). The five factors account for $98.8 \%$ of the dataset. 